\title{
بحث عن.
}

\section{القانوز الصحي السعودي ما بيـن مرحلة الإنشاء والرقابة الداخلية والخارجية بالمملكة والنظام الدولي}

\author{
| - 1قرم بنا \\ د/ عبير حملي محمل حسن \\ أستاذ مساعد - قسم القانون - كليه الأعمال - رابخ \\ جامعه الملك عبل العزيز
}





\section{خطة البحث}

مقدمة:

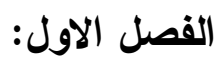

المبحث الاول: نظام المؤسسات الصحية الخاصة:

المطلب الاول:الأحكام العامة:

المطلب الثاني:ترخيص فتح المؤسسات الخاصة

المطلب الثالث: الثروط و المتطلبات الخاصة بكل مؤسسة صحية

المبحث الثاني:المؤسسات الصحية (العيادات و المجمعات الطبية)

المطلب الاول: شروط ترخيص العيادة الخاصة:

المطلب الثاني: ضو ابط وشروط انشاء هذه المر اكز :

المطلب الثالث: انتهاء الترخيص للمؤسسة الصحية الخاصة

المطلب الر ابع:اجر اءات التقاضي امام اللجان:

الفصل الثاني: نظام مزاولة المهن الصحية الصادر بالمرسوم الملكي رقم 9 هـ

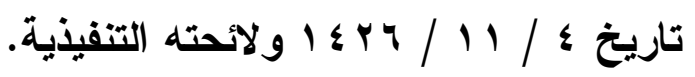

المبحث الاول:الترخيص بمزاولة المهنة الصحية للممارسين الصحيين

المطلب الاول: شروط التزخيص بمز اولة المهن الصحية

$$
\text { المطلب الثاني:مدة التزخيص }
$$

$$
\text { المطلب الثالث:و اجبات الممارس الصحي }
$$

المطلب الر ابع: واجبات الممارس الصحي تجاه المرضى

المبحث الثاني:حالات جواز افثـاء السر المهنــي للممارس الصحي. 
المطلب الاول :حالات الافثـاء تحقيقًا للمصلحة العامة. المطلب الثاني:محظور ات تتعلق بالاطباء فقط من الممارسين الصحيين المطلب الثالث:المسؤولية المهنية للممارس الصحي المبحث الثالث:المسؤولية الجزائية للممارسين الصحيين. المطلب الاول:المسؤلية الجزائية للطبيب المطلب الثاني:المسؤلية التاديبية المبحث الر ابع:التحقيق والمحاكمة. المطلب الاول:اجر اءات التحقيق و المحاكم

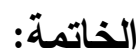
: النتائجج التوصيات: المر اجع: 


\section{مقدمة}

يقاس قدم الأنظمة الصحية بقدم المجتمعات التي نشأت فيها هذه الأنظمة، ففي كل المجتمعات نشأت أنظمة لرعاية المرضى و التعامل مع الألم و العلة. وقد

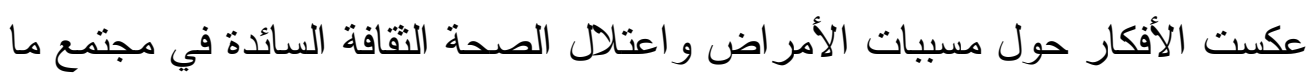
من ناحية بالإضافة إلى درجة تطور هذا المجتمع من ناحية أخرى. ومن ثم، فقد

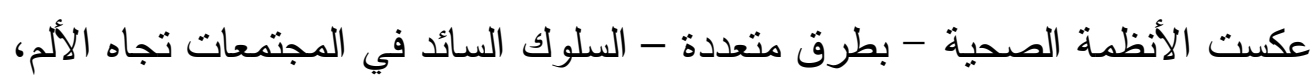
و المرض، و الوفاة، و الصحة. إلا أن درجة التطور الاجتماعي و الاقتصادي و العلمي في أي مجنمع قد لعبت دوراً هاماً في الطريقة التي يعمل من خلالها النظام الصحي

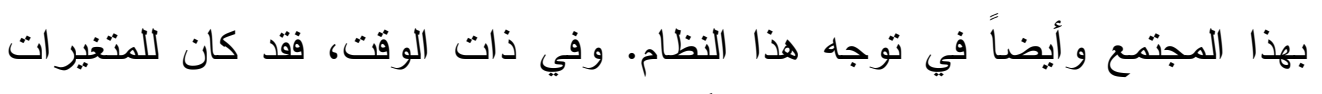

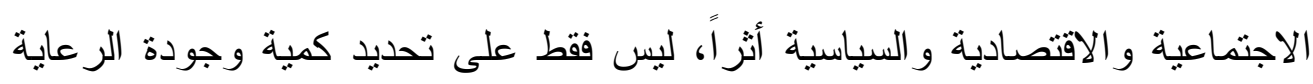
الصحية المقدمة، و إنما أيضاً على توجه النظام الصحي وخصائصها.

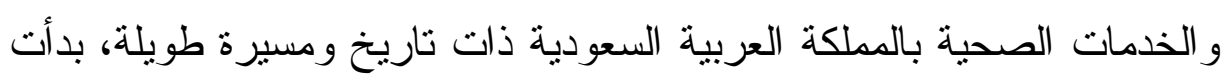

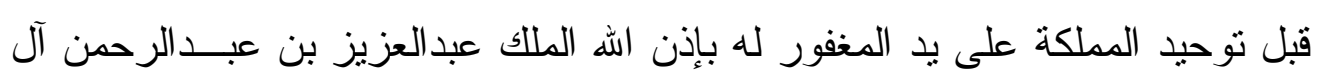

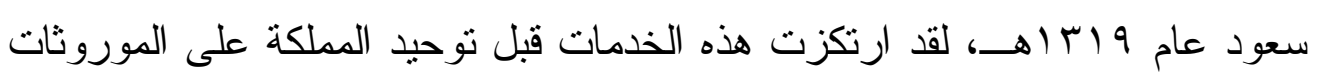

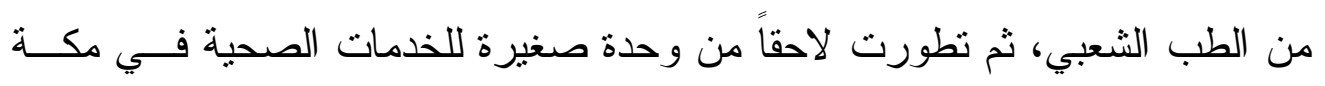

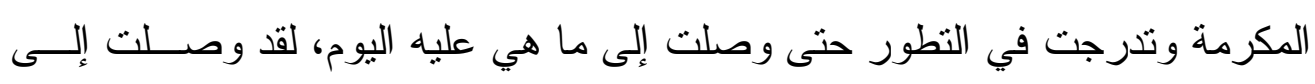

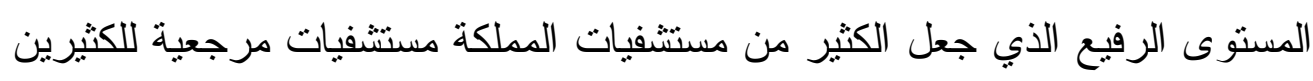

$$
\text { من مو اطني الدول الثقيقة المجاورة و الدول الصديقة }
$$

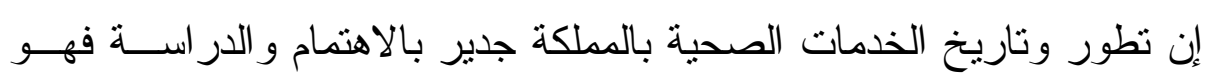

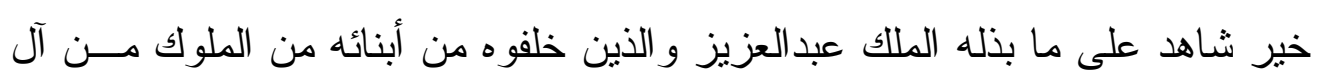
سعود من جهد كبير ورعاية كريمة حتى وصلت الخدمات إلى ما هي عليه اليوم.

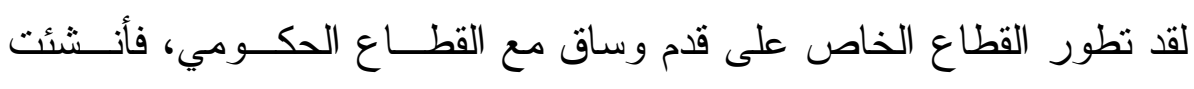
المستشفيات الخاصة التخصصية وفق ضو ابط وزارة الصحة ورقابة المديرية العامة

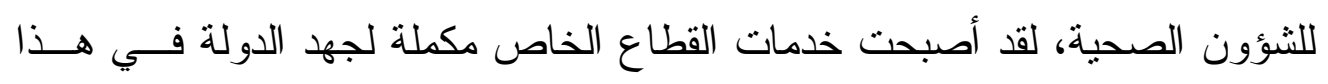

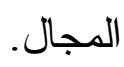




\section{النفمسل الأول \\ المبسحث الأول المول \\ نظام المؤمسعسات المسحية المخاصسة}

\section{المطلب الأول: \\ الأحكام العـامهة:}

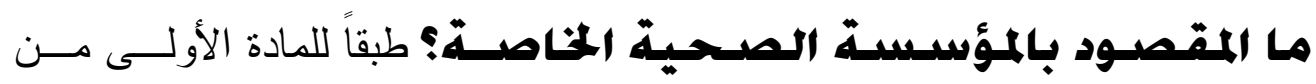
نظام المؤسسات الصحية الخاصة أن المؤسسة الصحية المغاهـة هي (1):

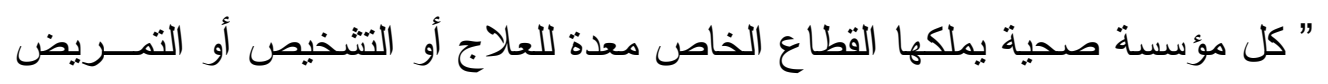

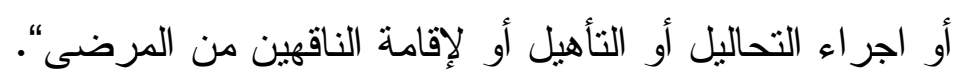

بتضـح من هذا النص أن المؤسسات الصحية التابعــة للأثـــخاص المعنويـــة

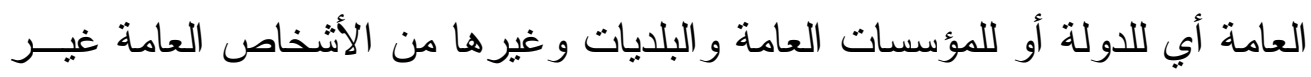
خاضعة للنظام المؤسسات الصحية الخاصة (r).

\section{تشعهل المؤسسسات المسحية اللخاهسة ما يلي:}

المسبـتشـفى: وتأتي على رأس المؤسسات الصحية من حيث الأهمية، وهي كـلـ

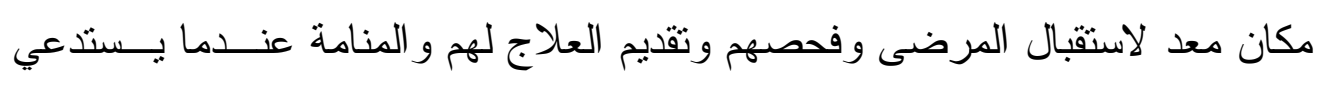
وضعهم الصحي ذلك.

الجمهـع الطبي العـام: وهو كالمستشفى إلا أن النظام اثترط أن يوجد فيه ثلاث

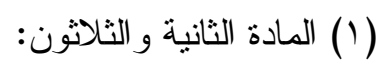

يصدر الوزير اللائحة التنفيذية لهذا النظام خلال تسعين يوماً من تاريخ نشره فــي الجريدة الرسمية.

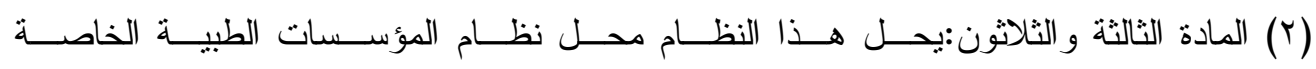

$$
\begin{aligned}
& \text { الــصادر بالمرســوم }
\end{aligned}
$$

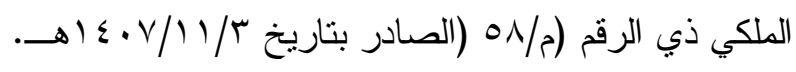


اختصاصات طبية مختلفة على الأقل احدها يجب أن يكون اما الجر احة أو الأمر اض الباطنية أو امر اض النساء و الو لادة أو تخصص الأطفال أو طب الأسرة. الجمهمع الطبي المتتخصسص: وهو عبارة عن مجمع عيادات تخـصص طبـي

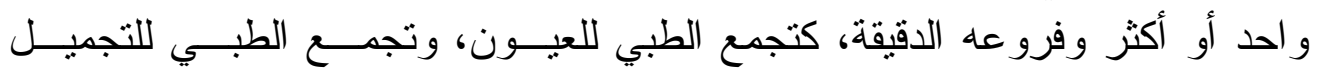
و غير ها.

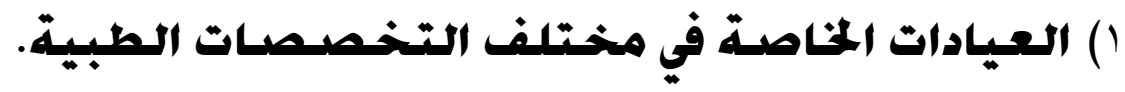
r) مـكز الأشـعة: لإخذ الصور بالأشعة أو العلاج بالأشعة. r) المختبر الطبي: للفحوص المخبرية. مركز جر احة اليوم الواحد: مخصص لإجر اء عمل طبي مثل العمليـات الـصنيرة و المتوسطة على أن يخرج المريض في اليوم نفسه الذي دخل فيه.

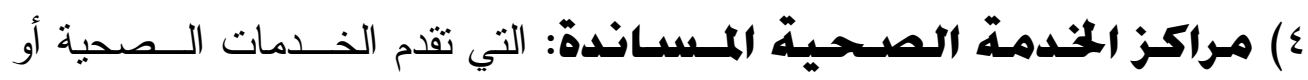
الفنية المتممة كمر اكز العلاج الطبيعي ومحلات النظار ات الطبيــة ومحــلات بيـع الأطر اف الصناعية.

0) مـراكـز خـدمات النقـل الاسـعـافي: وهي التي تتــولى النقـلـ الاســعافي

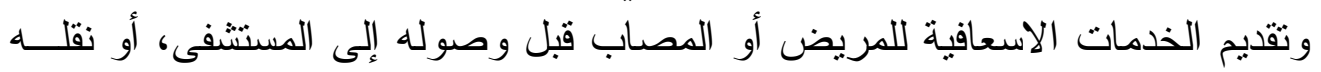
من مؤسسة صحية إلى أخرى.

\section{ملكية المؤسسسات المسحية الملاصسة والاشـراف عليها:}

كل المؤسسات الخاصة ما عدا المستشفيات يجـب أن تكـــون مملوكــة مــن السعوديين ما لم تكن هذه المؤسسات في احدى المناطق النائية المحددة في اللائحـــة التنفيذية لنظام المؤسسات الصحية.

ويشنرط في ماللك العيادة أن يكون طبيباً (سعودياً) متخصصاً في طبيعة عمل العيــادة

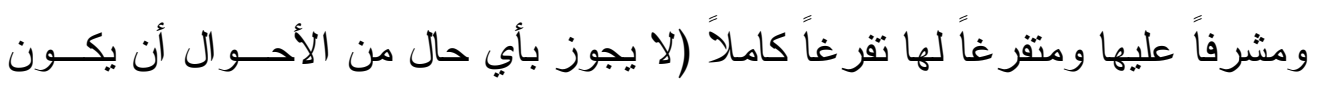


مالك العيادة أو المشرف عليها غير سعودي)(')

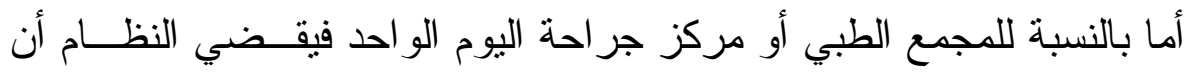

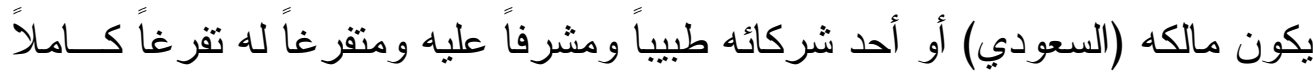
ما لم تكن المؤسسة تقع في المناطق النائية، مما يعني أنه في المناطق النائية يجـــوز أن يكون مالك المجمع و المشرف عليه غير سعودي.

ويشترط في المختبر أو مركز الأشعة أن يكون مالكه (الـسعودي) أو أحسـد

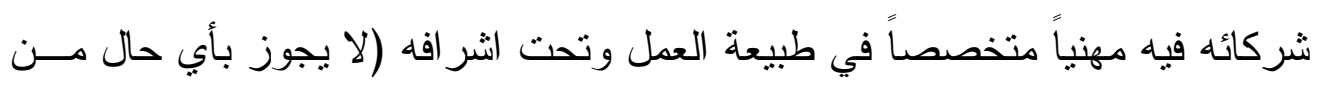
الأحو ال أن يكون ماللك المختبر أو مركز الأشعة أو المشرف عليهما غير سعودي). أضف الى ذلك وجوب أن يكون لكل مؤسسة صحية خاصة مشرفاً فنيــاً متخصــصاً في طبيعة عمل المؤسسة يتقر غ لها تقرغاً كاملاً.

بالنسبة للإدارة يشترط النظام في المستشفى الخاص أن يكون مدير ها الطبـي

طبيباً سعودياً مؤهلاً.

أما الادارة العامة للمؤسسات الصحية الخاصة كافة فيجــب أن تكــون مـنـ السعوديين ذوي التأهيل المناسب.

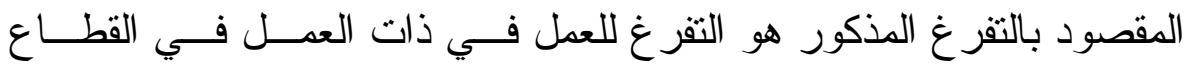
الخاص و الا يعمل في أي مرفق صحي تابع للدولة تحت أي مسمى كان. يكون تشغيل المؤسسات الخاصة بطريقتين اما مباشرة من قبــلـ الأطبـــاء أو المهنيين المتعاقدين وما بطريق غير مباثر عبر التعاقد مع شركة متخصــصة فـي

(1) المادة الر ابعة و الثلاثون: تستمر التز اخيص الصادرة للمؤسسات الصحية الخاصة وفقاً للأنظمة

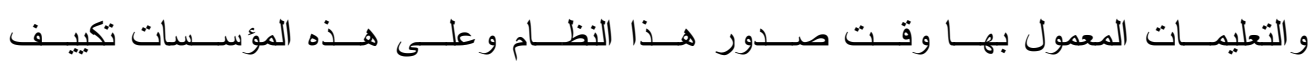

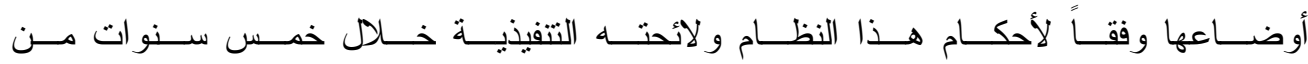

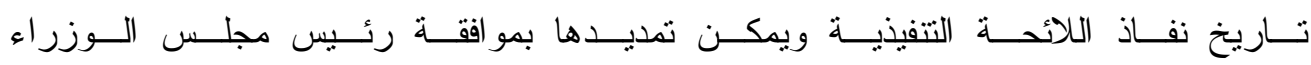

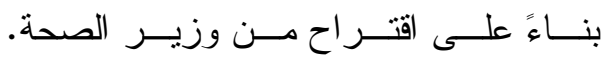


التشغيل الطبي مسجلة أصولاً. يشترط لتملك غير السعودي مؤسسة صحية(مستشفى - مجمــع عيـادات - مركـز لجر احة يوم و احد) في المناطق النائية ما يلي:

أن تكون المؤسسة الصحية و اقعة في النطاق الجغر افي للمنطقة النائية الــذي يحددها وزير الصحة في ضوء الحاجة الثديدة و النقص في التخصصات المطلوبـــة التز خيص لها.

r- مو افقة هيئة الاستثمار الأجنبي بالنسبة للمهني غير السعودي. r- حصوله على ترخيص لمؤسسة صحية و احدة فقط. ع - بالنسبة للمهني غير السعودي يجب أن يكون هو المالك للمؤسسة ومشرفاً عليهـــا ومتفر غاً عليها ومتقر غاً لادارتها تفرغاً كاملاً.

نشير إلى أنه يسري على فرع المؤسسة الصحية من شروط ما بسري على المؤسسة الرئيسية. الثروط الو اجب تو افرها في مباني المؤسسات الصحية الخاصة هناك معايير وشروط عامة يجب نو افرها في مبنى المؤسسة الصحية هذه الـشروط هي (1)

موقع مناسب يسهل الوصول اليه مع وجوب تو افر موقف للسيار ات يتتاسب مع حجم المؤسسة.

تو افر منطلبات السلامة العامة ومكافحة الحريق وتدرب العاملين على طرق المكافحة وكيفية التسبيق مع الدفاع المدني.

(1) البريك، سرى (...r.): (دور القطاع الصحي الخاص في تطبيق نظام الضمان الصحي التعاوني)، ورقة مُقَِّّة في ندوة الضمان الصحي التعاوني المنعقدة بالغرفة التجارية الصناعية

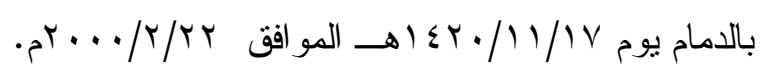


توفير مكان مناسب لملفات المرضى.

تو افر خط هاتفي أو أكثر بحسب حجم المؤسسة.

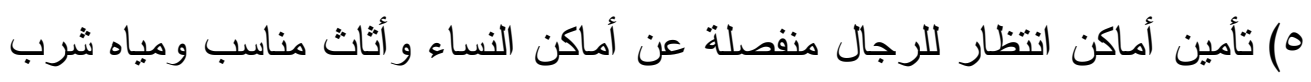
باردة ودور ات مياه كافية ونظيفة.

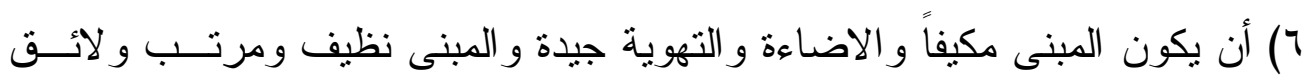
لاستقبال الناس.

V) وضع لوحة رئيسية على مدخل المؤسسة تبين اسمها وتخصصها ومو اعيد العمل ووضع لو ائح استرشاديه داخل المؤسسة.

من المستحسن أن يشتمل المبنى على مداخل ومخار ج مصممة للمعاقين. 9) تو افر المعدات و الأثاث و الأجهزة الطبية لكل مؤسسة وفق الشروط الخداصة التهي ينص عليها النظام. بالإضـافة إلى هذه الثروط العامة يجب أن تلتزم المؤسسات الصحية بنظام مكافحـــة العدوى و التخلص من النفايات الطبية حسب الثروط التي تقررها الوزارة. كما يجب أن يتو افر في كل مؤسسة نظام معلومات يلائم حجم المؤسسة وأن يتـــو افر كحد أدنى ما يلي:

لائحة داخلية تتعلق بالعمل و العمال وحقوقهم وو اجباتهم. نظام حديث لتسجيل المو اعيد و الاستعلام. وجود النماذج و السجلات الطبية و الاحتفاظ بملفات المرضــى لمــدة خمـس المس

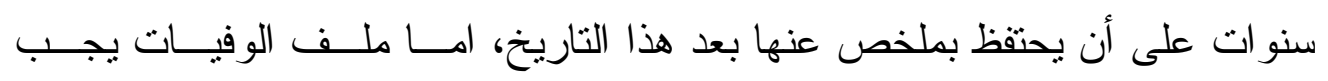
الاحتفاظ به طو ال مدة عمل المستشفى. دفاتر للوصفات الطبية:(1)

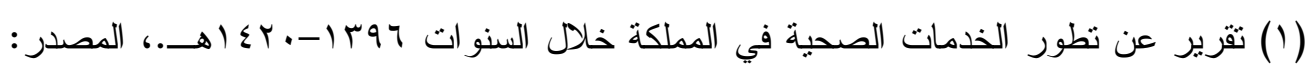

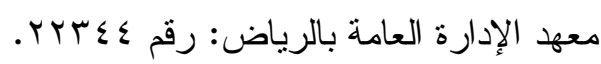




\section{المطلب الثناني:}

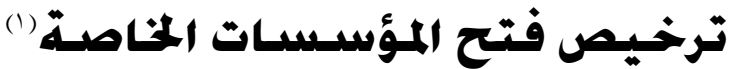

تمنح المؤسسات الصحية ترخيصاً بإنشائها أو تشغيلها لمدة خمـس ســنو ات

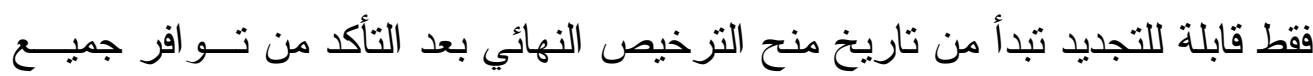
الثروط و المتطلبات التي ينص عليها نظام المؤسسات الصحية و لائحته التنفيذية:

(شروط عامة وشروط متعلقة بالمبنى وأخــرى بالكــادر البـشري ومنهــا

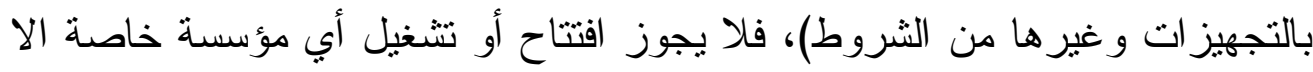
بعد استكمال كافة الشروط المطلوبة.

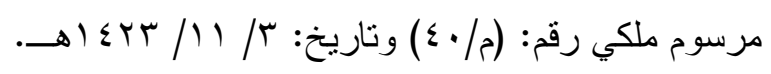

بعون الله تعالى، نحن فهر بن عبد العزيز آل سعود (ملك المملكة العربية السعودية) بناء على المادة (السبعين) من النظام الأساسي للحكم، الصادر بالأمر الملكي رقم (أ/.9) وتاريخ لهاريخ . وبناء على المادة (العشرين) من نظام مجلس الوزر اءه، الصادر بالأمر الملكي رقم (أ/ז آ) وتاريخ

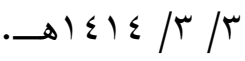
وبناء على المادتين(السابعة عشرة) و (الثامنة عثرة)من نظام مجلس الثنورى، الصادر بالأمر

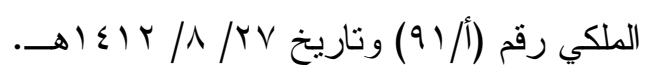

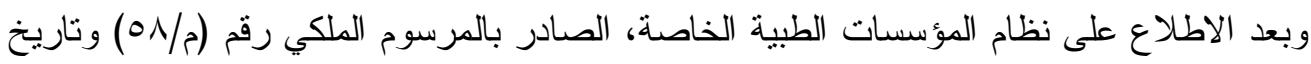
.

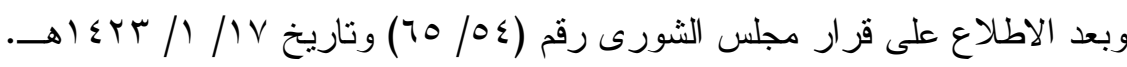

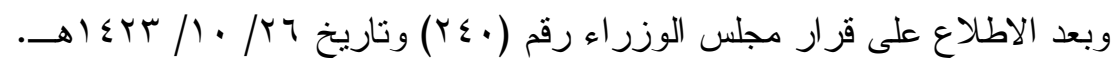
رسمنا بما هو آت:

أو لاً: المو افقة على نظام المؤسسات الصحية الخاصة، بالصيغة المر افقة. ثانياً: على سمو نائب رئيس مجلس الوزر اءو و الوزر اء كل فيما يخصه تتفيذ مرسومنا هذا.

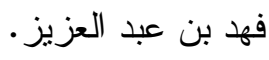

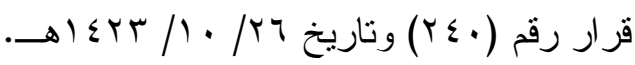


ان المستتفيات تمنح رخصة بموافقة الوزير ، أما المؤسسات الصحية الأخرى تمــنح الرخصة بمو افقة مدير الثؤون الصحية بالمنطقة أو المحافظة التي يقع في دائرتهـــا

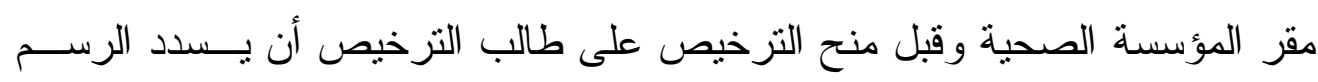
المتوجب وفق الجدول الوارد باللائحة التنفيذية. تصنيف المؤسسات الصحية: تصنف المؤسسات الصحية إلى عدة درجات وفقاً للمعايير و الثروط الموضوعة مــن قبل لجنة مشكلة بقر ار من وزير الصحة تتكون من: ممثل عن وز ارة الصحة. ممثل عن مجلس الضمان الصحي. مدل عن الهيئة السعودية للتخصصات الصحية. ممنل عن الغرف التجارية و الصناعية. بالاضافة إلى ثلاثة أعضاء يختارهم وزير الصحة من ذوي الخبرة. يتم تصنيف المستشفيات ومر اكز جر احة اليوم الواحد و المجمعات الطبيــة المـشتملة

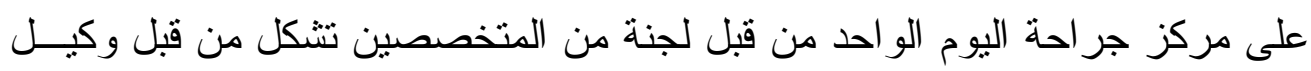

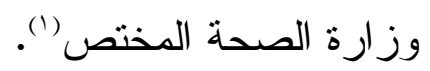
أما المؤسسات الأخرى فيتم تصنيفها من قبل لجنة من المختصين تشكل بقــرار مــن مدير الشؤون الصحية المختص (r). تحديد متوسط أسعار الخدمات الصحية إن أسعار الخدمات الصحية مقيدة بما

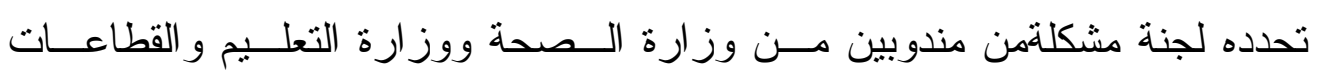

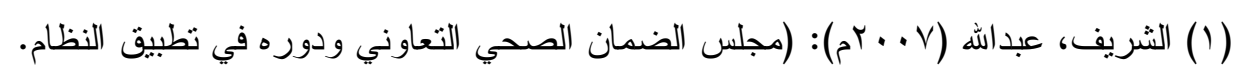

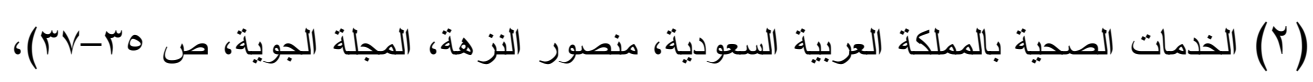

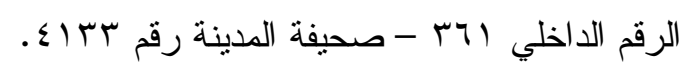


العسكرية وشركات التأمين الصحي ومجلس الــضمان الــــي ومجلـس الغــرف التجارية و الصناعية، تقوم هذه اللجنة بتحديد منوسط الأســعار للخــدمات الــصحية وير اجع هذا المنتوسط كل ثلاث سنوات، و على المؤسسات الصحية الالتز ام بمتوســط

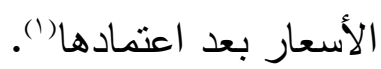

توظيف الأطباء وغير هم من الممارسين الصحيين يعرّف الممارس الــصحي بأنه كل من برخص له بمز اولة المهن الصحية التي تشمل الفئات الآتية (r)" - الأطباء البشريين و أطباء الأسنان و الصيادلة و الفنيين الــصحيين فـي (الأثــعة،

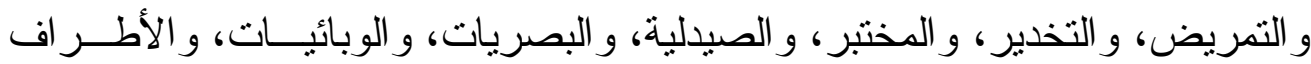
الصناعية، والعلاج الطبيعي، ورعاية الأسنان وتركيبها و التصوير الطبقي، و العــلاج النووي، و أجهزة الليزر، و العمليات) و الأخصائيين النفسيين و الاجتماعيين، و اخصائي التغذية و الــصحة العامــة،

(1) الحيدر، عبدالمحسن ومحمد التزكي (ץ (ب): نظام الضمان الصحي التعاوني في المملكة العربية السعودية (بحث ميداني) الرياض معهد الإدارة العامة.

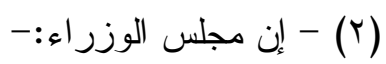

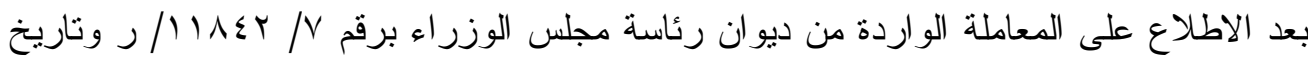

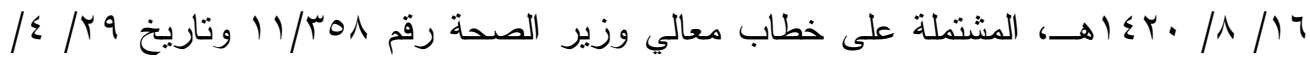
1 إهـ بشأن مشروع نظام المؤسسات الصحية الخاصة.

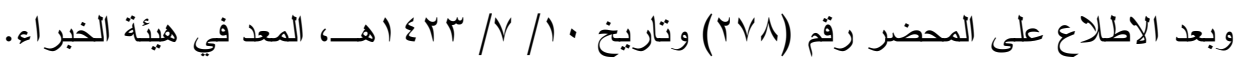

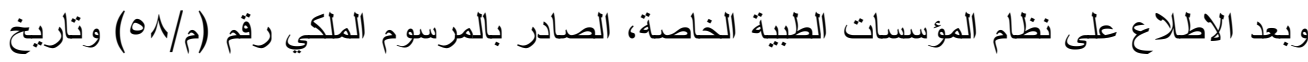

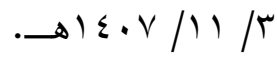

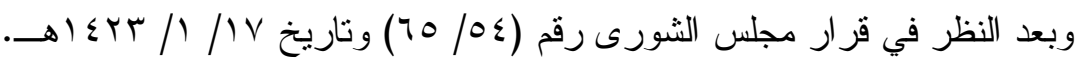

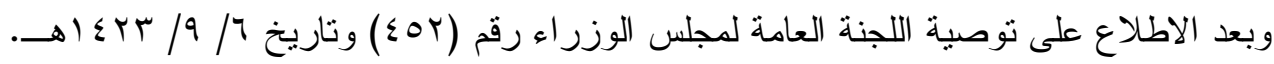
يُقرِّر المو افقة على نظام المؤسسات الصحية الخاصة بالصيغة المر افقة. وقد أعد مشروع مرسوم ملكي بذلك صيغته مر افقة لهذا. رئيس مجلس الوزراء. 
و القبالة، و الاسعاف، ومعالجة النطق و السمع و التأهيل الحرفـي و العــلاج الحرفـي

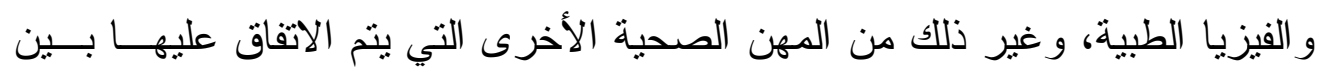
وزيري الصحة و الخدمة المدنية و الهيئة السعودية للتخصصات الصينة الصحية.

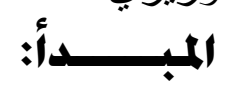
لا يجوز لأي مؤسسة صحية أن توظف أي ممارس صحي الا بعد حـصوله

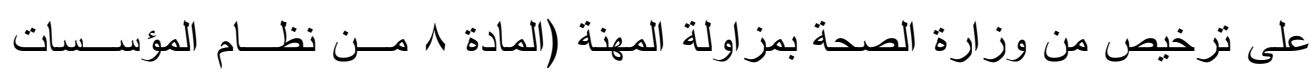

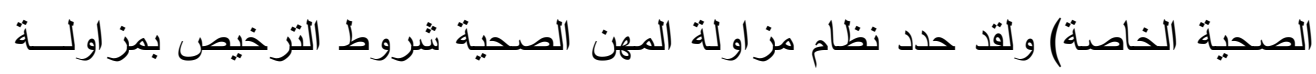
المهني الصحية وهي: الحصول على المؤهل المطلوبة للمهنة (مثنلاً شهادة طب إذا كـــان طبيبــاً - شــــادة صيدلة إذا كان صيدلياً... الخ) ('). أن يكون قد أمضى الممارس الصحي فترة تدريبه. أن يكون مسجلاً لدى الهيئة السعودية للتخصصات الهمان الصحية. ألا يكون محكوم عليه بجريمة مخلة بالثرف و والأمانة.

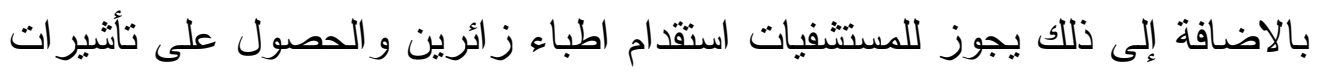

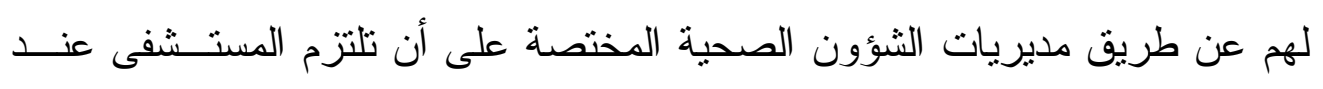

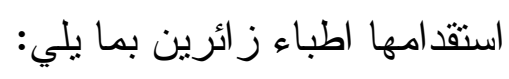
تحمل مسؤولية كاملة عن أي خطأ طبي قد يرتكبه الطبيب الزائر .

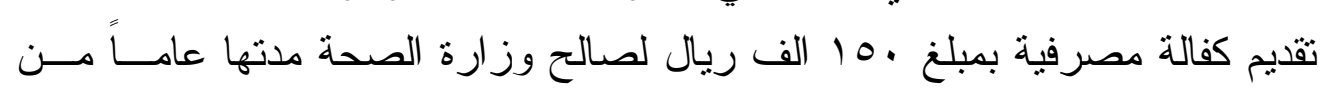
تاريخ المو افقة على الاستقدام. عدم الاعلان عن الطبيب الزائر الا بعد الحصول على مو افقة الاستقدام.

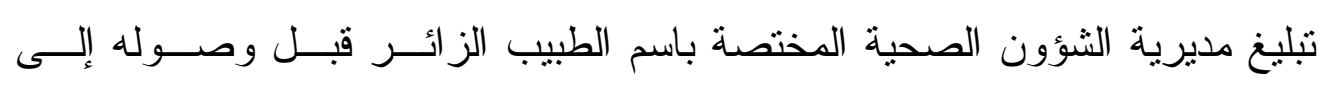

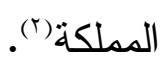

(1) تتظيم الخدمات الصحية في المملكة العربية السعودية، العماري، رقم //آب ن ر، ومعهد

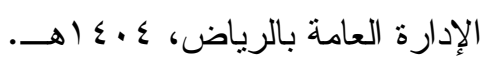

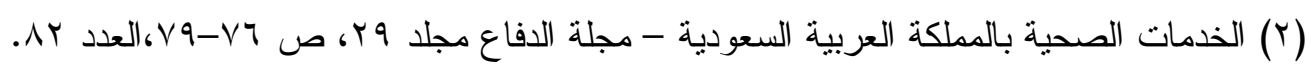




\section{المطلب الثالث}

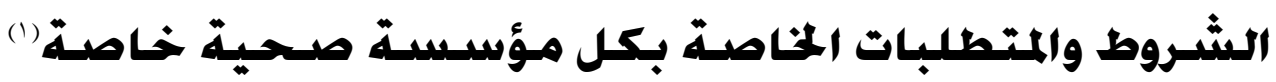
أولا.... المسدتشثـفيات.

ا- الثروط المتعلقة بعدد الأسرّة: يجب ألا يقل عدد الأسرّة عــن ثناثـين بالنـسبة للمستشفى المرخص لها بأكثر من تخصصين، وعن عشرين للمستشفى المرخص لها بتخصصين فقط، و عن عشرة أسرّة للمستثفى المرخص لها بتخصص وله واحد.

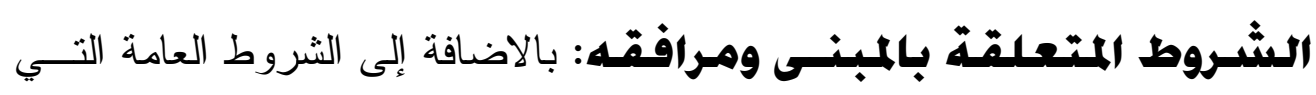
سبق ودرسناها الو اجب تو افر ها في مباني كافة المؤسسات الصحية الخاصـــة هنــالك شروط خاصة يجب نو افر ها في مبنى المسنتفى على الوجه الآتي: تطابق المبنى مع أنظمة البناء في المنطقة ومو اصفات وزارة الصحة. توفر وسائل السلامة في المبنى كمخارج الطو ارئ ولوحات ارشادية لها، وطفايـات الحريق و اجهزة الانذار .

ج. ترنيب الأقسام بصورة علمية و اتساع الممرات وضرورة وجود لوحات ارشــادية

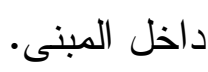
د. تأمين مصدر صحي للمياه الباردة و الساخنة في مر افق المستشفى. هــــ توفر مصدر احتباطي للكهرباء (مولد كهربائي خاص بالمؤسسة) بقـــوة كافيــة لتشغيل الأقسام الرئيسية بالمستشفى.

و. نوفر الثروط الصحية و الفنية في التمديــدات الــصحية، وأن تكــون تمديـــات

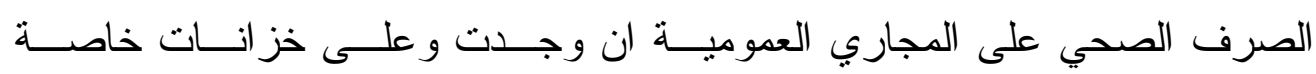
بالمستشفى.

- نطور الخدمات الطبية بالمملكة العربية السعودية ودور الأجهزة المساعدة رقم

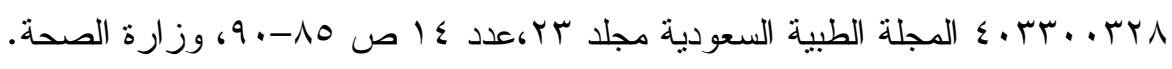


ز • تو افر المصاعد إذا كان المستشفى مؤلف من طابقين فأكثر .

\section{الشـروط المتعلقة بالعـاملين في المستشفهيات ('):}

بالاضافة إلى شرط الترخيص بمز اولة المهن الصحية للممارسين الصحيين في كافــة

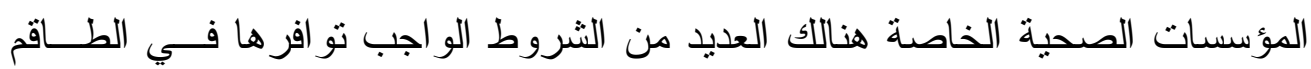
البشري الذي يسيّر أعمال المستشفى، لا سيما المدر اءو والأطباء و الممرضين. بالنسبة لمدير الادارة العامة: يجب أن يكون مدير المستشفى سعودي الجنسية يحمـلـ شهادة جامعية ولديه الأهلية و التدريب اللازمين لادارة المستثفى. لادئ. بالنسبة للمدير الطبي: يجب تعيين أحد الأطباء ليكون رئيساً للأطباء ومسؤو لاً عـنـ العمل الفني المتعلق بمهنة الطب وبالضرورة يجب أن يكون من السعوديين. بالنسبة لرئيسة الممرضين: يجب تعيين رئيسة للتمريض لديها الأهلية و الخبـرة فــي

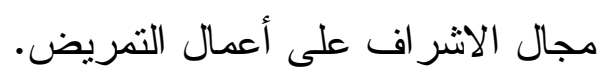
بالنسبة للأطباء: يجب وجود عدد كاف مــن الأطبــاء الاستـشاريين و الاخــصائيين و المقيمين حسب التخصص كما يجب تو افر عدد كاف من أطباء التخــدير للأقــسام الجر احية، و أطباء أطفال في اقسام الو لادة.

توفير عدد كاف من الفنيين العاملين على الادوات الميكانيكية الطبية كعمال المختبــر

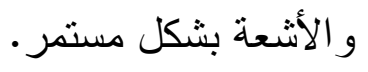

باللنسبة للممرضين: يجب توفير عدد كاف من الممرضين و الممرضات لتغطية كافــة

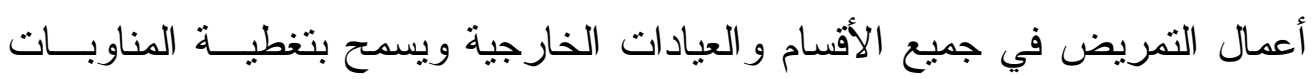

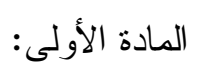

تدل الكلمات و العبار ات الآتية حيثما وردت في هذا النظام على المعاني الددونة أمامها ما لم يقتض السياق خلاف ذلك:

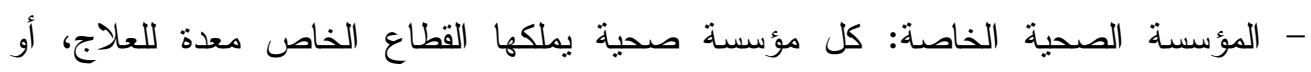

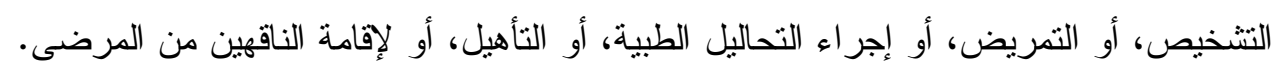


أقسام وخدمات المسنشفى يجب أن تشمل كل مسنشفى خاصة حسب التخصص علـى عدة أقسام وأن تكون مجهزة حسب قو ائم وز ارة الصحة.

أي مستشفى خاصنة يجب أن تتضمن على الأقل الأقسام التالية تقدم فيهــا خـدماتها الصحية.

أو لاً: الخدمات الطبية، التي تقدم في الأقسام التالية:

قسم الطوارئ: هو القسم الذي تستقبل فيه الحالات الطارئة من مرضــى أو ضـــايا

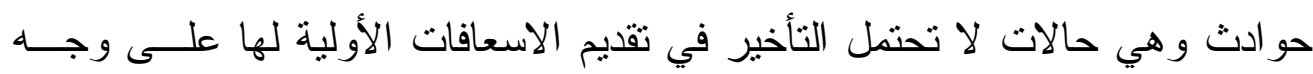
السرعة يلتزم قسم الطو ارئ بما يلي (1): استقبال أي حالة اسعافية. توفير طبيب اسعاف و احد على الأقل و عدد كاف من الممرضين. تأمين سيارة اسعاف واحدة على الأقل. الاستعداد لتقديم خدمات طبية خارجية عند الضرورة. r) العيادات الخارجية: تخصص لاستقبال المر اجعين من المرضى ضـــن أوقــات الدو ام العادي. r) المختبر : وله شروط خاصة يجب أن نتو افر فيه سنذكرها لاحقاً. ع) قسم الأشعة: يجب أن يتو افر فيها الثروط الفنية و التجهيز ات الخاصـــة بعيــادات

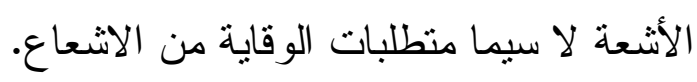

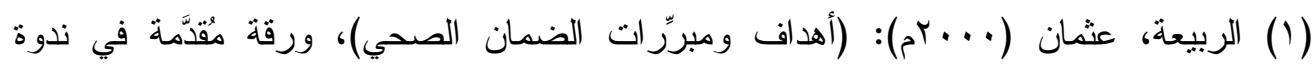

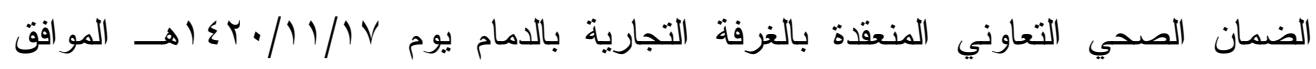
$\cdot$. $r \cdot r / r t$ 
0) صيدلية: يدير ها صبدلي مجاز ومرخص له وتطبق بـشأنها أحكــام الــصيدليات الخاصة.

7) جناح العمليات: ويوجد فيه عدة أقسام جر احة ويجب أن يشمل على التالي: مدخلاً خاصاً للعاملين ومكاناً لتغيير الملابس. مكاناً منفصلاً لتعقيم الأيدي. غرفة تحضير أجهزة العمليات (أجهزة تعقيم عاجل). غرفة تخدير للمستشفيات التي يكون فيها عدد الأسرة مئة فأكثر.

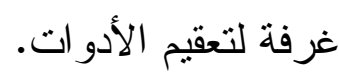

(V جناح التوليد: للمستشفيات التي فيها قسم توليد على أن تشمل غرفتين على الأقـلـل

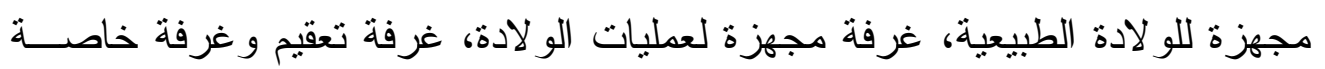
بالأطفال حديثي الو لادة، وحاضنات كافية للأطفال غير مكتملي النمو . ^) أجنحة الاقامة: على أن ير اعى فيها. "وجود غرف للمرض ذات مساحة كافية وفقاً للمتعارف عليــه ومدهونـــة بطــلاء

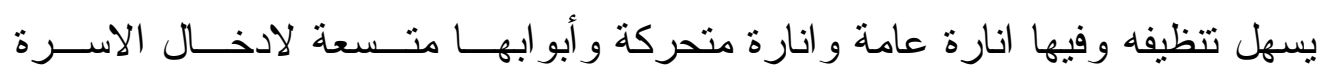

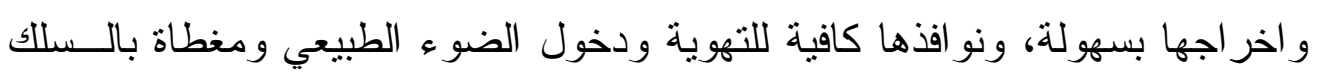

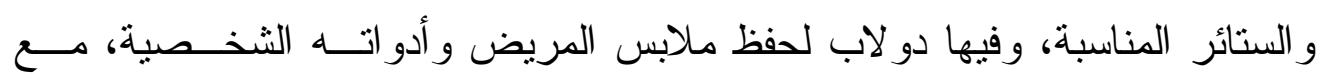
ضرورة وجود غرفة أو خز انة عامة للأمانات.

كما يتوجب أن يكون السرير قابل للتحرك يدوياً ومخصصاً له طاولة للطعام

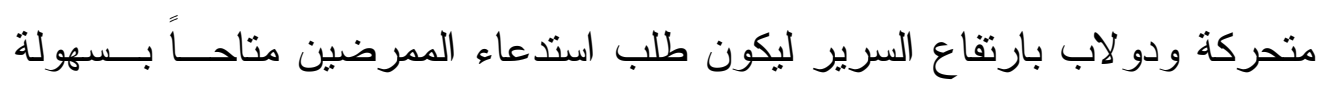
للتمريض. أن يوجد في كل دور صالة جلوس واحدة على الأقل مفروضة وفقاً للمتعارف عليـهـ 


$$
\text { (وفيها كتيبات ومجلات ونشر ات نوعية)(') }
$$

عدد من الأسرة مخصصة لحالات العناية المركزة لا تقل عن · (\% مـن مجمـوع الأسرة، ويتم تجهيزه بالاثاث و التجهيز ات الآلازمة. يخصص لكل مريض بالعناية المركزة ممرضة على مدار ع ساعة. يتم الاشر اف على القسم من قبل طبيب مختص يتبع تعليمات رئيس قسم التخـدير أو رئيس قسم الباطنية بالمستشفى.

• (1) قسم العزل: وهو القسم التي يستقبل حالات الأمر اض المعدية، يخــصص فيـــ غرفة للعزل بر اعى فيها التالي:

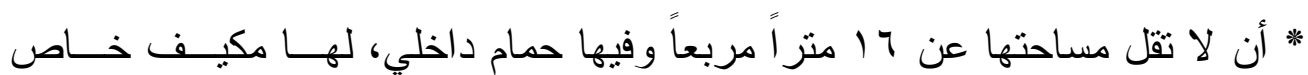
منفصل ويكون نظام التهوية بها بسمح بدخول الهو اء من الخــار ج ولـيس العكـس. و الأهم من ذلك كله أن تكون غرفة العزل مفصولة عن باقي أقسام المستشفى وبهــا

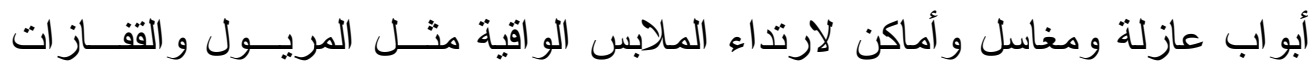
و غطاء الر أس وما شابه.

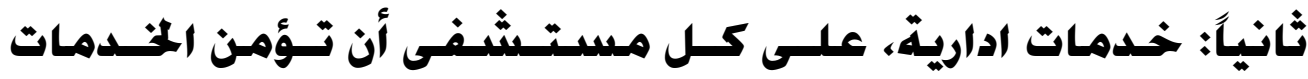 الادارية التتالية (r)}

قسم مستقل الادارة: يمكث فيه المدير ومساعديه وموظفي الادارة و المحاسبة. مكتب الاستقبال: يقع على مدخل المستشفى يشرف عليه موظف يتكلم اللغة العربيـــة حاصل على الشهادة الاعدادية على الأقل وقادر على ارشاد زوار المسنشفى.

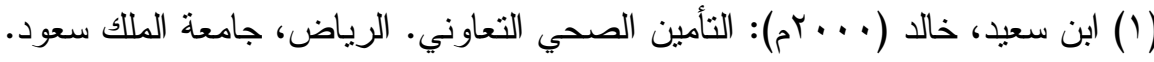

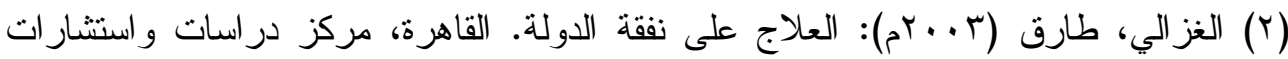
الإدارة العامة. 
مكتب المو اعيد: لتحديد مو اعيد المر اجعة للمرضى.

قسم السجلات الطبية: يقوم هذا القسم باعداد ملف لكل مــريض دخــل المستـشفى،

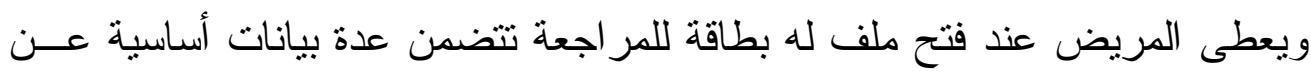
المريض على أن يوفر مكان مناسب و العمالة اللازمة المؤهلة لحفظ الملفات الطبية.

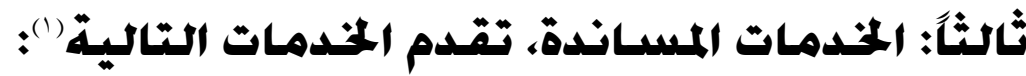

التغذية: على المستشفى تأمين مطبخ تتو افر فيه كافة الثروط الصحية و الفنية لاعداد الطعام للمرض مع وجوب توفير نظام تغذية ينو افق مع لو ائح وزارة الــصحة فــي مجال التغذية ويجب أن يعين مشرف تغذية مؤهلة فنياً. خدمات الغسيل: تأمين غرفة لغسيل الأغطية و الثر اثثف و الملابس وكيها، وتجهيـز

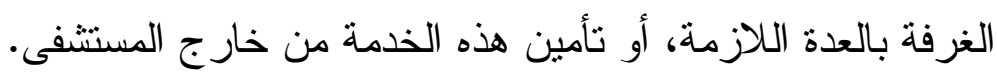
() خدمات النظافة: مهام هذا القسم تقديم خدمات النظافة إلى كافة أقسام المستـشفى

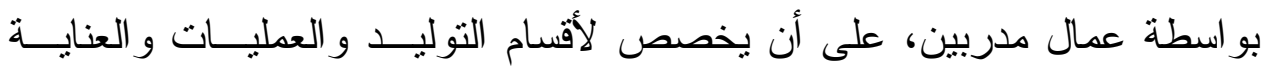
المركزة خدمات تتظيف مستقلة.

من الجدير بالملاحظة أن اللائحة التنفيذية لنظام المؤسسات الصحية الخاصة الزمـــ العاملين بخدمات النظافة و المطبخ و الغسيل قبل توظيفهم أن يستحصلو ا على شـــهادة صحية تثبت خلوهم من الأمر اض المعدية.

r) ثلاجة الموتى:على كل مستشفى تأمين ثلاجة لحفظ الجثث بما لا يقل عن أربعـة

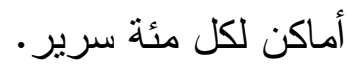

دور النقاهة وتمريض المسنين يمكن أن تؤسس دور النقاهة وتمريض المـسنين امـــا بشكل مستقل و اما كقسم خاص تابع للمستشفى.

(1) الكتاب الإحصائي السنوي، العدد الثامن عشر r.؛؛ (اهـهوزارة المالية والاقتصاد الوطني بالمملكة العربية السعودية. 
شروط الترخيص لدور النقاهة يجب تو افر الثروط التالية للتزخيص بفـتـح وتـشغيل دور النقاهة وتمريض المسنين: الشروط الصحية العامة وقو اعد السلامة. العدد الكافي من الأطباء لا يقل عن طبيب و احد لكل أربعين سريرًا. تجهيز دور النقاهة بكافة الأجهزة اللازمة تز اعي وضع المرض و المسنين، ووســائل التثقيف والتزويج اللازمة و اماكن القيام بالتمارين الرياضية و الصحية الأساسية. r) عدد من الممرضين بمعدل r ممرضين لكل أربعين سريراً على الأقل. ع) مستوى جيد من النظافة و التغذية. علاج المدمنين لاى المستشفيات الخاصة. أتاحت اللائحة التنفيذية لنظام المؤسسات الخاصـــة، للمستـشفيات اســتقبال وعلاج الحالات الاسعافية الخاصة (المدمنين - حالات الصرع) التي إذا تأخر تقــديم

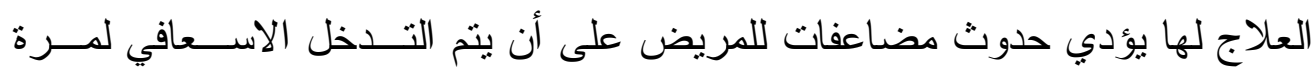

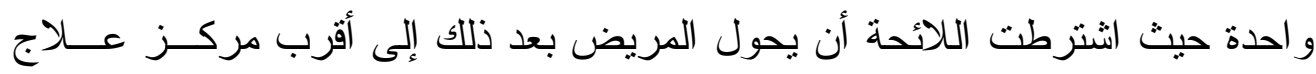

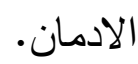

أما اذا ار ادت المستشفى القيام بانشاء قسم شامل لعلاج المدمنين عبر تقنيــة مساعدة المدمن التدريجية على عدم تعاطي المخدر ات كمرحلة أولى. و استكمال علاجه النفس و الاجتماعي كمرحلة ثانية للاقلاع عـن الادمــان فيســح للمستشفى بذلك إذا استكملت الثروط التالية'(1): مو افقة وزير الصحة بعد التأكد من تو افر الثروط المطلوبة لافتتاح القسم.

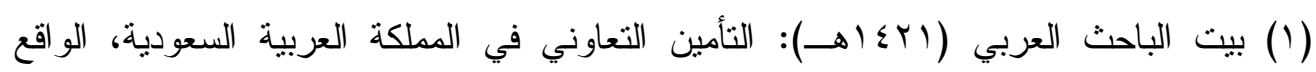

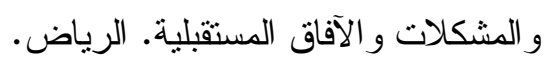


أن يكون المسنتفى يضم جميع التخصصات وليس قسم علاج المدمنين فقط. يتم العلاج في قسم خاص مخصص لهذا الغرض.تو افر عاملين مؤهلين فــي الطــب النفسي و الصحة النفسية ولديهم اختصاص في ذلك طبقاً للمعايير الدولية ولمـــا تــر اه الادارة العامة للصحة النفسية و الاجتماعية على أن ير أس هؤلاء العمال استشاري في الطب النفسي. أن يتو افر في المستشفى مركز اً للعلاج التزفيهي. أن يتو افر في المسنتفى مختبراً يحتوي على أجهزة كثف المخــدر ات و المــؤثرات

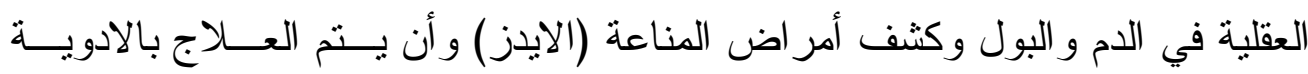
النفسية وليس بالادوية المخدرة، أما إذا كانت حالة المريض تتطلب معالجته بالادوية المخدرة فيجب أن يتم ذلك في مستشفى متخصص بعلاج الادمان مع وجوب از الـــة جميع المو اد والادوات التي قد تشكل خطر اً على المريض. أن ينوفر بالقسم غرف مجهزة لاحتو اء خطورة المريض.

خضوع القسم للتفتيش المفاجئ من قبل الاجهــزة المختـــة فـي الــسلطة العامة.يسمى القسم بقسم التوجيه و التأهيل. الواجب العام الو اقع على كافة المؤسسات

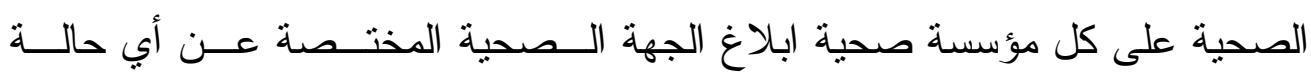
مرضية معدية فور نتخصيها، كما احالة حالات الحجر الصحي للامر اض المعديــة إلى مستشفيات الوز ارة مباشرة و الابلاغ عن ذلك فوراً، تقوم وزارة الصحة باعـــداد

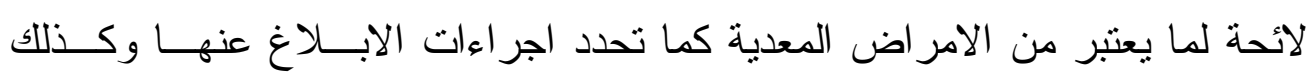

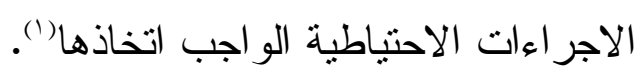

(1) ساعاتي، عبدالإله (991)م): (تطبيق نظام الضمان الصحي في دول مجلس التعاون -

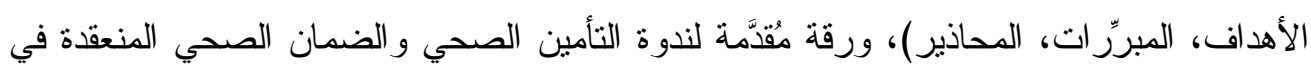

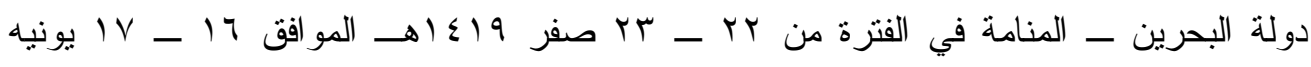




\section{المبسحث الثناني \\ المؤسسعات المسحية

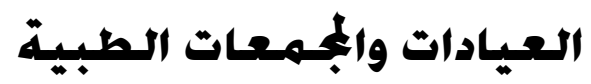 \\ المبطب الاول \\ شـروط ترخيص العبيادة الملاصسة:}

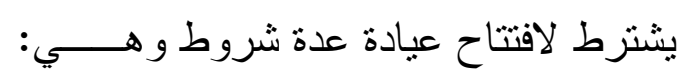

أن يكون مالك العيادة طبيباً سعودياً مصنفاً كطبيب ممارس في نفس العيادة المطلوب التزخيص لها، وترخيص مهني ساري المفعول. أن يتو افر فيها المر افق التالية(1):

المر افق و الثروط العامة التي تتو افر في كافة المؤسسات الصحية الخاصـــة و التــي درسناها سابقاً.

غرفة مخصصة للكثف على المريض لا تقل مساحتها عن 1 ا متز مربـع مجهـزة

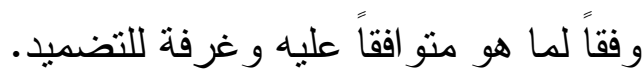
وجود ممرض أو ممرضة (إذا كانت عيادة نسائية يجب أن تكون ممرضة). تجهيز ها بالاثاث و التجهيز ات اللازمة. توفر الادوية و الوسائل الاسعافية الضرورية اللازمة. شروط ترخيص المجمع الطبي العام أو المتخصص:

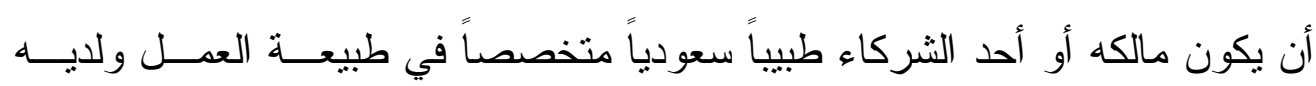
تزخيص مهني ساري المفعول.

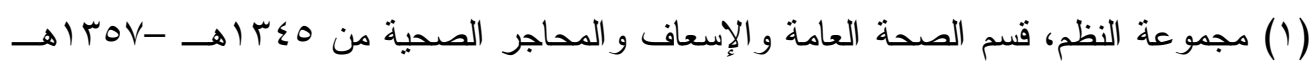

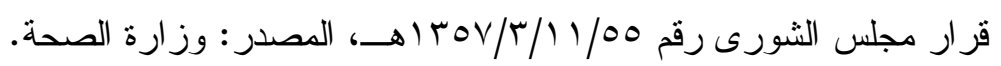




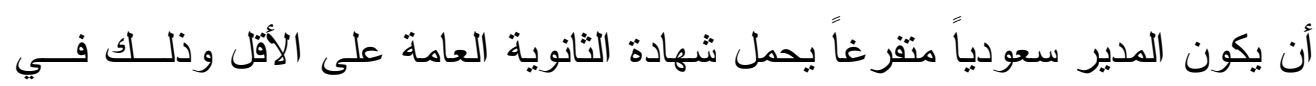
المجمعات التي تشمل أكثر من ثلاث عيادات.

أن يتضمن بالاضافة إلى المر افق العامة المذكورة أعلاه (الواردة بالمادة ب / 1 مسن

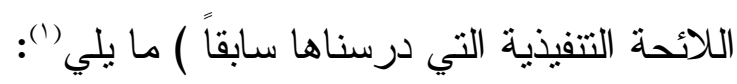

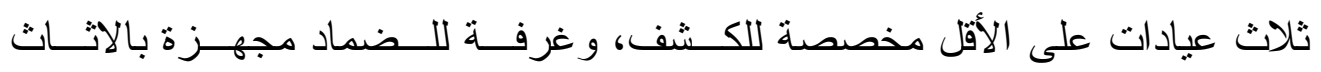

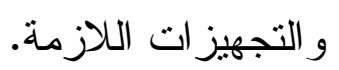

سيارة اسعاف حديثة الطر از ومجهزة حسب مـــا تقـرره الــوز ارة وذلــك بالنـسبة للمجمعات العامة.

تأمين سكن ملائم للطبيبات و الممرضات. توفير الأدوية و الاسعافات اللازمة.

تو افر اسنشاري على الأقل في كل التخصصات الرئيسية المرخـــة، وممــرض أو

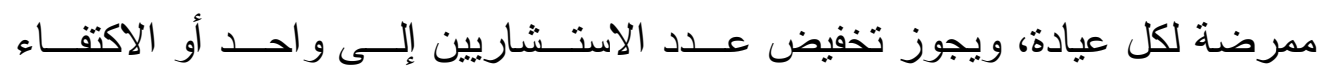
بالاخصائيين بالنسبة للمجمعات الطبية الموجودة في المناطق النائيــة التــي تحــددها

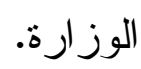

المؤسسات الصحية الثالثة. المختبر ات الطبية.

هناك مختبر ات عامة ومختبر ات متخصصة، كما يمكن أن يكون المختبر مسستقلاً أو ضمن مؤسسة صحية خاصة. العاملون بالمختبر : بالنسبة للمدير يجب أن يدار من قبل اخصائي في التحاليل الطبية

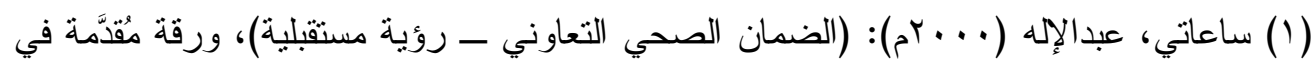

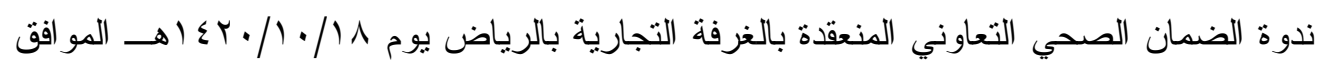
$\cdot$. 
مؤهل ومرخص له، أما العاملين يجب أن يكونو ا مــن الاخــصائيين ومــن الفنيـين

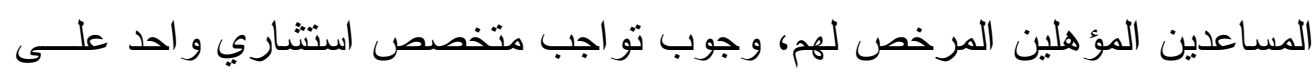
الاقل بالاضافة الى وجود اخصائي أول في كل تخصص متعارف عليه (تحاليل الدم

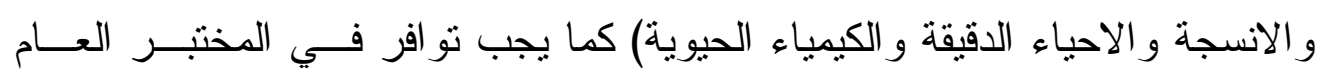
بالاضافة إلى ذلك شخص فني في كل تخصص. واء ولاء تجهيز ات المختبر ومر افقه و الفحوص المخبرية: يجب تجهيز المختبــر بــالتجهيزات

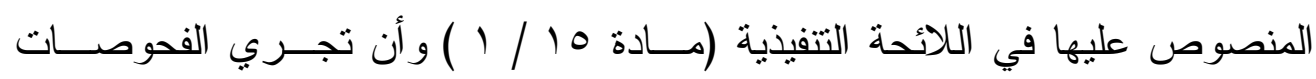
المخبرية وفق ما هو وارد باللائحة أيضاً. المؤسسة الصحية الر ابعة: مركز الاشعة:هنالك مركز للعلاج بالاشعة يرخص له فقط للمستشفى التي يتوفر فيها فنيون متخصصون في هذا النوع من العلاج. 


\section{المطلب الثاني \\ ضـوابط وشـروط انشـاء هذه المراكز:}

\section{بالنسبة لدكادر البشثري:}

القائم بالعمليات: يشترط في من يقوم باجر اء العملية تحت التخــدير العمــومي فـي

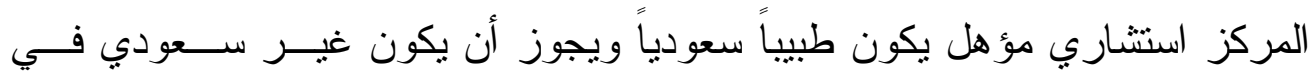
المناطق النائية. العمال: نو افر فنيين وممرضين متخصصين. أن يكون الفريق الطبي حاصلاً على دورات معتمدة في الانعاش القلبي الرئوي. بالنسبة للطبيب غير السعودي يجب أن يكون استشارياً ولايه نرخيص مهني سـاري

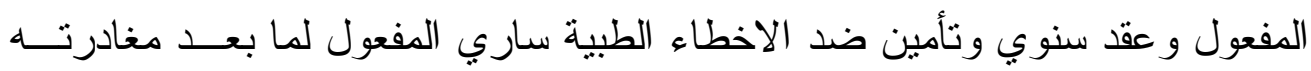
لمدة ستة أثنهر، على أن يتحمل المركز متابعة أي مضاعفات قد تتتج عــن الخطــأ الطبي.

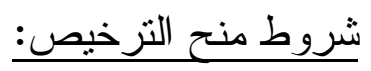

حصول الطبيب على مو افقة وزير الصحة بالعمليات المسموح بهاو ولا يجــوز لغيــر الطبيب المرخص له بالعمليات اجر اء العمليات، على أن يكون مالك المركز و الطبيب

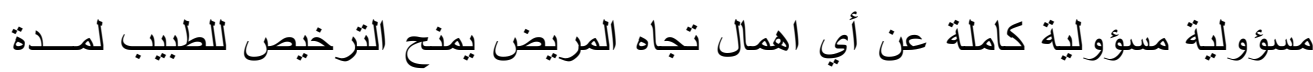

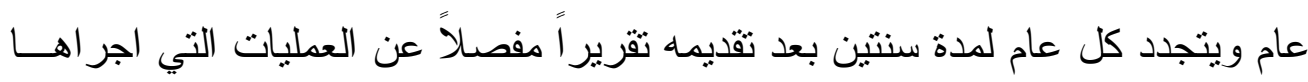
و أي مخالفات أو مضاعفات أو قضايا على الطبيب بعد ذلك يجدد الترخيص نظاميــاً

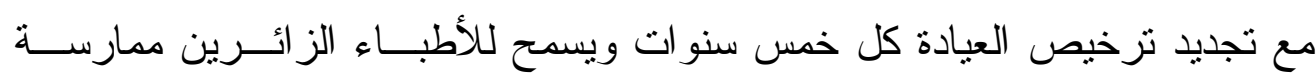
العمليات بعد حصولهم على ترخيص. أن يتو افر في المركز جميع التجهيز ات اللازمة للانعاش القلبــي الرئـوي علـى أن يشمل جهاز تتفس اصطناعي متتقل. 


\section{وجود طبيب تخدير مرخص له بمز اولة المهنة.}

وجود اتفاقية سارية المفعول مع احدى المستشفيات بقبول الحالات الطارئة التي تحال

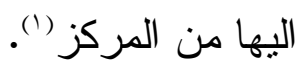

اقر ار من ماللك المركز بعدم قبول أن يبييث المريض بالمركز مهما كانت الظروف. ضرورة تحديد اجر العملية واعلام المريض بها قبل اجر ائها.

اما بالنسبة للشروط الو اجب تو افرها بالمبنى و التجهيز ات، فيجب التقيد بهذه الـشروط

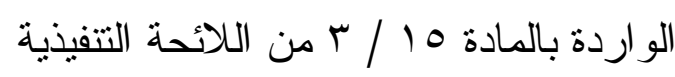
المؤسسة الصحية السادسة: مر اكز الخدمات الصحية المساندة)(r)

أنو اعه: نذكر على سبيل المثال مركز العلاج الطبيعي - مركز النظار ات الطبيـــة -

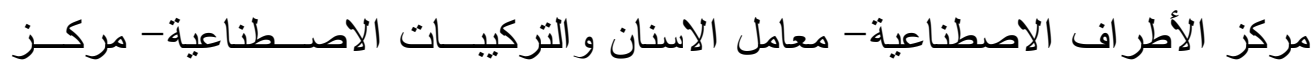
العلاج النفسي، و غير ها من المر اكز . كما يلزم الترخيص لتخصصات صحية اضافية أو اضافتها إلى مؤسـسـات موجــودة في الحالات التالية: مر اكز فحص العمالة الو افدة. مر اكز طفل الانبوب و العقم. مر اكز المعالجة بالليزر أو بالابر الصينية.

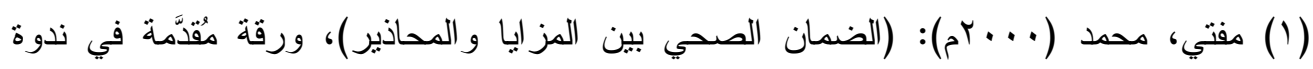

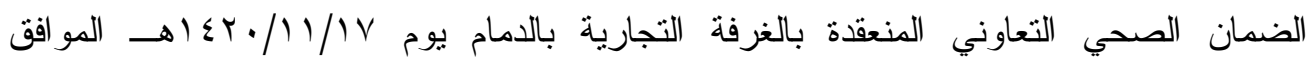
$\cdot$. (r) - نطور الخدمات الطبية بالمملكة العربية السعودية ودور الأجهزة المساعدة رقم

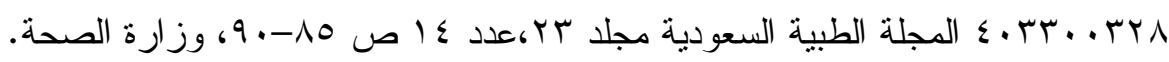


مر اكز المناظير الباطنية و الجهاز الهضمي.

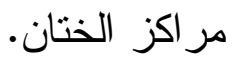

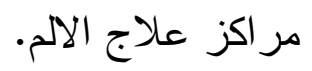
مر اكز جر احة المناظير . مر اكز الاشعة فوق الصوتية.

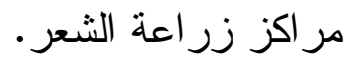
مر اكز زر اعة الاسنان.

أي تخصصات اضافية أخرى توصي باضافتها الهيئة السعودية للتخصصات الصحية ويو افق عليها وزير الصحة'('). المؤسسة الصحية السابعة مركز خذمات النقل الاسعافي

يشترط الترخيص له الالتز ام بالثروط و المو اصفات التي تحــددها الهــلد الاحمـــر السعودي ويشترط على صاحب المشروع تقديم خطة لتشغيل تشمل اسـلوب الادارة وتتظيم النقل و الاتصالات تو افق عليها الجمعية. العلاجات الاسعافية

القاعدة العامة: على المؤسسات الصحية الخاصة التاليــة المستـشفيات و المجمعـات الطبية و العيادات الخاصة التزام تقــديم الخــدمات الــصحية الاســعافية للحــالات الطارئة،ودون مطالبة مالية مسبقة.

العلاج الاسعافي يرتبط بحالة ناتجة عن مرض أو اصــابة يمكــن أن يهــدد حيــاة

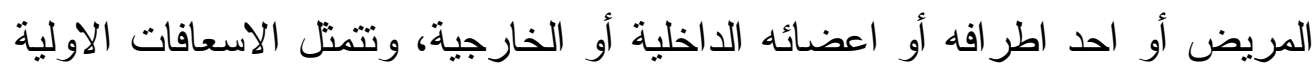

(1) - وزارة الصحة بالمملكة العربية السعودية (... بم)، دليل نظام الضمان الصحي التعاوني 
بالاجر اءات الطبية العاجلة التي تؤدي إلى استقر ار حالة المريض بشكل بسمح بنقله،

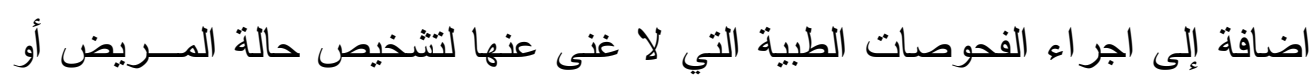
تقرير طريقة العلاج.

$$
\text { قو اعد علاج الحالات الاسعافية }
$$

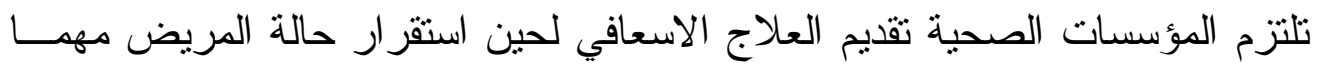
كانت جنسية المريض أو الجهة التي يعمل لديها.

و إذا تبين للمؤسسة أن المريض بحاجة إلى التتويم فعليها القيام بالاجر اءات التالية:

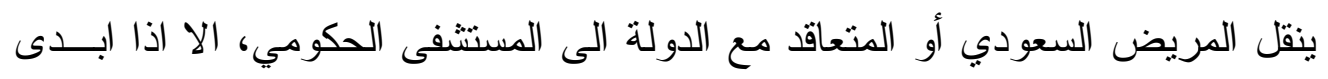

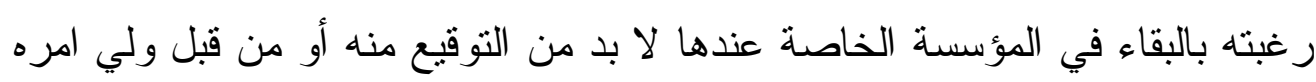
على تعهد بتسديد كافة التكاليف المالية. في حال عدم تو افر سرير بالمستشفى الحكومي بعالج بالمؤسسة الخاصة على حساب الدولة.

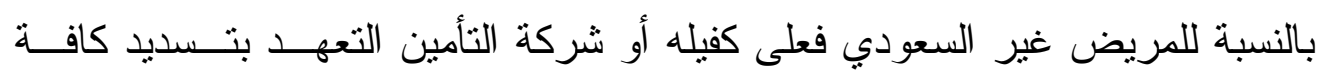
التكاليف إذا كان السعودي أو المتعاقد مع الدولة مشمول بالضمان الصحي فان شركة التــأمين

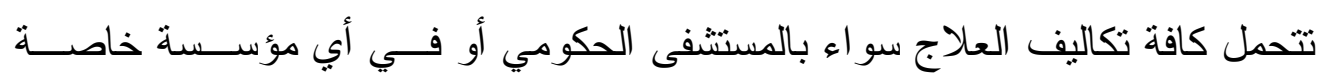

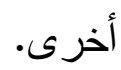

المر اقبة و التفتيش على المؤسسات الصحية الخاصة

لجان التفتش: تخضع كافة المؤسسات الصحية الخاصة للتفنيش من قبل لجان تفتيش تابعة لمديرية الثؤون الصحية في وزارة الصحة، وذلك من أجل التأكد من تطبيــق من فئن

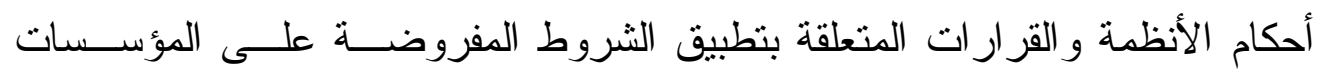
الصحية الخاصة ومر اقبة مستوى الجودة و النوعية للخدمات المقدمة. 
و اذا وجدت اللجنة مخالفات في المؤسسة الخاصة تحرر محضر اً بالمخالفات وتـشير فيه الى ملاحظاتها وترفق به الوثائق وتحيله الى مديرية الثؤون الــصحية لاتخــاذ

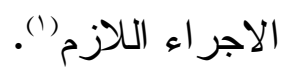

(1) - معالم النهضة الصحية، وزارة الصحة بالمملكة العربية السعودية، ه.ء اهـ، تهامة للإعلان . 


\section{المبلب الثالث \\ انتهاء الترخيص للمؤسسبة الصسحية المخاصسة \\ ينتهي الترخيه في الحالات التالية: \\ انتهاء مدته دون طلب صاحب المؤسسة التجديد.}

مرور 7 انثهر من تاريخ وفاة صاحب المؤسـسة دون أن بطلـبـ الورثــة تحويــل الرخصة لمصلحتهم.

يعتبر التزخيص ملغياً اذا قام صاحب المؤسسة بنقل ملكيتها الــى الغيــر، او تغيــــر نشاطها او مكانها دون مو افقة الوز ارة.

عاقبت المادة العشرين من نظام المؤسسات الخاصة تشغيل مؤسسة صـــية خاصـــة دون نزخيص الاغلاق وغر امة مالية تختلف قيمته بحسب نوع المؤسـسـة المخالفــة، هذا ما لم ينص نظام آخر على عقوبة اثند.

كما عاقبت المادة اب من النظام ذاته كل مؤسسة تخالف ابي حكم من احكــام نظـــام

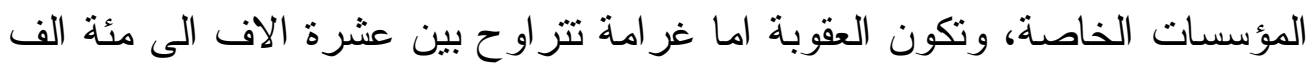

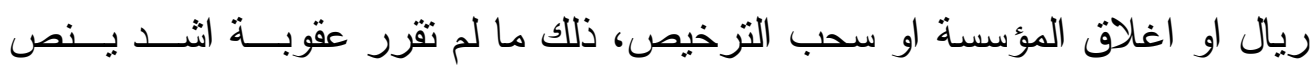

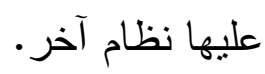
الجهة الصالحة لتوقيع العقوبات. اللجنة الطبية الثرعية ولجان مديرية الثؤون الصحية.

تختص هذه اللجنة بالنظر في الدعاوى و النزاعات الناجمة عــن الاخطــــاء الطبيـــة

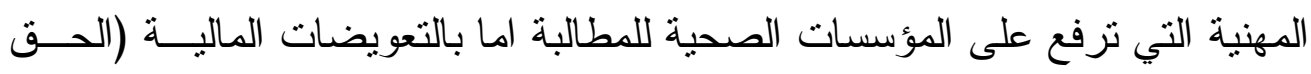
الخاص) وكذلك لا تز ال العقوبات الجز ائية اللازمة (الحــق العــام ) فيحيـلـل مــدير الثؤون الصحية المختص كافة الاور اق الطبية المتعلقة بالنز اع الى اللجنـــة الطبيـــة للنظر بمسؤولية المؤسسة الصحية. 
بالاضافة إلى ذلك هناك لجان تنظر بمخالفات احكام نظام المؤسسات الخاصة، يشكل

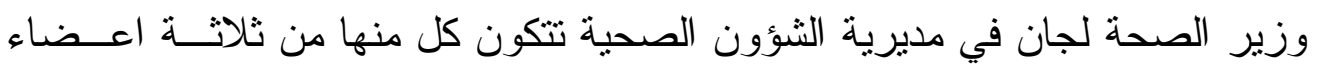

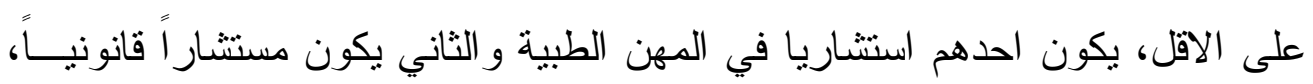
وتكون مدة العضوية فيها ثناثة سنو ات قابلة للتجديد. مهام او اختصاص اللجان: - مان تختص اللجان المذكورة بالنظر في المخالفات الناشئة عن نظام المؤسسات الــصحية الخاصة و لائحته التنفيذية ونوقع العقوبة المناسبة في حدود اختصاصها' (1).

(1) - الخدمات الصحية بالمملكة العربية السعودية، منصور النزهة، المجلة الجوية، ص هب-

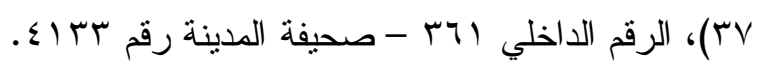




\section{المطلب الرابع}

\section{اجـراعات التتقاضسي امـام اللـجـان:}

تعقد اللجان جلساتها في مديرية الثؤون الصحية المختصة، ويتطلب صحة اجتماعها لحضور رئيس اللجنة أو نائبه و الممثل القانوني و الممثل الطبي وتـــدر قرار اتهـــا بالاغلبية المطلقة.

على اللجنة أن تقوم بالتحقيق اللازم و اخطار ذوي العلاقة وسماع اقــــال المخــالف و ادلاء اوجه دفاعه على ان تدون اعمالها في محضر رسمي، ويتم ابلاغ اصــحاب

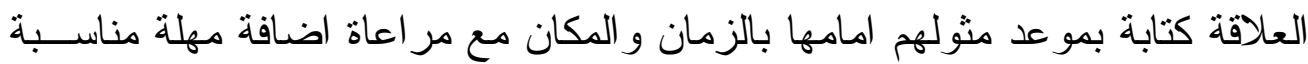
اذا كان الحضور بتطلب الانتقال من مدينة اخرى، ويجب الا يقل موعـد الحـضور عن • ب يوماً من تاريخ التبليغ اذا لم يحضر صاحب الثأن او وكيله الثرعي فاذا لم يحضر بعد ابلاغه الثاني فعلى اللجنة استكمال النظر في المخالفة و الفــصل فيهـــا اذا كانت جاهزة للحكم. بعد اصدار اللجنة قرارها عليها ان ترفعه الى وزير الصحة او من يفوضها وذللك من اجل اعتمادها وييلغ ذوو الثأن بقرار اللجنة المعتمد من الوزير في موعد لا يتجاوز

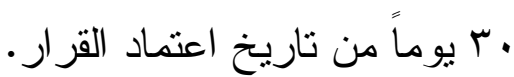
يجوز لذوي الثأن التظلم من هذه القرار ات امام ديو ان المظالم خلال ستين يوماً مــن تاريخ ابلاغ قرار اللجنة.

ينشر الحكم النهائي على نفقة المخالف في ثلاث صحف محلية تصدر احدها في مقر

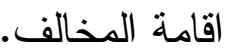

التز امات عامة تقع على المؤسسات الصحية الخاصة بالنسبة للعمال لايها:

على كل مؤسسة صحية خاصة ان توضـح للمتعاقدين لديها من العمال احكام انظمــة

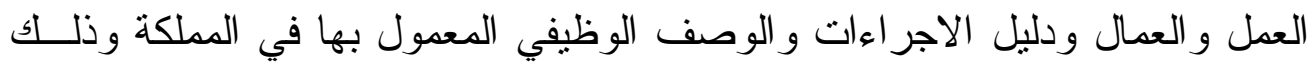


r ب بالنسبة للممارسين الصحيين.

على المؤسسة تمكين الممارسين الصحيين من حضور بر امج التعليم الطبـي

المستمر في مجال تخصصهم سو اء داخل المملكة أو خارجها وفقاً لما تحدده الهيئـة السعودية للتخصصسات الصحية.

تلتزم المستشفيات بتأمين مكتبة طبية بداخلها، وتلتزم بالاشتز الك في الدوريات العلمية في مجال تخصصها لتتيح للممارسين لديها الاطلاع علـى آخـر المـستجدات فــي تخصصهم و المساهمة في الابحاث العلمية، أما بالنسبة للمؤسسات الاخــرى فعليهــا توفير الدوريات العلمية الاساسية ذات العلاقة أيضاً. (1) ع. تلتزم المؤسسات الخاصة بتجنيد امكانيتها عند الضرورة وفي الحالات الطارئـة وذلك عندما يطلب وزير الصحة منها ذلك مقابل تسديد الحكومة كافة التكاليف. التبليغ عن أي حادث جنائي: على المؤسسة الصحية ابلاغ اقرب سلطة امن مختصة ومديرية الثؤون الصحية عن اي حادث جنائي او وفاة تحــدث للمرضــى لــديها، وتحتفظ بسجل كامل عن الحو ادث المرورية و الاصسابات التي عولجت لديها. 7. بالنسبة للاعاية:يحظر على المؤسسات الصحية ان ثقوم بالدعاية عن نفسها الا في الحدود التي لا تتعارض مع اخلاق المهنة ووفقاً للمعــايير التــي تحــددها الانئحـــة التتفيذية، بالاضافة الى وجوب حصولها على مو افقة مدير الثؤون الصحية(؟)

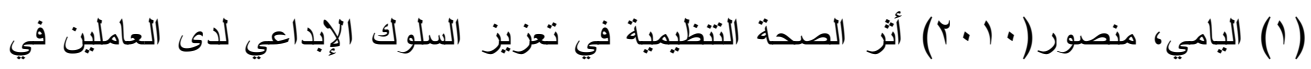
الغرف التجارية الصناعية في المملكة العربية السعودية، رسالة ماجستير غير منشوره، جامعة مؤتة. (Y) بحوث المؤتمر العالمي عن تاريخ الملك عبدالعزيز، جامعة الإمام محمد بن سعود الإسلامية، 7 • ع أهـ، الرياض. 


\section{النفمل الثناني}

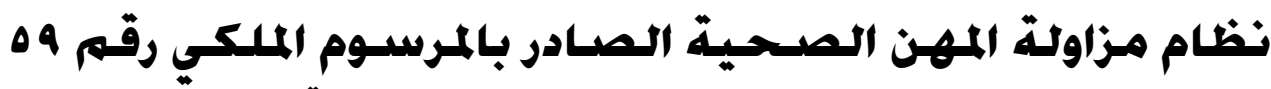

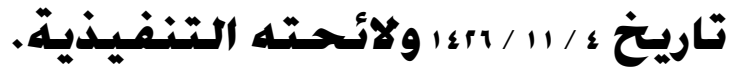

\section{المبسحث الاول}

الترخيصل بمزاولة المهنة المسحية للسمهارسيين المسحيين

\section{المطلب الاول}

\section{شـروط التترخيص بمسزاولة المهـن المسحية (1)":}

أوجبت المادة الثانية من نظام مزاولة المهن الصحية عدة شروط للترخيص بمز اولة المهن الصحية وهي

الحصول على المؤهل العلمي المطلوب للمهنة من الكلية المناسبة (كلية طــبـ، كليــة صيدلة، كلية علوم تطبيقية، معهد صحي) أو أي مؤهل آخر مطلوب لمز اولة مهنـــة

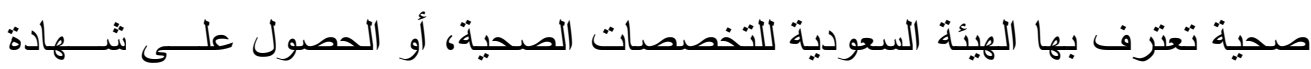
من الخارج تعتزف بها الهيئة المذكورة. وتقوم الهيئة بالتصنيف المهني للممارسـين على ضو ء الثهادات و المؤهلات وتكون مسؤولة عن تسجيلهم و الاحتفــاظ بقاعــــة

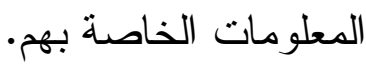

أن يكون الممارس الصحي ق د أمضى مدة تدرييه الالز امية، وان تتو افر لديه اللياقة

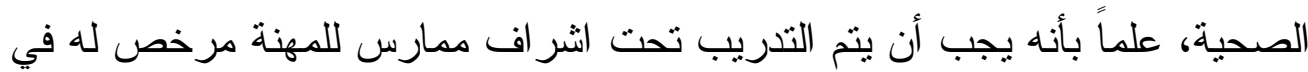

(1) أثنارت المادة ؟ / r من اللائحة التتفيذية لنظام مزاولة المهن الصحية ان الممارس الصحي

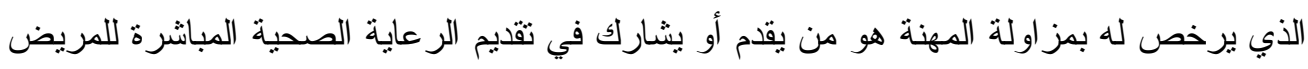

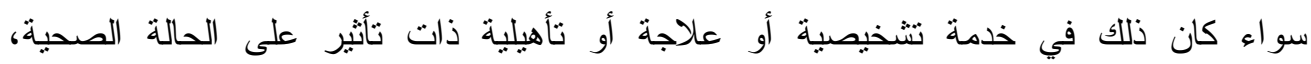

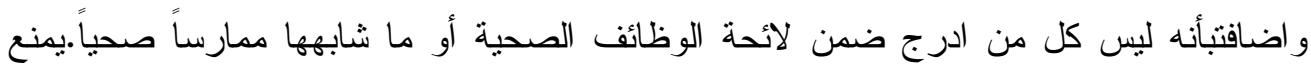

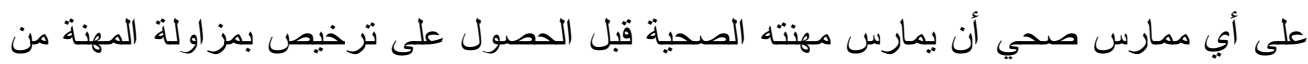

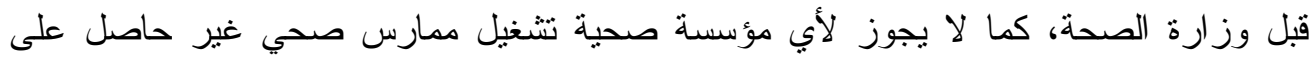
الترخيص. 
ذات المجال وتبلغ الهيئة الجهات الصحية المختصة عن الذين تثبت عدم صلاحيتهم لممارسة المهنة.

أن يسجل الممارس الصحي نفسه في الهيئة السعودية للتخصــصـات الــصحية وفقــاً للمتطلبات التي تحددها الهيئة.

ألا يكون قد سبق وحكم عليه بجريمة مخلة بالثرف والامانة (كجريمة التزوير ، و الغش وسحب شيك بلا رصيد والسرقة و الاحتيال... الخ) الا إذا رُد اليه اعتباره.

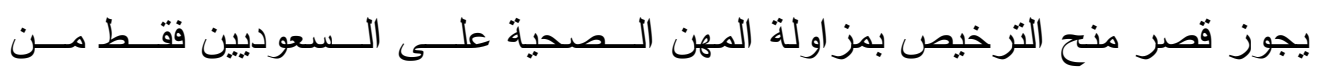
الممارسين الصحيين دون غيرهم، اما لمقتضيات المصلحة العامة، و واما لتو افر العدد الكافي منهم في المملكة أو في احدى المناطق. الجهة المختصة لمنح الرخص (1) يعطى الترخيص النهائي من قبل ادار ات الرخص الطبية والصيدلية بمديرية الثؤون الصحية التابعة لوز ارة الصحة.

على أنه يجوز منح نرخيص مؤقت للفئات التالية بعد الموافقة على مؤهلاتهم، الاطباء الزائرين أو من في حكمهم، وكذلك الممارسين الذين يتم التعاقد معهم خلال فترة اجر اءات التصنيف و التسجيل المهني. تتولى الهيئة ابلاغ الجهات الصحية و غيرها عن تزوير الثهادات أو أي تلاعب بها،

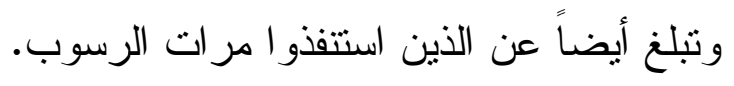
وبالنسبة لممارسة العلاج الثعبي:

لا يجوز ممارسة هذه المهنة الا بعد ترخيص من الجهة المختصة التي تحددها الوز ارة بناء على شروط وضو ابط معتمدة، و عندها يخضع الممارسة للمسؤوليات

(1) باز ، علاء(· (ب)، دالة الإنتاج في القطاع الصحي السعودي، رسالة ماجستير غير منشورة

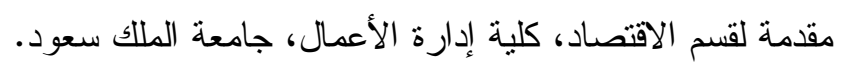


التي يخضع لها الممارس الصحي المدرجة في نظام مز اولة المهن الصحية. يجب الانتباه إلى وجوب مر اعاة القو اعد و الاحكام ذات العلاقـــة بممارســـة المهنـــة

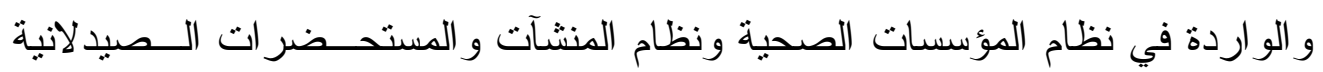
عند الترخيص للممارسين بالعمل لدى أي من هذه المؤسسات أو المنشآت. (1)

\section{المطلب الثاني

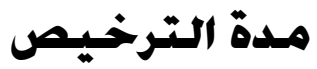

بالنسبة للممارسين العاملين في الجهات الحكومية(r):

يعتبر التزخيص سارياً طالما الممارس على رأس العمل الطبي، على أن ير اعى تجديد التسجيل لدى الهيئة السعودية للتخصصات الصحية عند انتهائه. بالنسبة للممارسين الصحيين في المؤسسات الخاصة: تكون مدة الترخيص معادلة لمدة التسجيل لدى الهيئة وفي حال تغيير مكـــان العمل خلال مدة التسجيل المهني دون تغيير التخــص، يظــل التــسجيل ســاري المفعول.

لا يجوز لمن انقطع عن مزاولة المهنة مدة سنتين متتاليتين لغير اغراض الدراسة

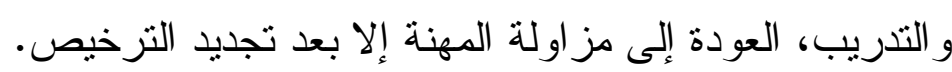

يجدد التزخيص وفقاً للشروط الواردة في نظام مز اولة المهن الــصحية (أي شــروط الترخيص بمز اولة المهنة الصحية المذكورة سابقاً).

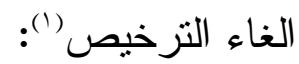

(1) - ملاّ، عادل محمد (1 . بام): خصخصة المستثفيات العامة وتطبيقاتها في المملكة العربية السعودية. جدة، مطبعة الخطوط السعودية.

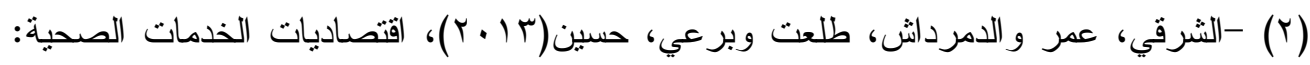

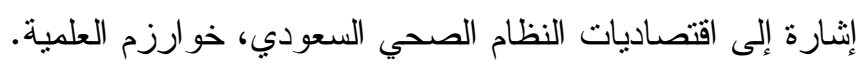


عدم تجديد الترخيص قبل انتهائه، ويعتبر التزخيص لاغياً من تاريخ انتهاء مدته دون تجديد.

عند انتهاء التزخيص للمؤسسة الصحية التي يعمل بها الممــارس الــصحي أو عنــــ

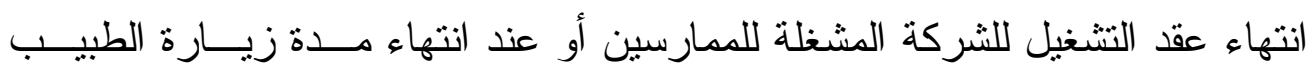
المرخص بالعمل له خلالها. عند تغيير الممارس مكان عمله أو نوعه أو تخصصه دون موافقة وزارة الصحة، باسنتناء الممارسين العاملين لدى الجهات الحكومية. إذا صدر قرار من الجهة المختصة بايقاف الترخيص أو الغائه. وفاة صاحب الترخيص.

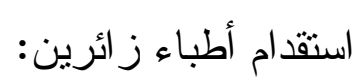
القو اعد التي تحكم استقدام الأطباء الز ائرين:

هناك عدة شروط وقو اعد تحكم استقدام الأطباء الز ائرين إلى المملكة وهي التالية: أن يكون الطبيب الزائر في رتبة طبيب استشاري في بلده، أو من ذوي التخصصات

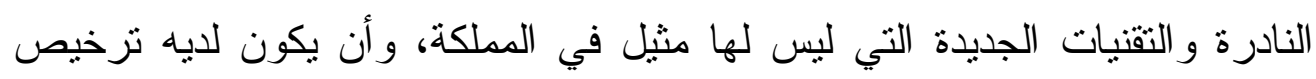
بمز اولة المهنة ساري المفعول في بلده.

يقتصر استقدام الاطباء الزائرين على المستـشفيات و المجمعــات الطبيــة المهيــأة لتخصص الطبيب الزائر . - م. غير محكوم على الطبيب المستقدم بحكم الحد الثرعي أو بحكم جنائي (ارتكاب جرم

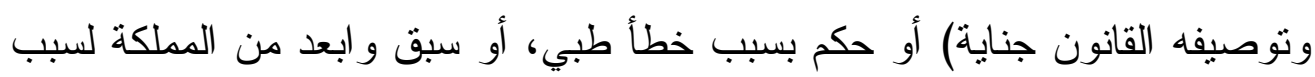
له علاقة بمهنة الطب.

(1) وفقاً للمادة ؟/ ب من اللائحة التتفيذية يعتبر الترخيص لاغياً في الحالات التالية:

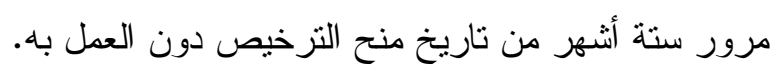


أن بر اعى في تحديد مدة الزيارة الوقت الكافي لتقييم الاجراءات الطبية التي تمت خلال الزيارة.

تعهد من المؤسسة الصحية بضمان سداد التعويضات التي قد يصدر بها حكم قضائي

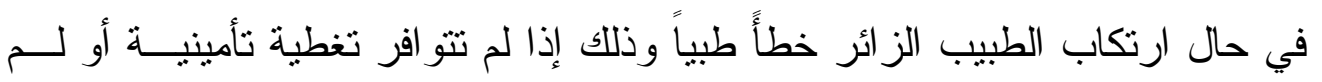
تكف التغطية.

يقدم طلب استقدام الطبيب الزائر إلى مديرية الثؤون الصحية التابعة لها المؤسسة الصحية، ويجب أن يرفق الطلب بالمستتدات التالية: صورة من الثهادات و السيرة الذاتية على أن ترسل صورة منهما إلى الهيئة لتقييمها. برنامج الزيارة.

اقر ار من الطبيب بالعمل وفق الانظمة السعودية واحتر ام المبادئ الاسلامية. اقر ار من الطبيب المر افق بالمو افقة على مر افقة الطبيب الزائــر ومتابعــة الحــالات المرضية التي عالجها الطبيب الز ائر ومو اجهة مضاعفاتها. بعد مو افقة الهيئة على طلب الاستقدام، تقوم مديرية الثؤون الصحية بمنح المو افقة النهائية على الاستقدام ويصدر الترخيص المؤقت بمز اولة المهنة للطبيب الزائر بعد وصوله وينتهي التزخيص بانتهاء الزيارة.

يجوز استقدام استشاريين من غير الاطباء ذوو التخصصـات النادرة ويطبـق علــهـم قو اعد استقدام الاطباء الزائرين (1).

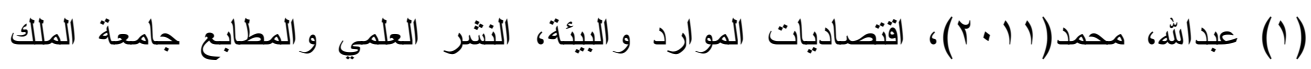

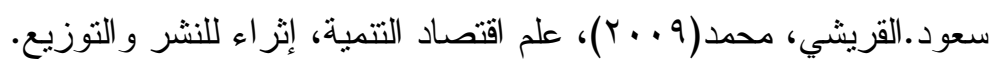




\section{المطلب الثانث}

\section{واجبات الملمارس المسحي '(1):}

هناك و اجبات متعددة القاها نظام مز اولة المهن الــصحية و لائحتـــه التتفيذيــة علــى

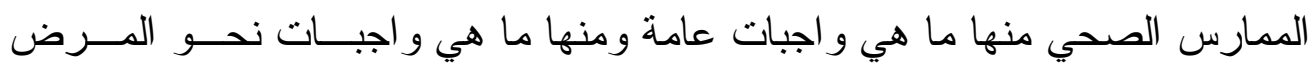
ومنها و اجبات تجاه زملائه من الممارسين، ففي كافة هذه الو اجبــات هنــالك اعمــال

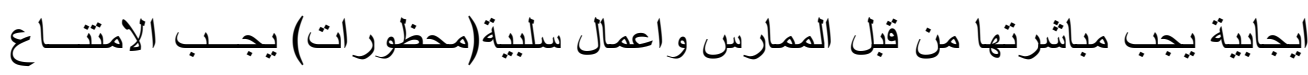
عن اثباتها.

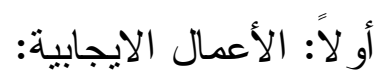
() يز اول الممارس الصحي مهنته في نطاق احتر ام حقوق الانسان وسلامته وكر امته لذلك وجب عليه ممارسة المهنة في المملكة وفق لما تقضيه العادات و التقاليد الــسائدة

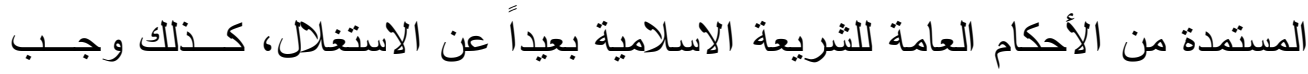
عليه احتر ام حقوق الانسان المستمدة من الاستور السعودي و الاتفاقيات الدوليــة ذات الصلة اهمها الاعلان العالمي لحقوق الانسان الصـادر عام 9 ـ 1 فعليه مثنا احتــرام حق المريض في الاختيار (مثناً اختيار الطبيب المعــالج) وفـق الحــدود الـشرعية و النظامية.

r) ان النظام الصحي السعودي القى على عاتق الدولة و اجب تقديم الرعاية الــصحية و المحافظة على الصحة العامة بشموليتها فعلى الممارس الصحي معاونـــة الــسلطات العامة في اداء واجباتها نحو الصحة العامة، حيث ان الدولة بلسطاتها المختلفة ملزمة حماية المو اطنين و المقيمين على ارضها ضد اي اخطار صحية قد تصيبهم سو اء في حالة السلم او في حالة الحرب، كحمايتهم ضد الامر اض المعدية و الاوبئة الخطيــرة

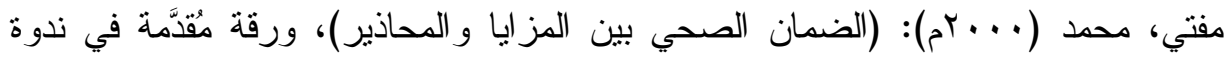

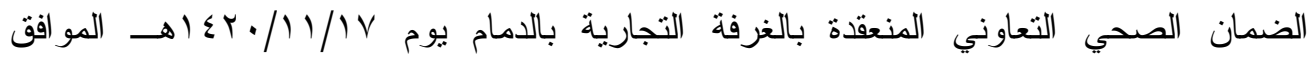

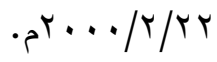


كالايدز و الجدري و غير ذلك وتتوجه اليهم بالتحــذيرات اللازمــة، ان المـساعدين

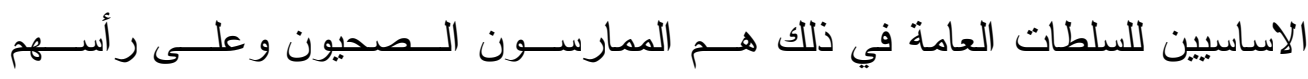
الاطباء.ب) على الممارسين الصحيين (الاطباء على وجه خاص) تتميــة معلومـــاتهم المتعلقة بمهنتهم وذللك من خلاء حضور الندوات و المحاضر ات العلمية ذات الــصلة، و اجر اء الابحاث في اختصاصهم او المشاركة فيها وحــضور المــؤتمر ات وتقــــيم اور اق عمل فيها قدر الامكان وذللك ليبقى الممارس الصحي على اعلى مستوى مــن

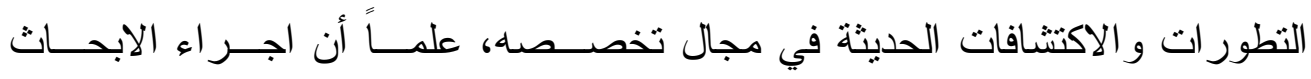
و المشاركة في المؤتمر ات تؤخذ بالاعنبار عند النظر في نزقية الممارس الــصحي او في اعادة تسجيله او تجديد التزخيص بمز اولة المهنة(1).

§) على الممارسين الصحيين (الاطباء على وجه خاص) تتمية معلومسـاتهم المتعلقــة

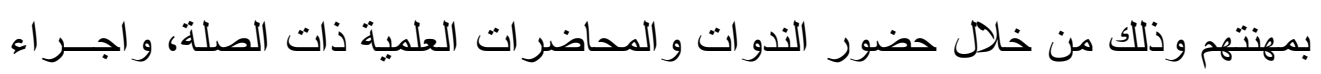
الابحاث في اختصاصهم او المشاركة فيها وحضور المؤتمرات وتقديم اوراق عمـلـل

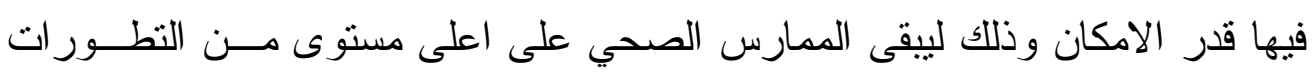

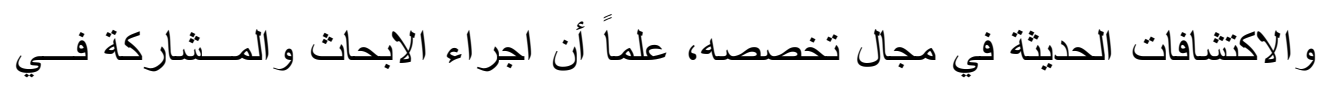
المؤتمرات تؤخذ بالاعنبار عند النظر في ترقية الممارس الــصحي او فـي اعـادة تسجيله او تجديد التزخيص بمز اولة المهنة. وتلعب الهيئة السعودية للتخصصات الصحية دوراً فعالاً في هــذا المجــال اذ تقـوم

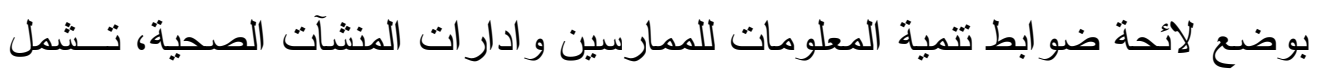

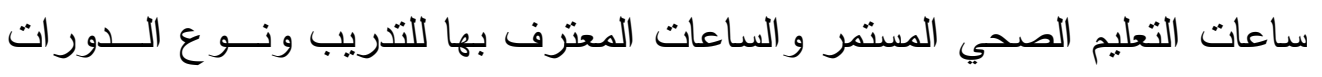
المطلوبة ونشر هذه الضوابط بالطريقة الاعلامية المناسبة، وفي هذا الـسياق علـى ولى ونى المنشآت الصحية تمكين الممارسين الصحيين من استكمال ساعات التعليم الصحي بما لهابـ

( (1)الهيتي، أحمد؛ علي، عدي؛ خلف، فاطمة(9 . ب)، "العلاقة بين الإنفاق على الصحة و التعليم

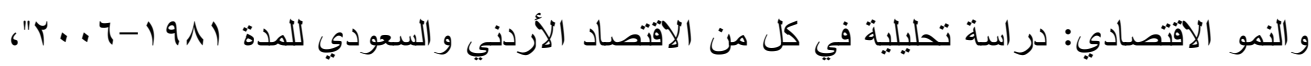

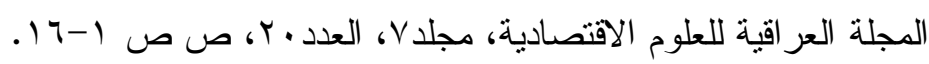


لا يتعارض مع التز ام الممارس الصحي تجاه المرضى. 0)يقع على الممارس الصحي واجب تقديم العناية الطبية والرعاية العاجلة في حـال علم او شهد حالة المريض اوجريح يحتاج إلى منل هذه الرعاية الفورية، ولا يجــوز

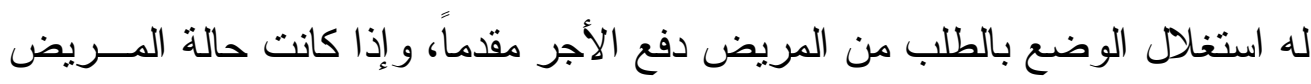

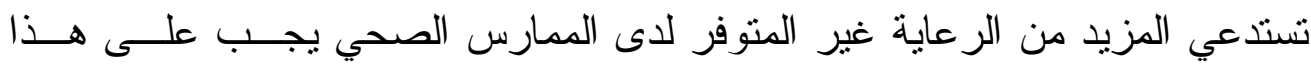
الأخير مساعدة المريض على تأمين نقله إلى أقرب مركز ملائم للمعالجة.

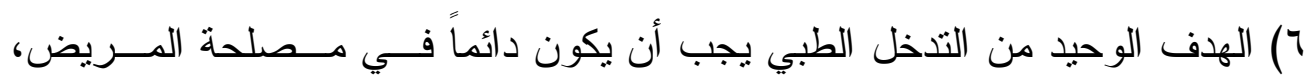

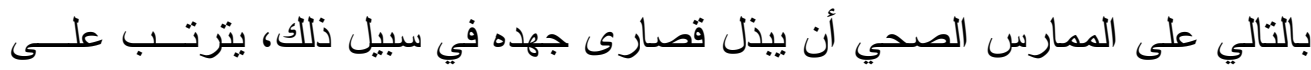

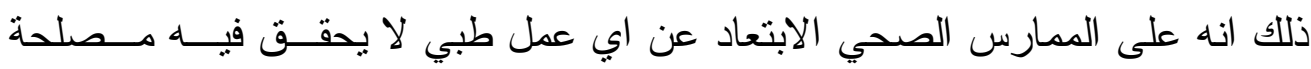
المريض حتى ولو لم يترتب ضرر عليه، على سبيل المثال وصف دواء لا لزوم له، تتويمه بالمستشفى من غير داعي للتنويم، اجر اء عملية غير ضرورية القيام بأعمـال تجارب طبية على المرضى.

V) يقع على الممارس الصحي أو على المؤسسة الصحية التي يعمل لــديها عنــدما

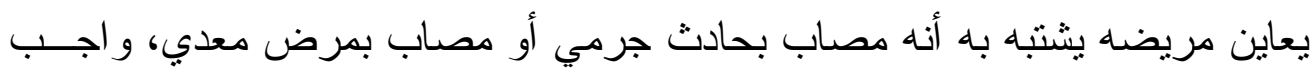

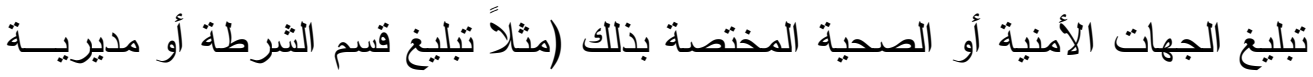
الثؤون الصحية أو أي جهة حكومية ذات اختصاص) يجوز للممارس أن يبلــنغ ادارة المؤسسة التي يعمل بها وبذلك يعتبر أنه نفذ واجب التبليخ. على أن تقوم وز ارة الصحة باصدار قرار تحدد بمقتضـاه الامــر اض المعديــة التـي

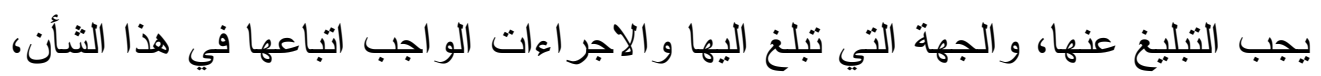

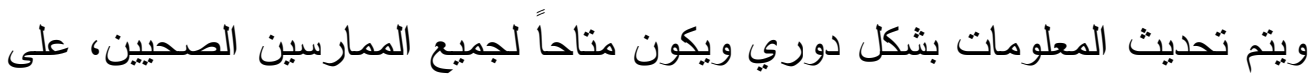
أن يلتزم الممارس الصحي بما يصدر من قرار ات وتعليمـات تـنظم التبليــنغ عــن الأمر اض المعدية') - (1)

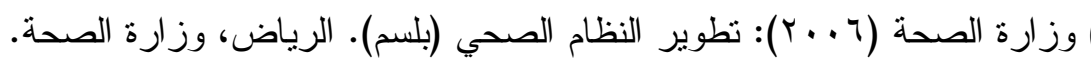




\section{المطلب الرابع \\ واجبات المهمارس المسحي بخّاه المرضى}

عندما يز اول الممارس الصحي مهنته الصحية انما يقـوم برســالة الــصحة العامــة لمصلحة الفرد و المجتمع، فعليه احتر ام حق المريض بالاختيار وفق الحدود الثرعية و النظامية وقد القى عليه نظام مزاولة المهن الصحية و لائحته التنفيذية العديــد مــن الو اجبات تجاه المرضى نذكر منها التالي:

() على الممارس الصحي أن يقوم بالنتشخيص بالوسائل الفنــــة الملائمــة بالعنايـــة

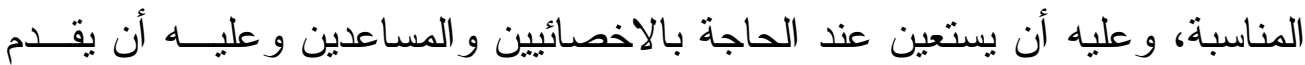
للمريض ما يطلبه من تقارير عن حالته الصحية ونتائج الفحوصــات، لكــن يجــبـ

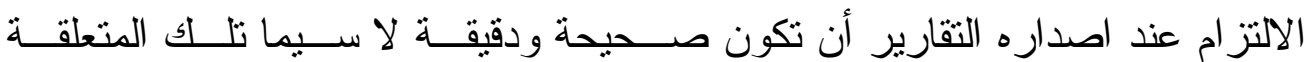
بالاجاز ات المرضية و اللياقة الصحية و التقارير الخاصة بالاصابات الجنائية وشهادات الوفاة وغير ها من التقارير الرسمية.

r) على الممارس الصحي اخبار المريض بالاماكن التي تتوافر بها الخدمة الصحية

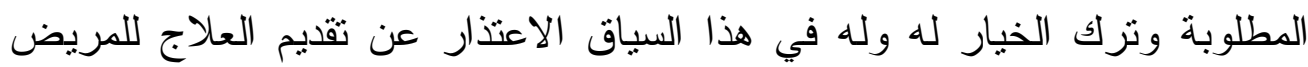
لاسباب مهنية او شخصية مقبولة وذلك في غير الحالات الخطرة او العاجلة.

r) على الممارس الصحي المعالج أن ينبــهـ المــريض أو ذويـــهـ إذا رأى ضـــرورة

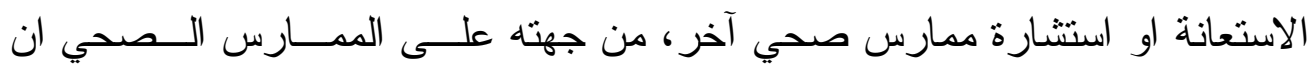
يتقبل مساعدة ممارس صحي آخر اذا طلب منه المريض أو ذووه ذلك. الا ان له الحق في ان يقترح اسم الممارس الصحي الاخر الذبي ير اه مناســباً وفــي

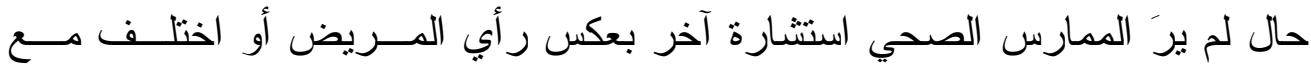
الممارس الصحي الاخر بالر أي الطبي، فله الحق عندها الاعتذار عن متابعة العــلاج

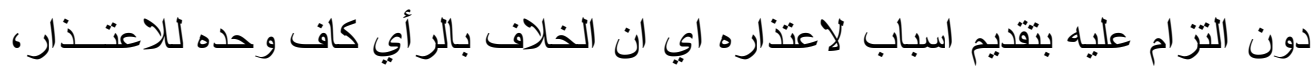

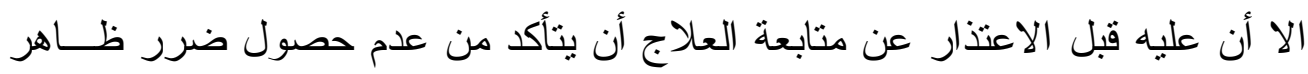




\section{للمريض (')}

ع) على الممارس الصحي أن ينبه المريض او ذويه غلى ضرورة اتباع التعليمات

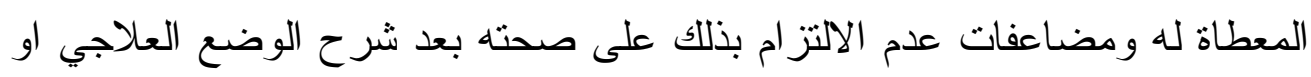

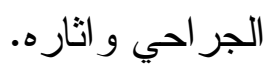

اما اذا كان المريض مصاب بمرض خبيث او مستعصي(كالسرطان مـنثلاً) ويهـدد

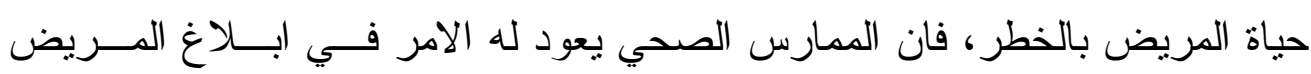

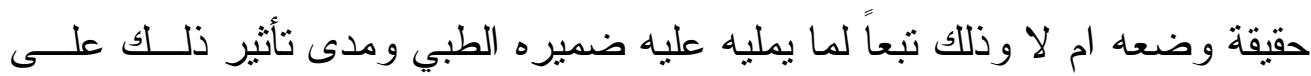

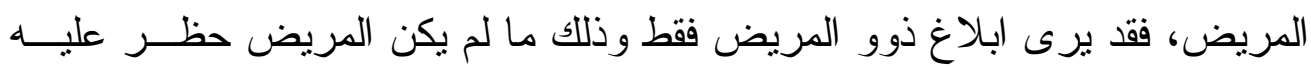

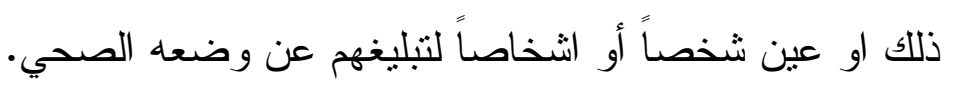

0) كل عمل طبي سواء كان تشخيص عادي أو عملية جر احية كبيــرة ام صــيرة

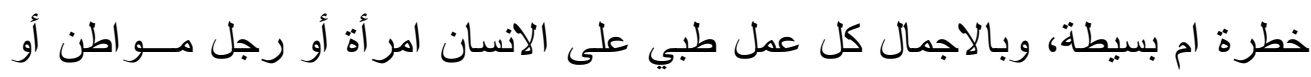

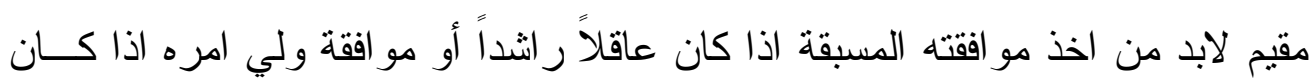

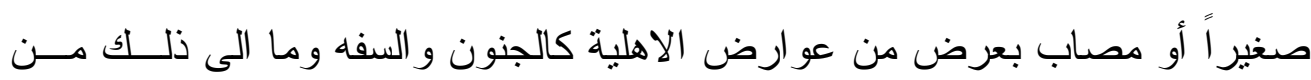
امور تجعل ار ادته غير معتد بها.

لكن في حالات الحوادث او الطوارئ او الحالات المرضية الحرجة التـي تـستدعي

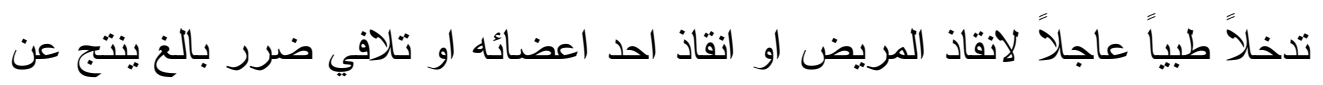
التأخير في التشخل الطبي الفوري وتعذر الحصول على موافقة المريض او ولي امره في الوقت المناسب فالممارس الصحي عندها اجراء العمل الطبي قبل الحصول على

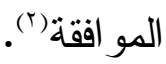

ا) في تقارير الوفاة: عندما يستدعي طبيب للتوقيع على كثف طبي لشخص منوفى

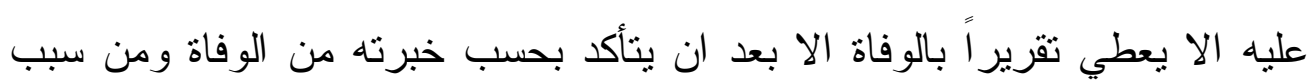

(1) - وزارة الصحة بالمملكة العربية السعودية (ب... (r)، دليل نظام الضمان الصحي التعاوني.

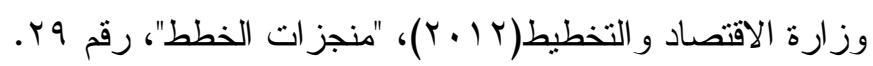


الوفاة وذلك بعد اجر اء الفحوصات السريرية الدقيقة وتأكده من توقف الوظائف الحيوية للجسم و اثبات وقت الوفاة.

و عند اثنتباه الطبيب ان الوفاة عائدة الى حادث جنائي او تسمم عليه ان يقوم بابلاغ الجهات الامنية المختصة فور اً، و اثبات الاصابات بتقرير طبي بسلمه للشرطه المعنية لطلب الطبيب الثر عي. اذا ارتأى الطبيب الثرعي ضرورة تشريح الجثنة لاثبات سبب الوفاة عليه ان يطلـبـ ذلك من الجهات الامنية لاستصدار امر التشريح.

V الحفاظ على السر المهني: يعتبر موضوع السر المهني الطبي من المو اضيع بالغة

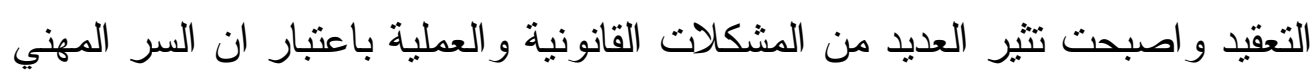
وموضو عه يعد من الضمانات الاساسية لحقوق الانسان وقد ورد ذلك فــي الاعــلان

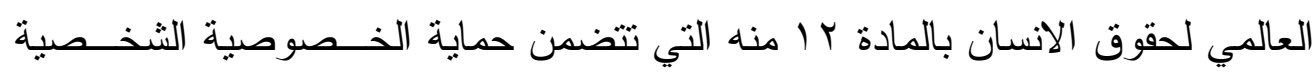
لأفر اد.

يأتي الالتز ام بالاحتفاظ بالسر الطبي ضمن قائمة الأسرار المهنية التي يتوجب على

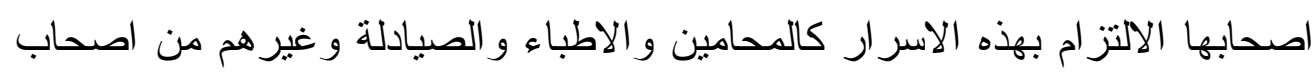

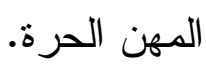
وقد يصل الامر الى اعتبار افشاء السر المهني بشكل عام والسر الطبي بشكل خاص جريمة جز ائية يعاقب عليها القانون.

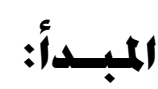

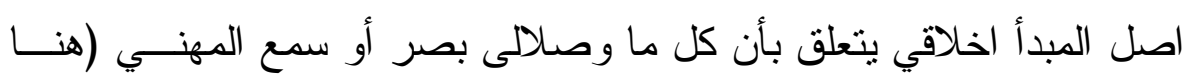
المقصود به الممارس الصحي) اثثاء قيامه بمهامه او بمعرضـــها يمسس المــريض ويتطلب كتمانه يجب كتمه و المحافظة على اسر ار الناس، ومن حقالمريض ان يتوقع الا يقوم طبيبه او الممارس الصحي يتقديم اي معلومات شخصية لجهة اخرى و التـي

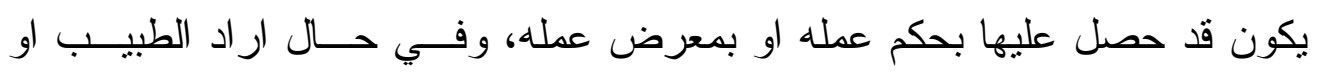


الممارس الصحي رفع هذه المعلومات الى جهة معينة دون موافقة المريض عليه ان

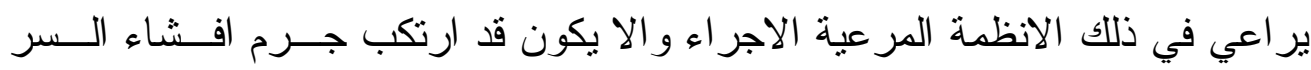
المهني.

ما هو السر الطبي او المتعلق بمهنة الممارس الصحي ('). هو الذي يعلمه الطبيب أو الممارس الصحي اثثاء التشخيص وتقديم العناية الــصحية

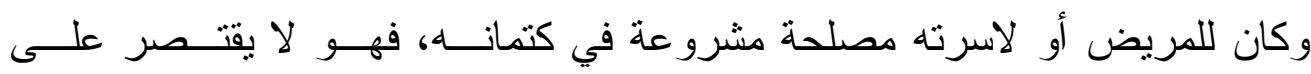

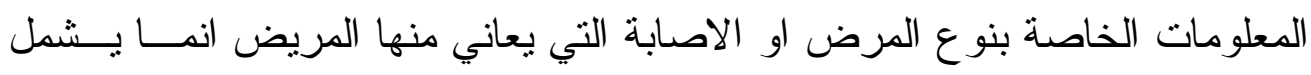
على كل ما يتصل بالعمل الطبي مـن فــص وتـشخيص، كــاجر اء التـشخيص

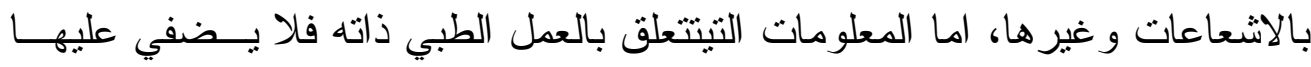

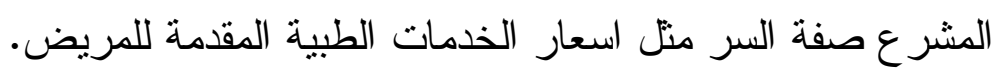
ويجري العرف على اعتبار بعض الامر اض من قبيل الامر اض التي لا يجوز افثاء سرها كمرض البرص و الجذام و الزهري و السيلان وهي الامر اض التي تعثبر معدية

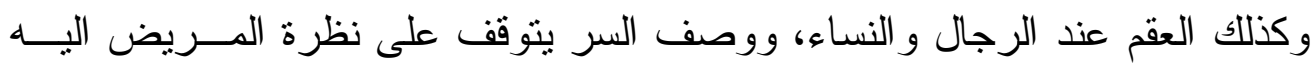
بغض النظر عما ير اه الطبيب، فالمريض هو صاحب السر وهو الذي يمكنه ان يقدر اثار افنتائه السلبية. من جانب آخر يجب ان يكون السر لله صلة بالمهنة الذي يمارســـا المهنـي، علــى

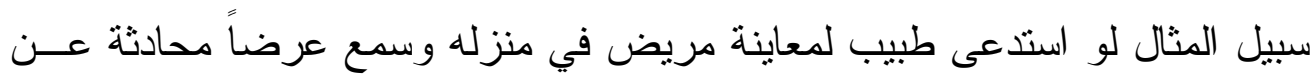
ارتكاب جريمة قتل، فهو غير ملزم بالكتمان اذ ليس لهذه الوقائع صلة بالمهنة التـي يمارسها و اتى الى المنزل على اساسها.

(1) تشارلز، فيلبس(r ( ب)، اقتصاديات الصحة و الرعاية الصحية والتأمين الصحي: المسار الأمريكي، المكتب العربي الحديث.

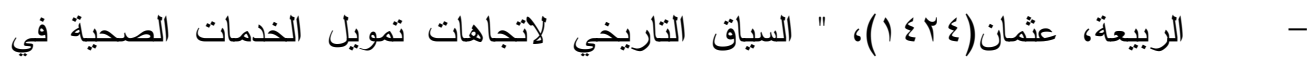
المملكة وتوجهات المستقبل"، السلسلة العمية لجمعية الاقتصاد السعودية، مجلده، العدد 9. 
على اية حال ان اعتبار الوقائع افثناء لسر مهني طبي امر يعود الى السلطة الثقديرية للقاضي الناظر في النزاع. على انه يجب العلم ان السر الطبي لا يقتصر على افثناء نوع المــرض او علاجــــ لكنه يشمل كافة الامور المتصلة بالعمل الطبي.

و المحافظة على السر المهني يقضي بألا يقوم الطبيب او الممارس الــصحي بافـشاء السر الطبي اي كثفه و اطلاع الناس باي وسيلة سو اء بطريق مباشر او غير مباثـــر

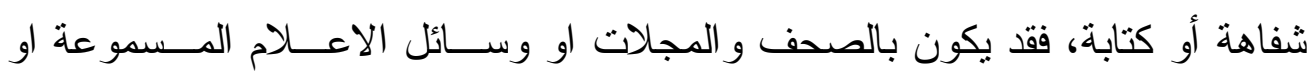

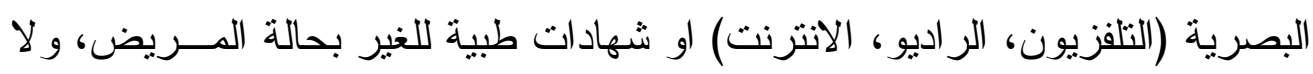

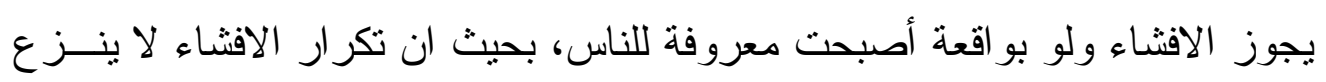
عنه صفة السرية بل يظل الافثناء معاقباً عليه مهما تكرر. الثهادات الطبية بعدم اللياقة. تص قو انين الخدمة المدنية على وجوب حصول المرشح للوظيفة على تقرير طبي من طبيب مختص يثبت لياقته الطبية لشغل الوظيفة. فالطبيب المختص لا يجوز له أن يشير في تقريره الطبي الى تفاصيل المـرض بــل

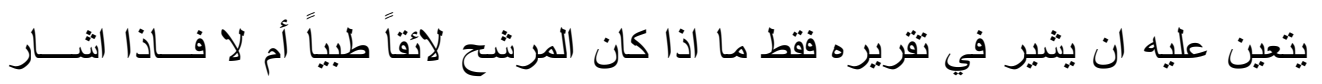

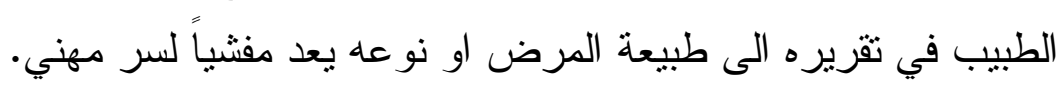
يقتضي افثناء السر المهني في القطاع الصحي ان يكـون صــادراً عــن الممــارس

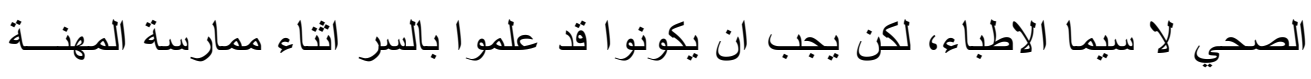

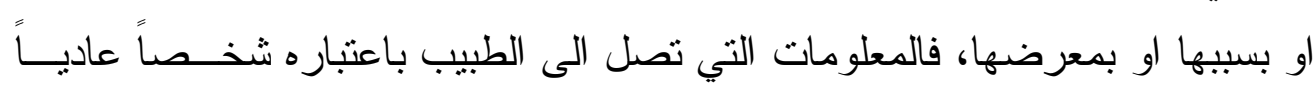

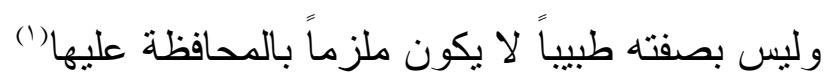

(1) الربيعة، عثمان(ع ؟ ())، " السياق التاريخي لاتجاهات تمويل الخدمات الصحية في المملكة ونوجهات المستقبل"، السلسلة العلمية لجمعية الاقتصاد السعودية، مجلده، العدد 9. 


\section{المبسث الثناني}

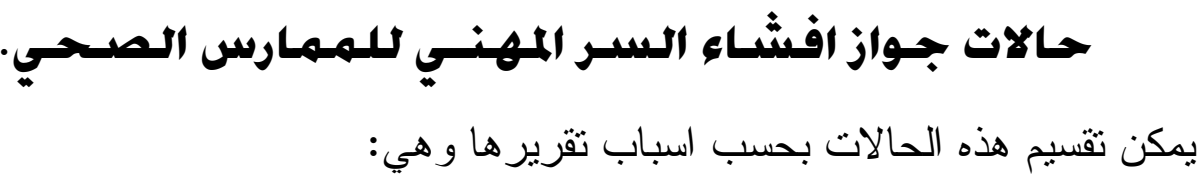

\section{المطبب الاول}

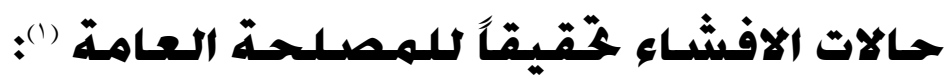

او لا: الابلاغ عن حالة وفاة بحادث جنائي: اذا قدم الممارس الصحي العناية الصحية

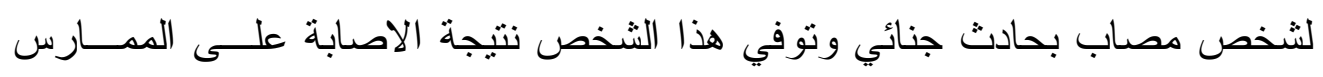

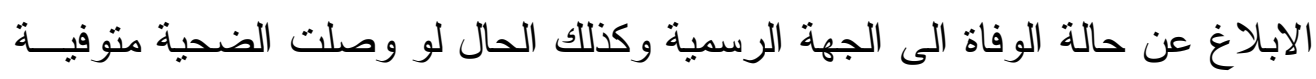

$$
\text { بحادث جنائي. }
$$

ويمتد هذا الحكم ايضا على حالة المتوفيين بشكل طبيعي اذا نوفو ا بالمؤسسة الصحية

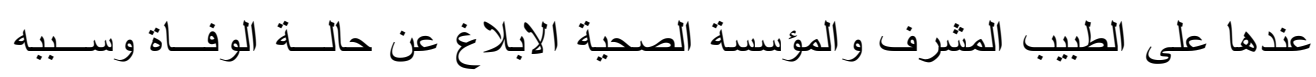
وتاريخه ويمتد هذا الحكم على معالجة شخص اصابته ناجمة عن حادث جنائي. الافثناء عن سر للحيلولة دون ارتكاب جريمة: فالطبيب مثناً الذي يشاهد احد مرضاه

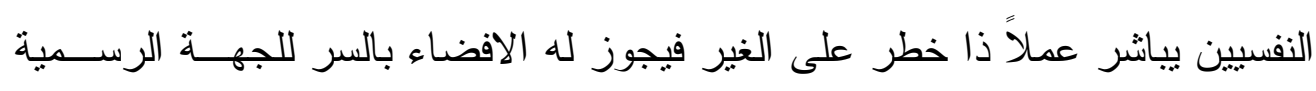
المختصة لتفادي وقوع العمل الجرمي

الابلاغ عن مرض سار او معد: وهذا السبب يعود تحقيقاً للمصلحة العامة فاذا كــان

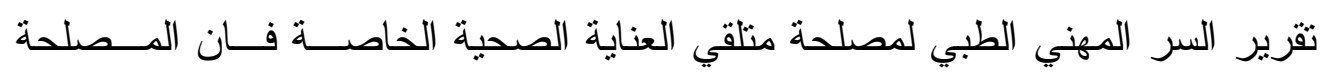
العامة ترجح عليها لذا اوجب نظام مز اولة المهن الصحية على المدــارس الـصحي افثناء السر عند اثتباهه في اصابة المريض بمرض معد او مرض سار او مسرض هرض

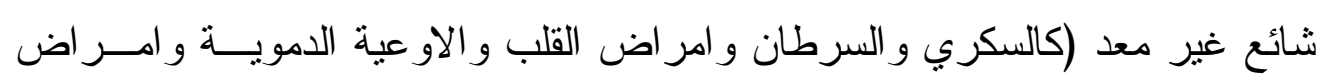

(1) عبد الحميد الثواربي، شرح قانون العقوبات،دراسة مقارنة في الشريعة الاسلامية، منشاة

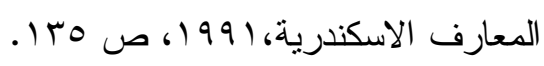


مشابهة بمكن ان نتكل خطر اً على الصحة العامة). الابلاغ عن حالات الو لادة و الحالة الصحية للمولود وتسجيل كافة المعلومات المتعلقة بهذه الحالة بالسجل المعد لذلك الاب و الام وديانتهما وتاريخ وساعة الو لادة. ثانياً: حالات الافثناء لتحقيق سير العدالة و الدفاع عن النفس. * حالة صدور قر ار من جهة قضائية بتكليف الممارس الصحي لــلادلاء بالـشههادة، عن حالة تتعلق بالمريض الذي قدم لهالعناية فان الادلاء بالثهادة عندها واجب وذلك

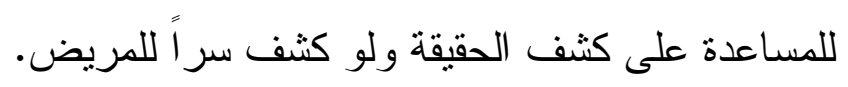
حالات دفاع الممارس عن نفسه لمواجهة اتهام وجهه اليه المريض أو ذووه يتعلق

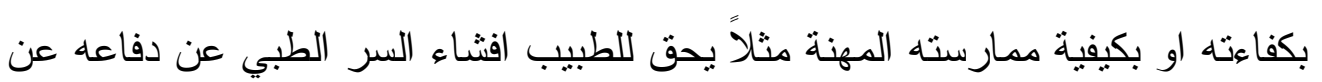

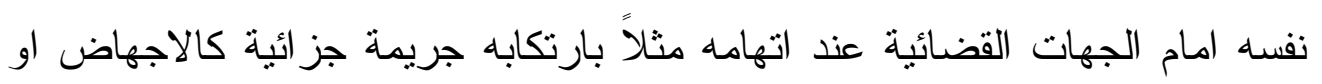
الاغتصاب او خطأ في العلاج. حالات تكليف الممارس الصحي من قبل هيئة قضائية لتقديم تقرير خبرة في شأن من شؤون تخصصه عن حالة محددة. ثالثاً: حالات رضاء المريض“صاحب السر" او لمنفعته. من الحالات التي يجوز لممارس الصحي أن يفشي السر المهني في حال أذن صاحب السر له بذلك بشرط أن يكون الرضاء صادر عن ار ادة حرة و ادر الك سليم و أن يكون كتابة.

كذلك يجوز الافثاء عن السر عندما توجد ظروف تقرض على الممارس الصحي (لا

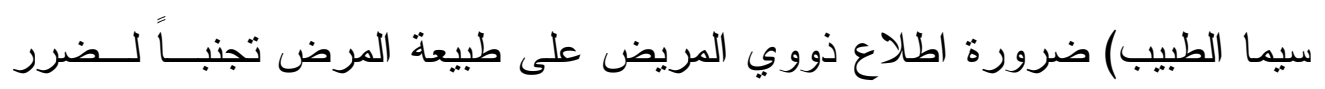
أكبر من الضرر الذي ينتج عنه الافثاء أو كان افثـاء السر يفيد في العلاج. رابعاً: و اجبات الزمالة الو اقعة على الممارس الصحي. * ككل المهن الحرة يقتضي أن تكون العلاقة بين الممارسين الصحيين على قدر من 
التعاون و الثقة المتبادلة، وان بيتعدوا عن كل ما من شأنه أن يــؤثر علــى مـستوى الاداء ويحطو ا من مستوى المهنة، كالمنافسات غير المشروعة و التخاطب غير اللائق و التمييز العنصري داخل المؤسسة الصحية وغير ذلك.

فعلى سبيل المثنال يمنع على الممارس الصحي الكيد لزميله و اثثــاعة اخبــار عنـــه تفضي إلى الانتقاص من كرامته او مكانته العلمية او الادبية، كما يحظر عليه الاتيان

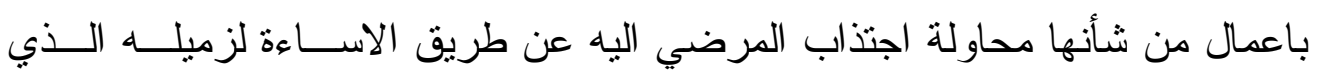

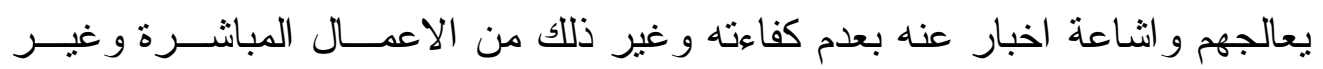

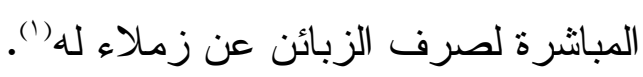

على الممارس الصحي الذي يحل محل زميله في تقديم الخدمات الصحية لمرضــاه،

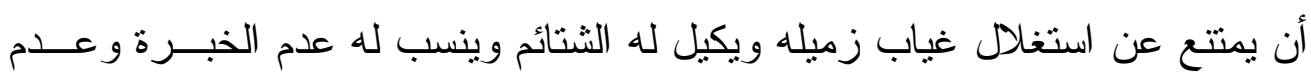

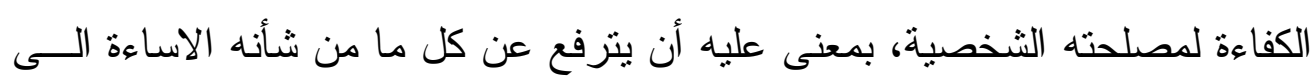
زميله في ممارسة مينته.

يقع على الممارس الصحي الذي يحل محل زميله فــي تقــديم الخــدمات الــصحية لمرضاه أن يطلع على ملف المريض بدقة وعلى الاجر اءات و العلاجات التي بــــأها

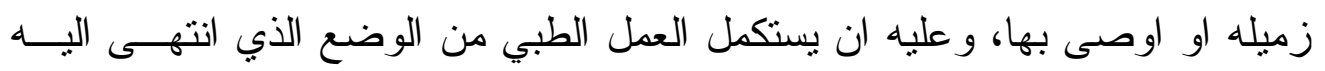

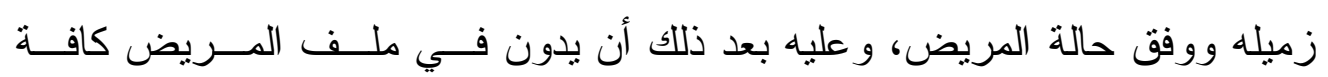

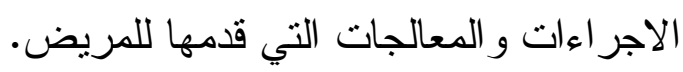
المحظور ات الو اقعة على الممارسين الصحيين. القى نظام مز اولة المهن الصحية و لائحته التتفيذية العديد مـن المحظــورات التـي يتوجب على الممارسين الصحيين التقبد بها تحت طائلة المسؤولية الجزائيـــة غالبــاً، نذكر من هذه المحظور ات او الممنوعات الامور التالية:

(1)) عبد الحميد الثواربى،مسؤلية الاطباء و الصبادة و المستشفيبات،المدنية و الجنائية، منشأة

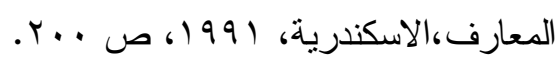


عدم اتباع طرق التشخيص و العلاج غير المعترف بها علمياً، على الممارس الصحي

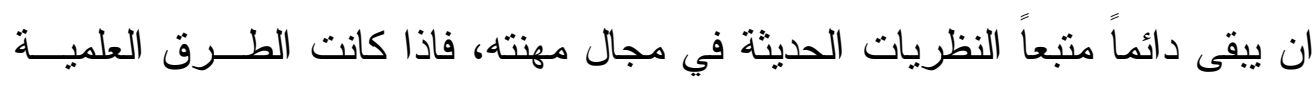
القديمة المتبعة اثبت ضررها اكثر من نفعها فيجب التخلي عنها، كذلك يجب التخلـي

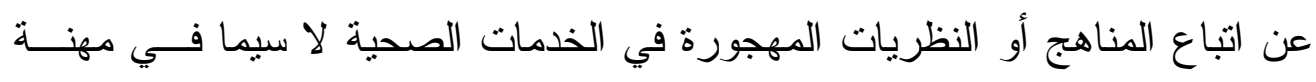

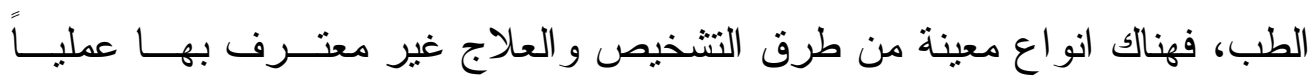

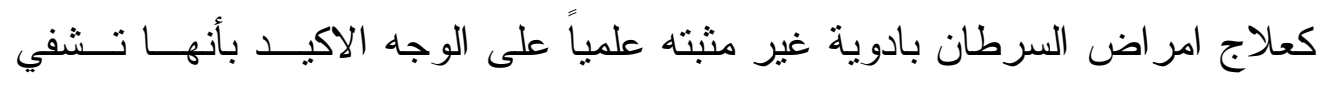
المريض او مجهولة المضاعفات المنزتبة عنها.

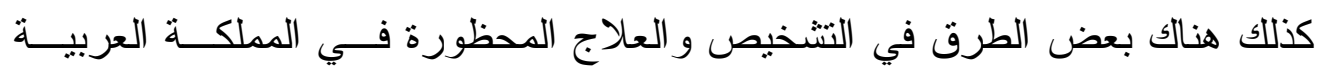
السعودية اما لانها مخالفة لاحكام الثريعة الاسلامية او ان التطبيقات العلمية اثتبــت

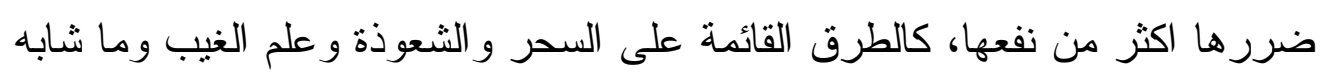
ذلك.

الا ان اللائحة التنفيذية لنظام مز اولة المهن الصحية في المملكــة اجـازت ممارســـة

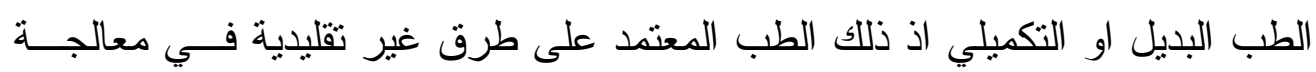

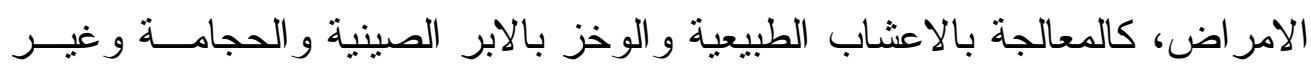

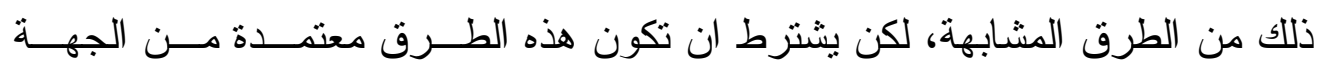

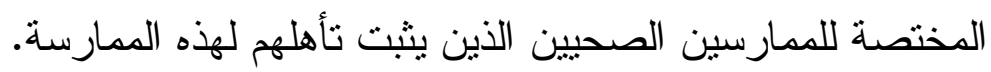

يحظر على الممارس الصحي القيام بعمل يتجاوز اختصاصه او امكاناتــه، فمـثنالُْ لا يجوز للطبيب العام (غير المتخصص) ان يقوم بعمليات جر احية اذا كان في ظروف

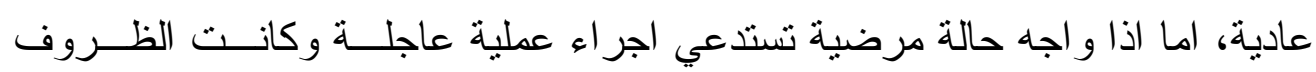

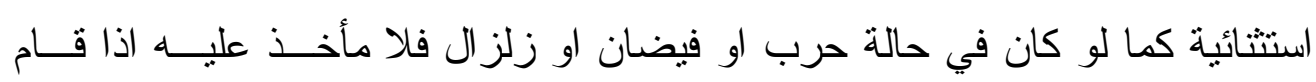

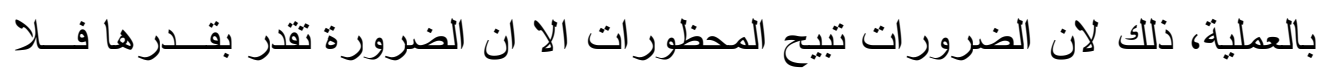
يجوز التذرع بحالة الضرورة لاتيان عمل يتجاوز امكانيته او اختــصاصه اذا كــان 


\section{بالمقدور بذل جهذ معقول لاحالة المريض الى الجهة الصالحة(1).}

في هذا السياق تلتزم المؤسسة الصحية التي يعمل لديها الممارس الصحي ان تعسرف الصلاحيات السريرية و الوصف الوظيفي لهذا الممارس الصحي ومؤهلاته وخبرتــه، لهيه بمعنى آخر ان كل ممارس صحي تكون صلاحياته معروفة ومحددة حسسب خبرتــــ وتخصصه لاى جهة العمل.

يمنع عن الممارس الصحي الاعلان عن نفسه و الدعايه لشخصده مباشرة او بالواسطة وذلك في غير الحالات التي سمحت بها اللائحة التنفيذية لنظام مزاولة المهن الصحية.

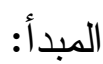

أن المهن الصحية تحمل في طياتها رسالة سامية ألا وهي المـسـاهمة فـــ تحقــق

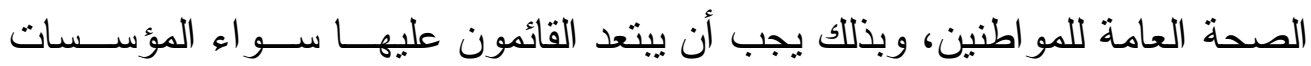

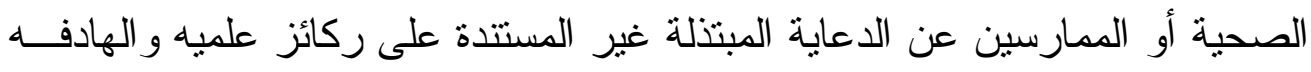
فقط اجتذاب الزبائن وتحقيق اكبر قدر ممكن من الارباح ضاربين بعــرض الحــائط كافة القيم الاخلاقية.

إلا أن النظام أتاح للممارس الصحي الاعلان عن نفسه في حالات محددة منها: الاعلان عن التخصص المرخص له به، أي الاعلان عن مهنته الحاصل فيها على اذن بمز اولة المهنة. الاعلان عن العودة من الاجازة. الاعلان عن تغيير مو اعيد الدوام.. يحظر على الممارس الصحي أن يسجل على اللوحات الاعلانية الخاصة به، أو على بطاقات التعريف به، أو على دفتر الوصفات الطبية، او الاعلانات التي ينظمها، ان

(1) عبد الحميد الثواربى، المرجع السابق ص می r. 
يسجل القاباً او تخصصات لم يحصل عليها وفقاً للأصول. يمنع الممارس الصحي ان يمارس أكثر من مهنة صحية واحدة وان كــان حاصــلاً

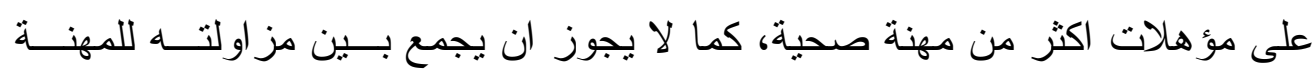

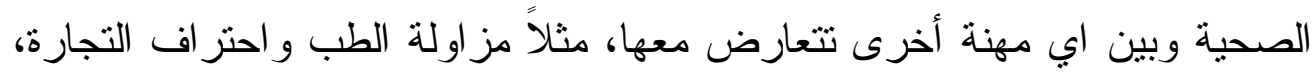
او مز اولة الصيدلية وقيادة سيارة بالاجرة.

يحظر على الممارس الصحي ان يطلب عطية (منفعة ) او يقبلها او يأخذها أياً كانت

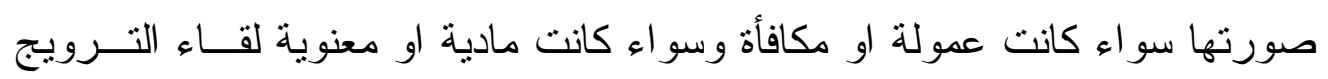

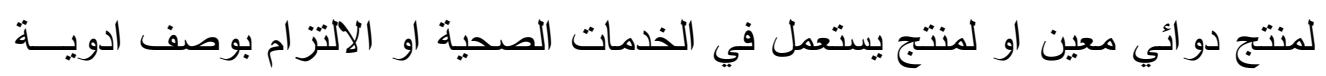

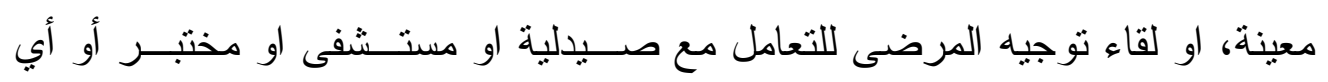
مؤسسة صحية خاصة اخرى محددة، فعلى الممارس اخبار المريض فقط بالامــاكن التي تتو افر فيها الخدمة دون الترويج لها ومن ثم يجب ترك الخيار له. يحظر على الممارس الصحي اجراء الفحوصات او تقديم العلاج سواء اكان بالمقابل او بالمجان في الصيدليات او الاماكن غير المخصصة لذلك الا في الحالات الطارئة،

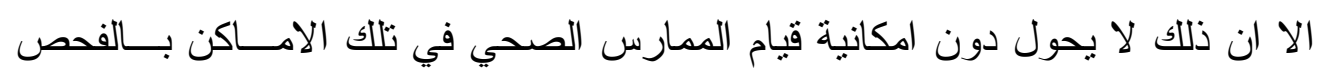
و العلاج على سبيل المشورة في الحالات التي تقتضي ذللك (1). يمنع على الممارس الصحي استخدام اثخاص لمساعدته في تقديم العناية الصحية غير مرخص لهم بمز اولة المهنية، على سبيل المثال لا يجوز للطبيب استخدام عاملة في عيادته كممرضة غير حائزة على شهادة التمريض و اذن مز اولة المهنة. كذلك الامر لا يجوز للصيدلي استخدام عامل لديه في الصيدلية لبيع الادوية وتركيبها دون ان يكون صيدلي مجاز وحاصل على اذن مز اولة المهنة. كما يمنع عليه ايضا تقديم اي مساعدة ذات صلة بالمهن الصحية لـشخص يمسارس (1) د. عبد الرؤوف عبيد، جرائم الاعنداء علي الاشخاص والامو ال،دار الفكر العربي، مصر،

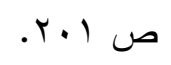


مهنة صحية بطريقة غير مشروعة مع علمه ان هذا الثخص يمارس المهنة الصحية بصورة غير مشروعة.

يحظر على الممارس الصحي الاحتفاظ في مقر عمله بالادوية و اللقاحات خلافاً لمـــا

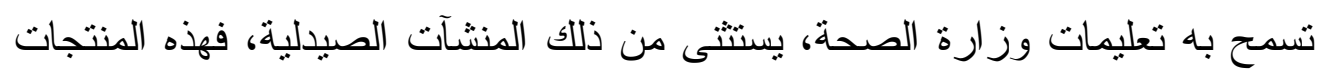
لها اثر كبير على الصحة العامة اذا ما اسيع استعمالها وحفظها لذلك يجب الاحتفــاظ

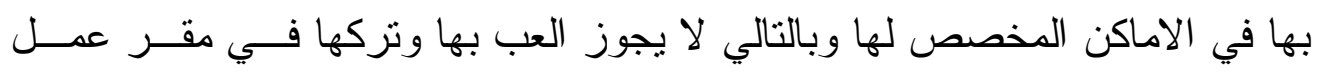

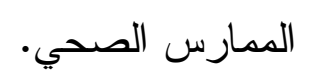

لا يجوز للممارسين الصحيين الاتجار بالادوية أي بيعها للمرضى تحــت اي شــكل

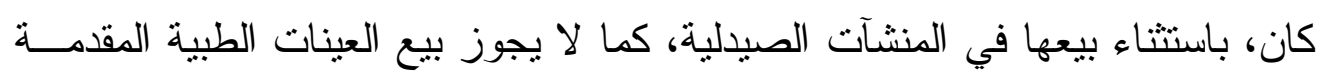

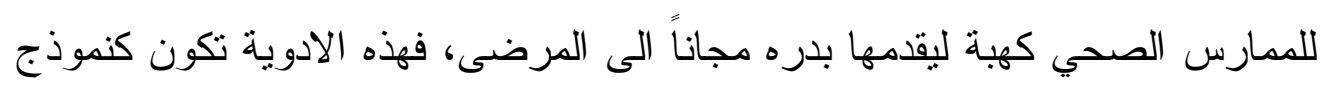

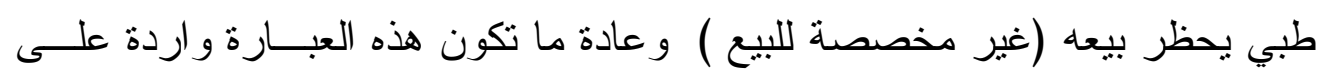

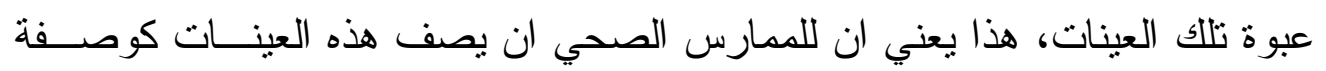

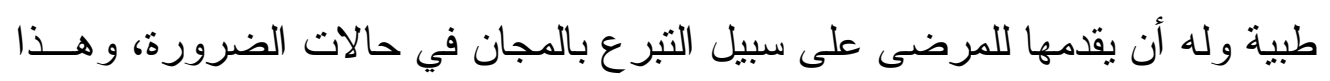
هو الحكم بالنسبة للأدوية الاسعافية.

يحظر على الممارس الصحي القيام بما يسمى القتل الرحيم وهي نظريـــة مــصدر ها

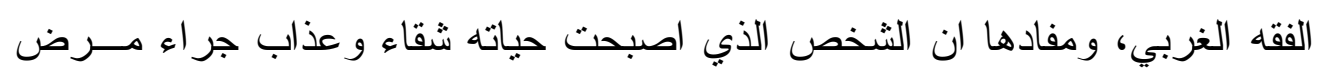

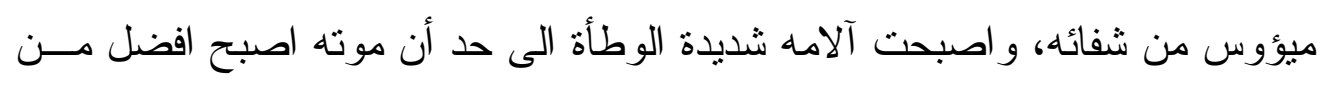

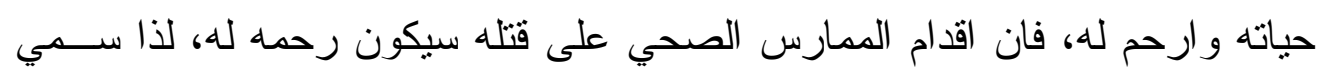
بالموت الرحيم او القتل شفقة، شرط أن بطلب المريض بالحاح بانهاء حياته، فاذا قام

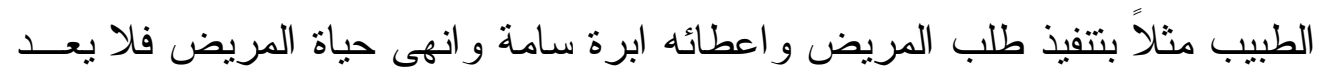
الطبيب قاتلاً بنظر القانون، هذا في القو انين التي تعتمد هذه النظرية. الا ان المملكة العربية السعودية لا تأخذ بهذه النظرية وجميع الدول العربية كذلك

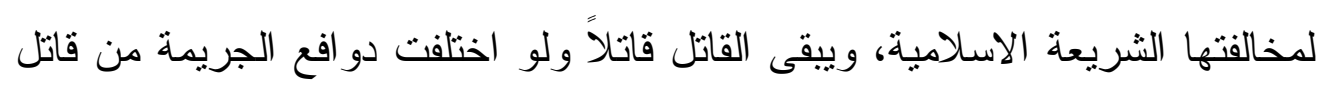


الى آخر فسو اء كان القتل بدافع الثفقة او بدافع الانتقام فالامر سيان (1). وقد اكد النظام السعودي على ذلك في المادة 9 المن نظام مز اولة المهــن الــصحية

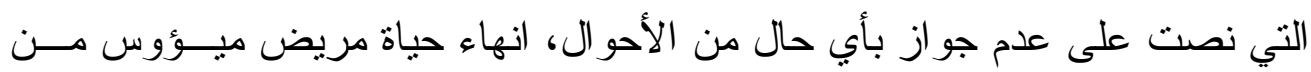
شفائه طبياً ولو كان بناء على طلبه أو طلب ذويه.

يحظر على الممارس الصحي السعي من أجل حصول المريض على اي ميزة او منفعة غير مستحقة او غير مشروعة.

تتعدد صور المنفعة فقد تكون مادية مثلاً تقديم اجهزة علاجية او ادوية اضافية لــبس بحاجة اليها المريض، وقد تكون معنوية مثناً تأمين غرفة له له مستقلة للتتويم، او تأمين اكثر من ممرضة للاعتتاء بمريض على مدى ع r ساعة كل ذلك بـشرط الا يكــون

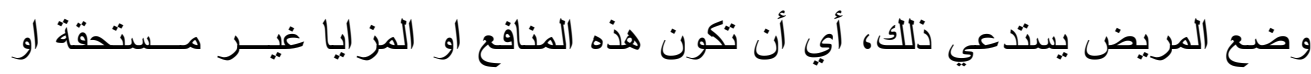
غير مشرو عة.

يحظر ايو اء المريض في غير الاماكن المعدة لذلك، حيث ان كافة المنشآت الــصحية

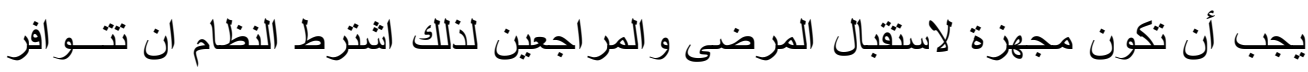
في مباني المؤسسات الصحية الغرف و التجهيـز ات اللازمــــة لاداء مهمـــة العنايـــة الصحية، يتزتب على ذلك وجوب التزام الممارسين الصحيين و المنـشآت الــصحية بايو اء المرضى في الاماكن المخصصة لهم كل بحسب حالته.

على سبيل المثال لا يجوز وضع المريض الذي يعاني من مرض معد في الغرف

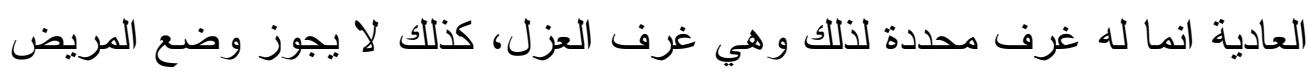
في غرف ليس فيها شبابيك للتهوئة كافية او الانارة فيها غير ملائمة كما لا يجوز اجر اء العمليات بغرف غير مجهزة ومخصصة للعمليات.

الا ان ذلك لا يحول في الحالات الطارئة او الاسعافية المستعجلة وضع المريض في

( ()) د. عبد الرؤوف عبيد المرجع السابق، ص 9^r. 
غير المكان المخصص له، على اعتبار الضرور ات تبيح المحظور ات. بناء عليه اذا وردت حالة طارئة لقسم الطوارئ في المستشفى ووضــعها لا يحتمـلـ التأخير في تقديم الاسعافات الاولية فاذا كانت غرف المستشفى ممتلئة وكذلك أســرّة

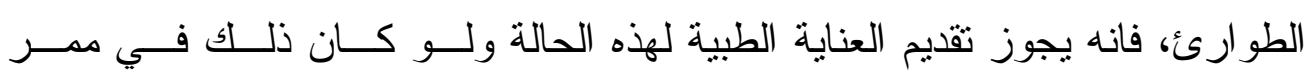

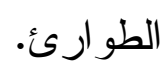

يحظر على الممارسين الصحيين استخدام اجهزة كثف اوتـشخيص او اي اجهـزة اخرى او علاجات ممنوع استخدامها في المملكة لمخالفتها احكام الثريعة الاسلامية،

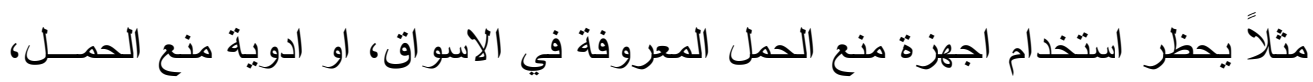

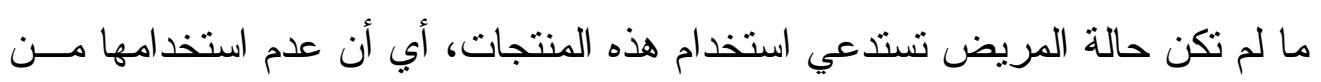

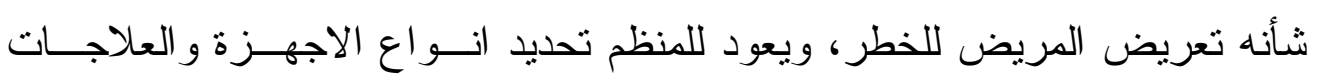
الممنوع استخدامها في المملكة.

يحظر على الممارس الصحي اصدار تقارير غير صحيحة أو مبالغ فيها لا ســيما اذا كانت بناء على طلب المريض للحصول على اجازة مرضية غير مستحقة او شـــهادة صحية غير مطابقة للواقع، او للحصول على تقرير عن حالة مريض اصيب بحادث

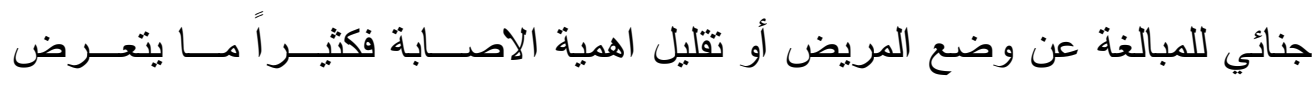

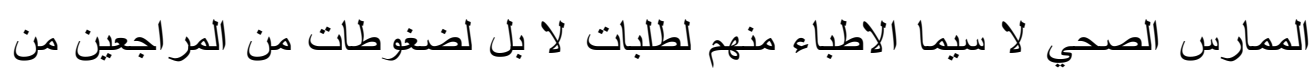

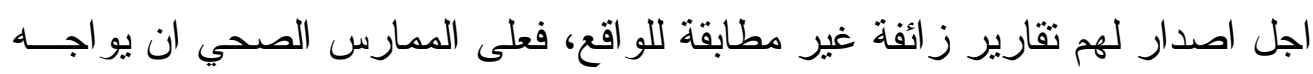
ذلك و لا يصدر تقرير الا وفقاً لما يمليه عليه ضميره ومهنته الصحية (1).

(1) - د. اسامة عبد اله قايد، المسؤلية الجنائية للاطباء،دار الانهضة، القاهرة، 999 1، ص 


\section{المبلبب الثاني}

محظورات تتعلق بالاطباء فقط من المهمارسين الصسحيبن(').

المحظور ات المتعلقة بالصبادلة فقط.

ارسى نظام مزاولة المهن الصحية جملة من المحظورات تتعلق بمهنة الصيدلة وبالصيادلة وهي التالية:

- يمنع على الصيدلي ان يكون مدير اً مسؤو لاً من صيدلية واحدة، بناء عليه اذا كــان

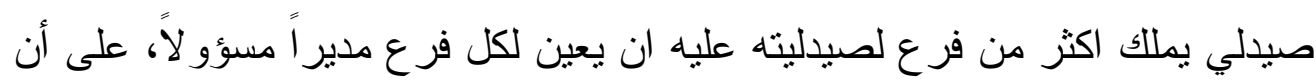

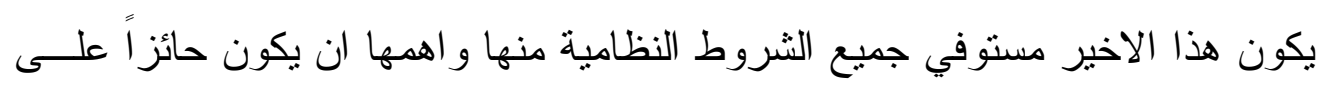
اذن مز اولة الصيدلة، وان يلتزم بالموجبات و المسؤوليات المحددة في نظام المنـشآت الصيد لانية و المستحضر ات الدو ائية و لائحته التنفيذية.

يحظر على الصيدلي صرف اي دو اء الا بوصفه طبية، لا سيما الادوية التـي فيهــا

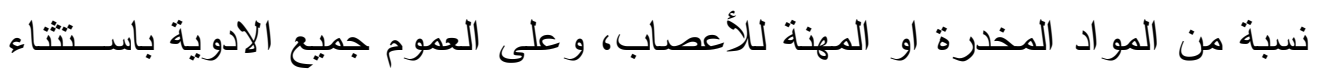
تلك الادوية التي تحددها وزارة الصحة، على سبيل المثال البانـدول و البر اسـتيمول

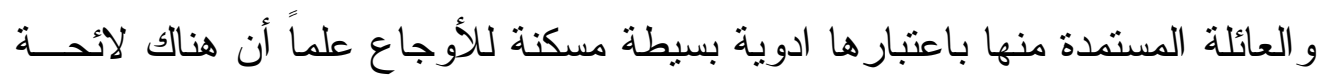

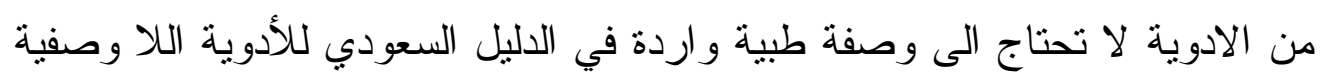

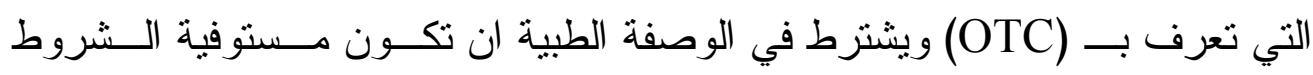

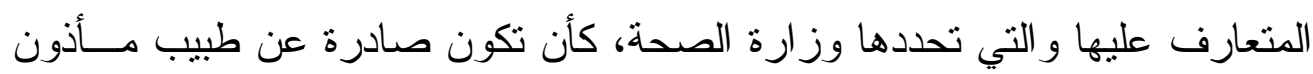

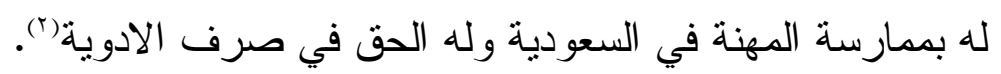

لا يجوز للصيدلي مخالفة محتوى الوصفة الطبية دون مو افقة الطبيب الذي اعتمدها،

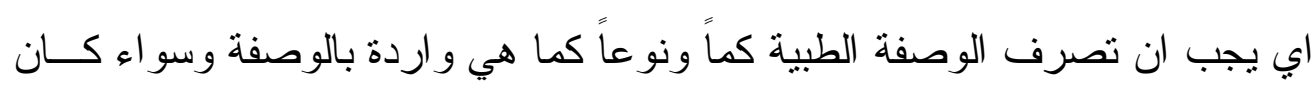

(1) (1) د. اسامة عبد الله قايد، المرجع السابق، ص .ro.

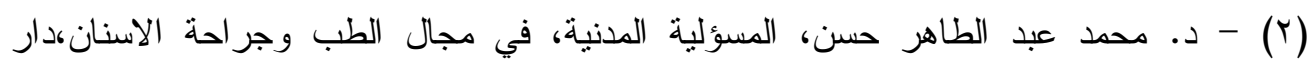

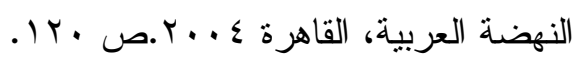


الدواء جاهز اً أو مركباً، في هذا السياق اجاز نظام مزاولة المهن الصحية للــصبدلي

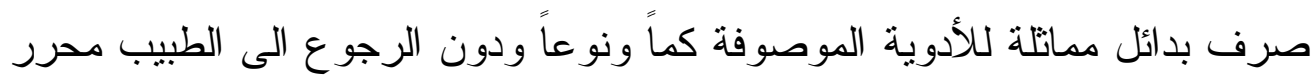
الوصفة شرط ان تكون تلك الادوية مسجلة في وزارة الصحة ويكون سعرها مساوياً

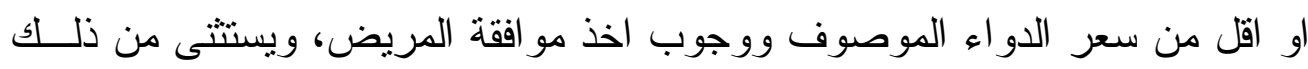
الادوية ذات المجال العلاجي الضيق (Narrow Therapeu c Index) وتلك التـي مني

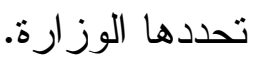

يحظر على الصيدلي نكرار صرف الوصفة الطبية الا اذا كانت الوصفة الطبية تتص

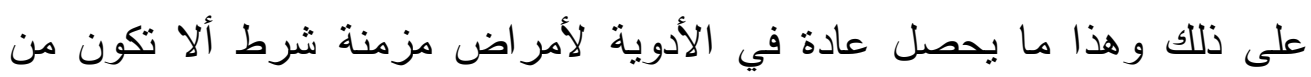

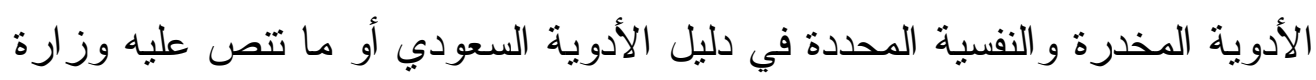
الصحة.

لا يجوز للعاملين في الصيدلة من فنيين وغيرهم وطلاب الــصيدلة المتـدرجين ان

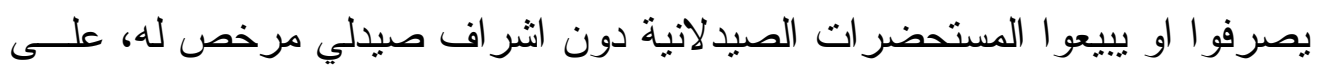

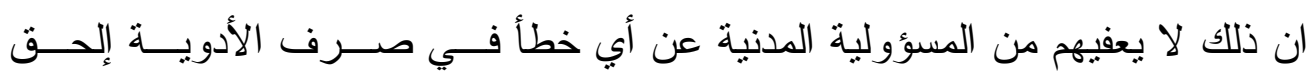
الضرر بالزبائن.

الأصل أن الصيدلي لا يجوز له الامتتاع عن بيع الدواء للزبائن اذا كان الطلب مشروعاً، الا انه استثناءً من ذلك عليه الامتتاع عن صرف الدو اء في حالتين: اذا ظهر له خطأ في الوصفة الطبية عندها عليه استيضاح رأي الطبيب الذي حرر الوصفة.

إذا تبين له عدم صلاحية الدو اء للاستعمال، عليه توضيح ذلك للطبيب الــذي حـرر

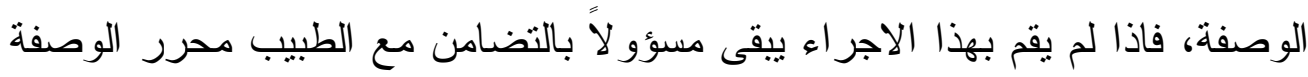

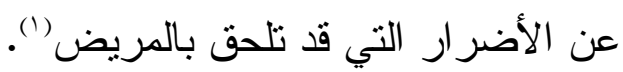

(1) - د. محمد عبد الطاهر حسن، المرجع السابق، ص • 1 ا. 


\section{المطلب الثالث}

\section{المسؤولية المهنية للمهمارس المسحي"'.}

القاعدة العامة في العمل غير المشروع (الفعل الضـار) كمصدر من مصادر الالتــز ام

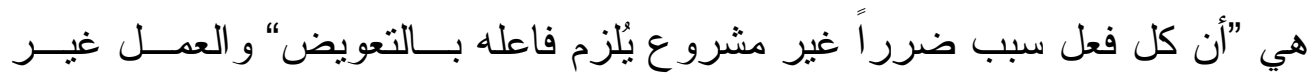

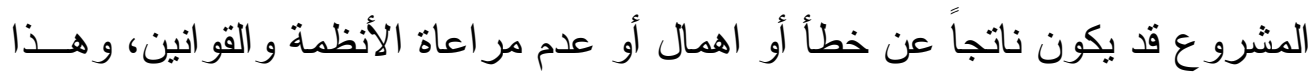
ما بسمى في العلم القانوني بالمسؤولية، وتتقسم المسؤولية الى مسؤولية مدنية (عقدية

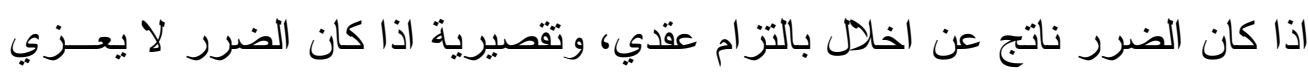
إلى اخلال بالتز ام عقدي). ومسؤولية جنائية اذا كان الثخص ارتكب فعلاً يجرمه القانون. ومسؤولية تأدييية اذا اخل صاحب المهنة او الموظف بأنظمة المهنة او الوظيفة التابع لها.

وقد يحدث ان تجتمع المسؤوليات الثلاث بارتكاب فعل و احد كما لو قام طبيب غيــر مختص بعطية جر احية لمريض دون اذنه فارتكب خطاً فادحاً سبب ضرر اً بليغاً له. أولاً: المسؤولية المدنية:

ان المسؤولية المدنية هي التزام المدين بتعويض الضرر الذي يترنب عن اخلاله بالتز ام يقع عليه. تتقسم المسؤولية المدنية للممارس الصحي الى نوعين الاولى مسؤولية عقدية وهـي ناتجة عن الاخلال بالالتز امات العقدية (بين الممارس الــصحي و المــريض او بــين المريض و المؤسسة الصحية الخاصة) و الثانية مسؤولية تقصيرية وهي لا تستتد إلـى عقد بل الى الاخلال بو اجب الحيطة والحــذر (أو اخلال بالتز ام قانوني)، و اذا كان الاتجاه الفقهي و القضائي مجمع على قيام مسؤولية الممارس الصحي بشكل 
عام و الطبيب بشكل خاص عند خطئهم او اهمالهم او تقصيرهم اثتاء تقديم الخدمة الصحية للمريض.

الا أن تكييف تلك المسؤولية فيما اذا كانت عقدية او تقصيرية امر مختلف عليـه، الا أن الر أي الر اجح يرى في تكييف مسؤولية الطبيب (و الممارس الصحي) عن اخطائه المهنية هي مسؤولية عقدية، و اخذ بذلك كل من القضاء الفرنسي و المصري. حتى تقوم مسؤولية الطبيب او الممارس الصحي لا بد ان برتكب ثمة خطأ ينتج عنه ضرر و اثبات علاقة السبيية بين الضرر و الخطأ. الخطأ الطبي او خطأ الممارس الصحي الذي يتحمل عنه المسؤولية هو انحر اف فـي سلوك ايجابي (فعل) أو سلبي (امتتاع عن فحل) من قبل الطبيب او الممارس الصدي لهاي يتمثل هذا الخطأ بعدم قيام الطبيب او الممارس الصحي بالالتز امات الخاصـــة التـي التي

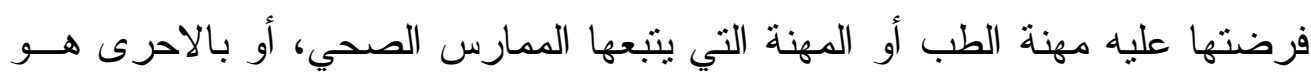
كل تقصير في مسلك الطبيب.

و الالتزام الذي يقع على الطبيب أو الممارس الصحي من حيث المبدأ هو التزام ببذل

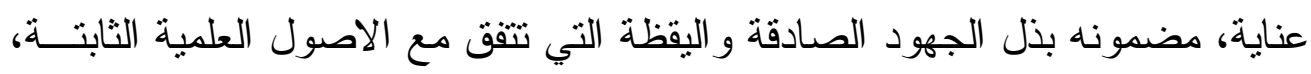
و التي تتفق مع الظروف القائمة بهدف شفاء المريض وتحسين حالته الصحية، وكـلـل اخلال بهذا الالتز ام يشكل خطاًُ طبياً يثير مسؤولية الطبيب او الممارس الصحي (1). يقاس ما اذا كان فعل الطبيب او الممارس الصحي يشكل خطأ من عدمــه، بمعيـار

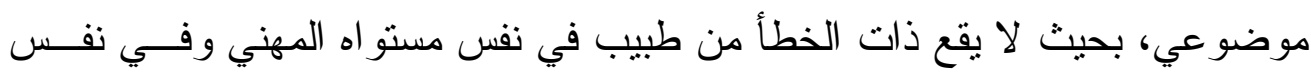
الظروف التي احاطت بالطبيب أو الممارس الصحي المسؤول، أي أن القاضي فـي في سبيل تقدير خطأ الطبيب أو الممارس الصحي في علاج المريض او تقــديم العنايــة الصحية له يقيس سلوكه على سلوك ممارس من مستو اه المهني المتوسط (r).

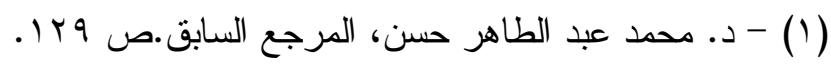

(r) نصت المادة بr من نظام مزاولة المهن الصحية على ان "النز ام الممارس الصحي الخاضع 
يكون التز ام المدين بتحقيق نتيجة اذا كان المطلوب منه القيام بعمل معين بذاته فعـدم

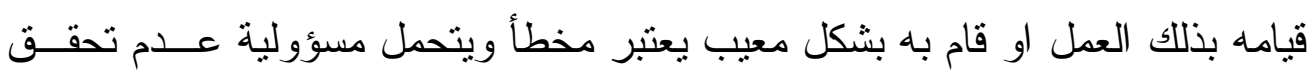
النتيجة المرجوة، كالتز ام الناقل بنقل البضائع من مكان معين الى مكان آخر . أما اذا كان المطلوب من المدين بذل عناية لتحقيق النتيجة المرجوة دون ان يــضمن

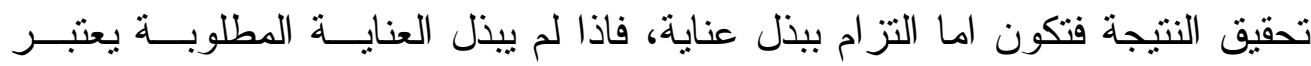
مخطئًا ويتحمل مسؤوليته اما اذا بذل العناية المطلوبة فلا مسؤولية عليه حتى ولو لم لماية فئل

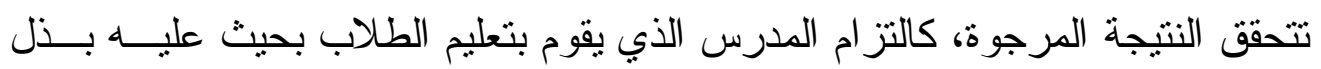
العناية اللازمة لانجاحهم دون ان يضمن تحقق النجاح، و هذا هو التز ام الطبيب تجــــاه

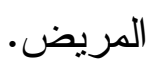
أهمية التقرقة بين الالتز امين: - مين تكمن اهمية التفرقة بين الالتزامين في عبء الاثبات ففي التزام بتحقيق نتيجة يكفي ان يثبت الائن عدم تحقق النتيجة المرجوة وبالتالي يفترض خطأ المدين بعدم تحقق التق لهن النتيجة، فلا يسنطيع نفي مسؤوليته الا اذا قام الدليل على وجود السبب الاجنبي الذي لئي منعه من تحقيق النتيجة.

و السبب الاجنبي هو القوة القاهرة او خطأ الدائن او خطأ الغير (1). في حين أنه في التزام ببذل العناية يقع على عاتق الدائن اثبات تقصير المدين وعــدم

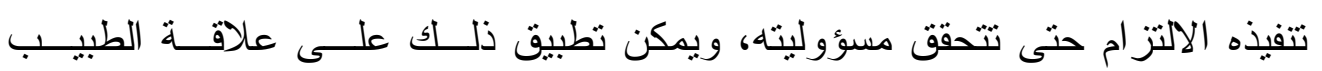

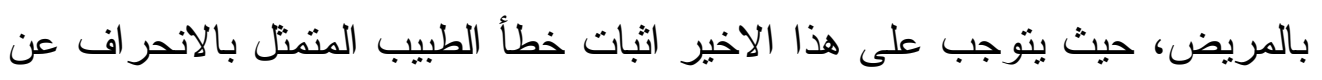
الاصول الطبية المستقرة في علم الطب بالاضافة الى اثبات الضرر و العلاقة الــسبية

لاحكام هذا النظام هو التزام بيذل عناية" يقظة تتقق مع الاصول العلمية المتعارف عليها.يتضح من

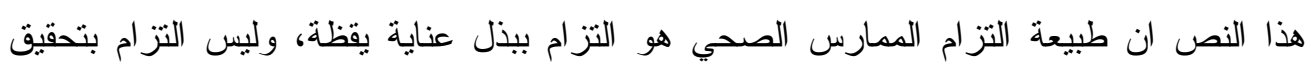
نتيجة. (1) د. اسامة عبد الله قايد، المرجع السابق، ص ه. ". 
بين الخطأ و الضرر • - مبر

فالاطباء و الممارسون الصحيون يقع عليهم بالمبدأ التز ام ببذل عناية صادقة ويقظــــة

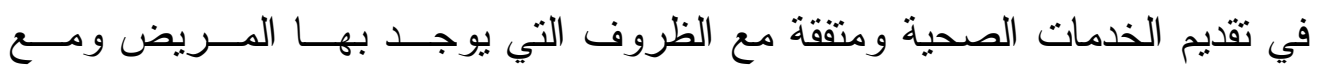

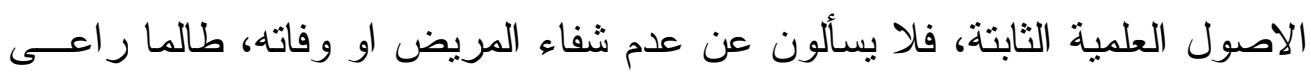
في تقديم الخدمات الصحية القو اعد المهنية المستقاة من مهنة الطب او المهن الصحية

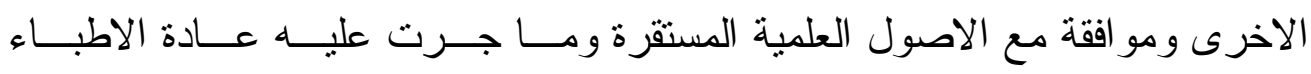
و الممارسين الصحيين في ذات الظروف. فيسأل الطبيب او الممارس الصحي عن كل تقصير في مسكله الطبــي لا يقـع مــن طبيب يقط في مستو اه المهني وجد في نفس الظروف الخارجية الني احاطت بالطبيب (او الممارس الصحي) المسؤول، كما يسأل عن خطئه العادي أياً كانت جسامته. الضرر

الضرر هو بصفةعامة المساس بمصلحة المضرور بحيث يصير المضرور في وضع اسو أ مما كان عليه قبل وقوع الخطأ، و الضرر قد يكون مادياً أي ماساً

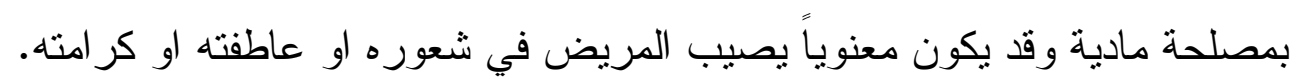
وقد اناط نظام مزاولة المهن الصحية بالهيئة الثرعية الــصحية تقـدير التعــويض

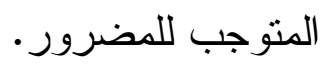
علاقة السبيبة: معناها وجود ر ابطة مباشرة بين الخطأ الذي ارتكبه المسؤول و الضرر الذي اصاب المضرور، فاذا لم تتو افر هذه العلاقة انتقت المسؤولية، واثبات العلاقة السببية

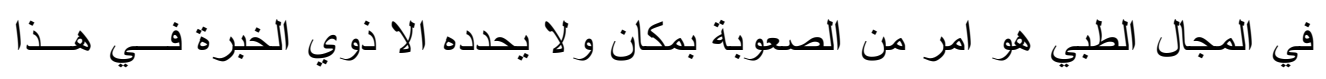

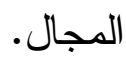

وتتتفي رابطة السببية بين الخطأ والضرر اذا توافر سبب اجنبي ادى الى حدوث الضرر يتمثل السبب الاجنبي بالقوة القاهرة او خطأ المريض أو خطأ الغير. 
و القوة القاهرة هي حدث مفاجئ لا يمكن توقعه و لا يمكن دفعه، كما لو تفي مريض بالقلب تحت العملية جر اء حدوث زلز ال.

وكذلك الامر تتتفي مسؤولية الطبيب او الممارس الصحي اذا وقع خطأ من المريض

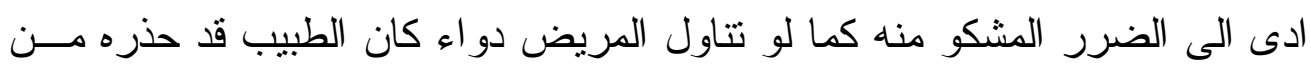
تتاوله.

اضافة الى ذلك فقد ذكرت المادة السابقة عدة صور للخطأ المهني وهي واردة على سبيل المثال بدليل ما ورد في ذيل المادة rV بقولها "ويعد من قبيل الخطأ المهني الصحي ما يأتي، هذه الصور هي التالية'(1): ا. الخطأ في العلاج او نقص المتابعة(؟).

r. الجهل بأمور فنية يفترض فيمن كان في منل تخصصه الالمام بها. r. اجر اء العمليات الجر احية التجريبية وغير المسبوقة على الانسان بالمخالفة للقو اعـــ المنظمة لذلك. ع. اجر اء التجارب او البحوث العلمية غير المعتمدة على المريض. م. اعطاء دو اء للمريض على سبيل الاختبار . 7. استخدام آلات او اجهزة طبية دون علم كاف بطريقة استعمالها او دون اتخاذ الاحتياطات الكفيلة بمنع حدوث ضرر من جر اء هذا الاستعمال.

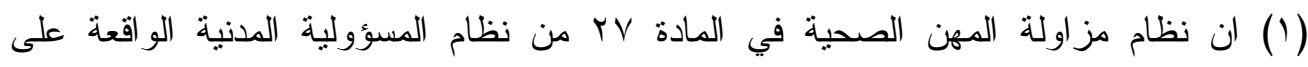

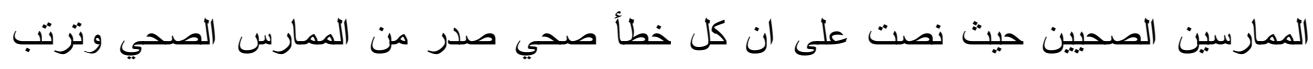

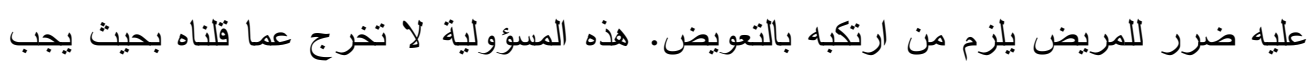

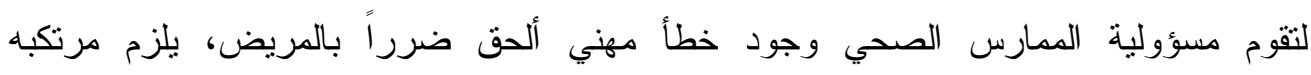
بالتعويض. (ץ) د. علي حسين نجيدة، التزامات الطبيب في العمل الطبي، بدون طابعة دار النهضة العربية،

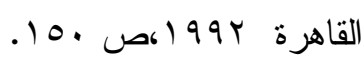


و ابطل المنظم السعودي كل شرط وارد في العلاقة التعاقدية بين الممارس الـصحي

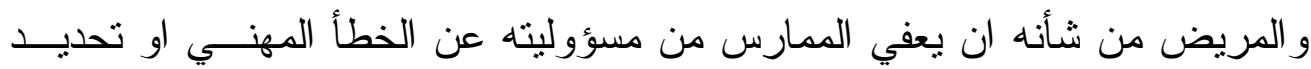
مسؤوليته بسقف معين لا يجوز تجاوزه. بعض التطبيقات عن الخطأ المهني الطبي (1). الخطأ في التشخيص: يسأل الطبيب عن الاخطاء في التشخيص اذا كانــت نتطــوي

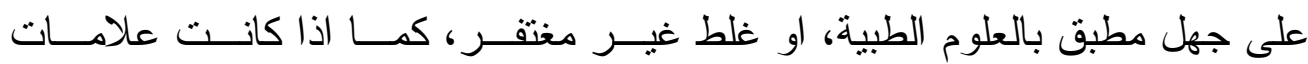
و اعر اض المرض من الظهور بحيث لا تقوت على طبيب منل الذي قام بالتشخيص. ويسأل أيضاً اذا كان خطؤه في التشخيص راجعاً الى عدم استعمال الوسائل العلميـــة الحديثة التي اتفق على استخدامها في مثل هذه الاحــو ال، كالـسماعة او الاثــعة او الفحص المجهري و التحاليل المخبرية و الفحوصات الميكروسكوبية، و لا يعفى الطبيب

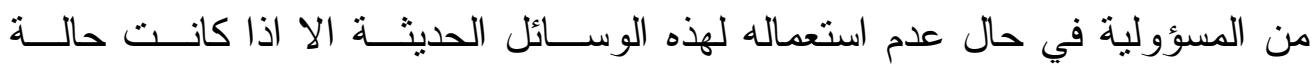

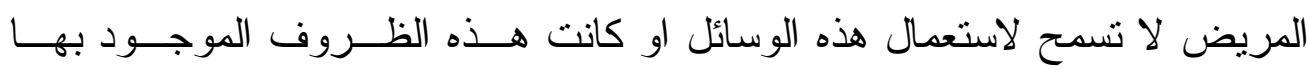
المريض لا تؤهل لذلك كوجوده في مكان مجهور او منعزل. لهان. كما تقوم مسؤوليته اذا استعمل وسائل مهجورة او طرفاً طبياً قديمة وكان من شــأن هذه الطرق الاضر ار بالمريض.

الخطأ في العلاج: تأتي هذه المرحلة بعد التشخيص وهي وصف العلاج وتحديد الطريقة الملائمة له، فيجب ان يكون هذا الوصف للعلاج ضمن الاصول العلمية الثابتة و على الطبيب ان يبذل الجهود الصادقة واليقظة فيطريقة اختيار العلاج. فاذا كان الطبيب لا يسأل عن عدم تحقق شفاء المريض عند وصفه للعلاج لكن يسأل 
اذا لم ير اع الحد اللازم من الحيطة و الحذر في وصــف العــلاج، اذا ينبغــي عليــه. مر اعاة بنية المريض وسنه وقوة مقاومته ودرجة احتماله للمـــــاد الكيميائيــة التــي يحتويها الدو اءو التفاعل السلبي باعطاء دو ائين معاً. فيسأل الطبيب او الممارس الصحي اعطاء جرعة زائدة من الدواء ادت الى تفاقم وضعه الصحي.

ويسأل الطبيب ايضا اذا وصف الدواء او طريقة العلاج قبل اجر اء الفحوصات الاولية لاختبار حالة المريض و ادى ذلك الى الحاق الضرر بالمريض. يسأل الطبيب ايضـا اذا نقل دم الى مريض لا تتفق فصيلته مع فــصيلة المــريض او

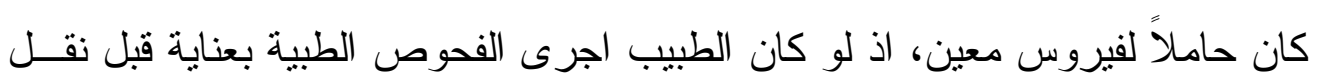
الدم لاكتشف ذلك بسهولة و امكن تجنب الاضر ار التي تلحق بالمريض. يسأل أيضا الطبيب الذي يصف دو اء ذات خصائص سامة دون ان يبين كمية العلاج الو اجب تعاطيها، كذللك الطبيب الذي يكتب الوصفة الطبية بصيغة غير مقروءة وتثير اللبس لاى الصيدلي فيصرف دو اءً مختلفاً يترثب عليه وفاة المريض.

العمليات الجر احية: على الطبيب قبل القبام باجر اء العملية الجر احية القيام بالفحص النشامل الذي تستدعيه حالة المريض وتقضتيه طبيعة الجراحة، فعليه ان يشرح للمريض باسلوب سهل ومفهوم طبيعة المرض وطرق المعالجة ونسبة النجاح

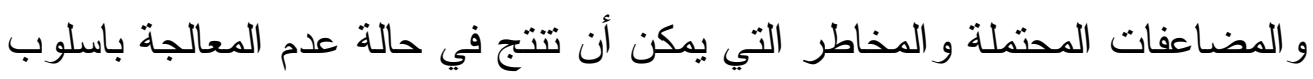
يتتاسب مع قدر اته الجسمية و العقلية و النفسية. فيلتزم الطبيب انثاء القيام بالعملية الجر احية بذل اقصى الجهود الطبية المتققــة مــع الاصول العلمية الثابتة.

كما يلزم ايضـا عند انتهاء العملية من متابعة حالة المريض متابعــة حثيتـــة ودقيقـــة 
فيسأل الجر اح مثناً اذا ترك قطعة قماش او المشرط في احشاء المريض('). استخدام الالات والاجززة الطبية: ان التقدم العلمي لا سيما في المجال الطبي استدعى استخدام معدات طبية حديثة تتطوي على بعض المخاطر على صحة الانسان اذا ما اسيء استعمالها، فعلى الممارس الصحي او الطبيب عليه استخدامه الات واجهزة سليمة لا تلحق الاذى بالمريض، ويجب ان يكون لديه العلم الكافي بطريقة الاستخدام، فيسأل الطبيب عن انفجاة آلة يرجع الى اهمال في اختيار مكان وضعها بين الالات الاخرى التي يستعملها. ويسأل الطبيب عن الأضرار التي اصابت المريض نتيجة سقوطه من فوق منــضدة الفحص بسبب هبوطها المفاجئ او عند صعوده او نزوله عنها. اثبات الخطأ المهني للطبيب او الممارس الصحي. عبء الاثبات: وفقاً للقو اعد العامة فان المريض "المدعي" هو الذي يقع عليه عبء اثبات الخطأ و الضرر و العلاقة السببية في دعوى المسؤولية على الطبيب و اذا كان اثبات الضرر لا صعوبة فيه الا ان اثبات الخطأ الطبي او المهني وعلاقة السبيية امر يكتنفه الكثير من الصعوبات.عندما يكون النزام الطبيب او الممارس الصحي التزام ببذل عناية يتوجب على المريض ان يثبت خطأ الطبيب او الممارس الصحي بان يقيم الدليل على اهماله او انحرافه عن اصول المهنة مع الاخذ بالاعتبار الظروف الخارجية المحيطة.

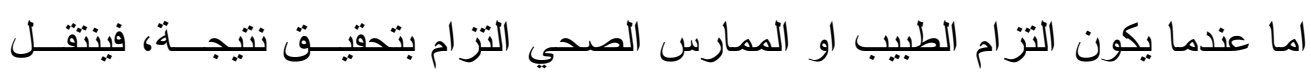

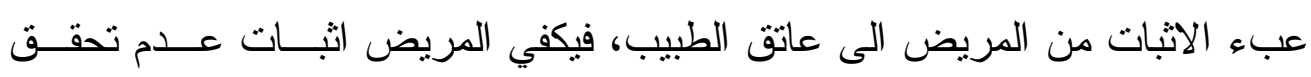

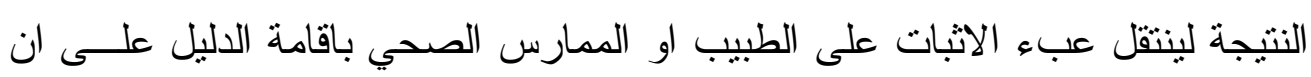

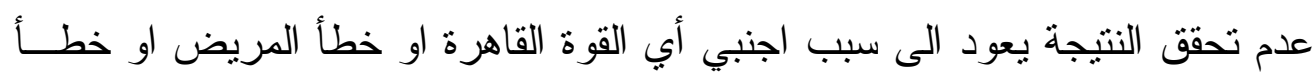
الغير

(1) د. احمد شريف الدين،الاحكام الثرعية للاعمال الطبية، القاهرة 999 (، ص YV9. 


\section{المبسحث الثنالث}

\section{المسؤولية المبزائية للمهمارسيسن المسحيين.}

\section{المطلب الاول

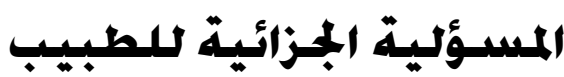

قد يرتكب الطبيب او الممارس الصحي اثثاء مز اولته المهنة خطــأ تجـــاه الاخــــين

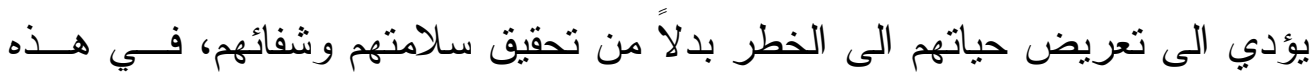

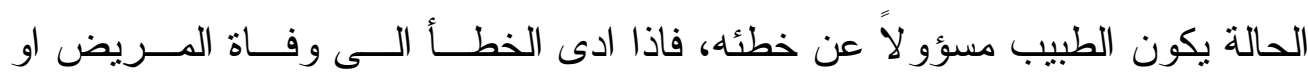
اصابته في جسمه او صحته فتكون مسؤولية الطبيب أو الممارس الصحي مـسؤولية جنائية غير عمدية، والخطأ في المسؤولية المدنية الذي حددناه هو ذاته الخطــأ فــي المسؤولية الجز ائية.

واذا كانت المسؤولية الجزائية للطبيب غالباً ما تقوم على الخطأ غير العدي، وبالتالي تكون جريمة غير عمدية الا انه اذا ارتكب فعلاً قصد منه الاضرار بالمريض تكون جريمته عمدية ومن باب أولى يعاقب عليها كالجريمة غير العددية وتكون عقوبتها اثند عادة.

مثال على ذلك كما لو دس الطبيب او الممرض او الصيدلي قصداً للمـريض الــذي يعالجه بدل الدو اء بغية ازهاق روحه.

في المملكة ان المسؤولية الجزائية وعقوبتها للممارسين الصحيين محددة بنـصوص خاصة في نظام مز اولة المهن الصحية، وبما ان النصوص الجز ائية يجب ان تفـسر

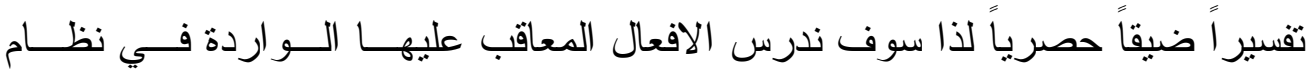

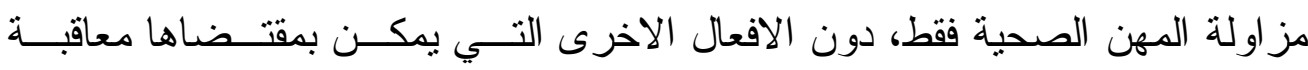

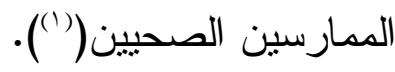

(1) فالأفعال التي نتكل أساس المسؤولية الجزائية للممارسين الصحيين وفق نظام مزاولة المهن 
نستتتج ذلك من مطلع هذه المادة الذي أتى بصيغة "مع عدم الاخلال بأي عقوبة أثنــــ منصوص عليها في أنظمة أخرى.

ان العقوبات الواردة في النص المشار اليه اعلاه هي عقوبات للأفعال التي يمكـن أن نطلق عليها الاخطاء غير العمدية، وهي السجن مدة لا تزيد عن ستة أثنهر وبغر امة

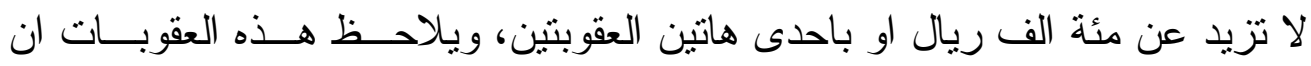

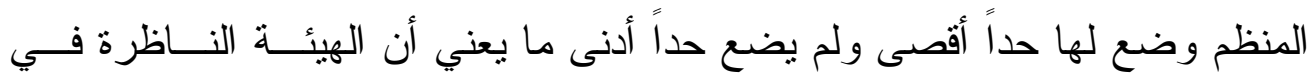

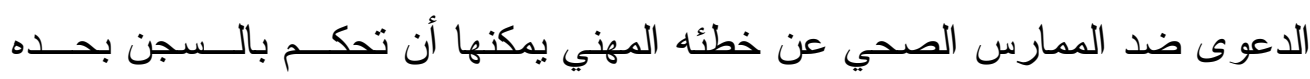

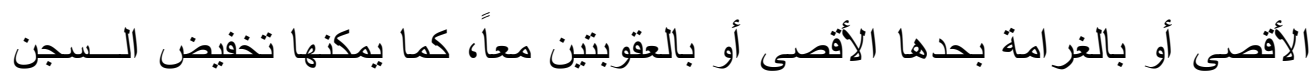

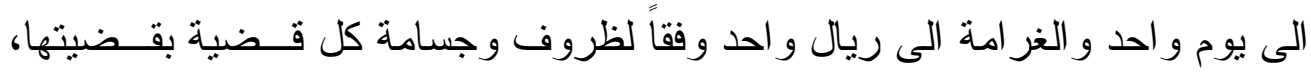
هذه العقوبة تطبق على الحالات التالية:

مزاولة المهنة دون ترخيص، المقصود بالمهنة هي المهنة الصحية ابي على

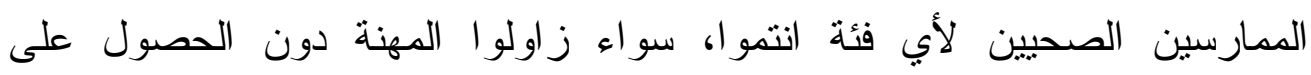

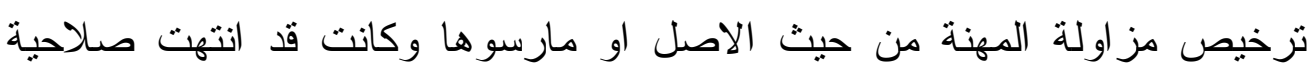
(1) الترخيص قبل تجديده.

تقديم بيانات غير مطابقة للحقيقة، او استعمال طرقاً غير مشروعة كان من نتيجتهــا

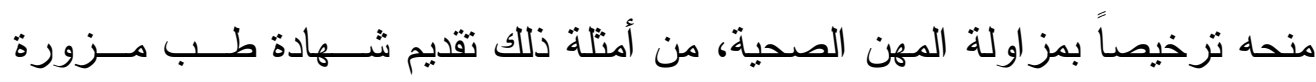
لمديرية الثؤون الصحية.

• استعمال وسيلة من وسائل الدعاية يكون من شأنها حمل الجمهور علــى الاعتقـــاد

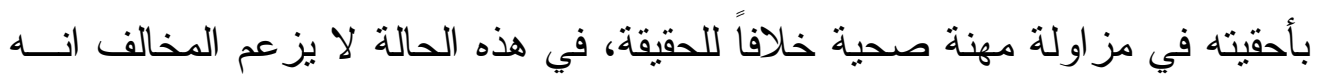

الصحية قبل عرض نص المادة Y من نظام مزاولة المهن الصحية التي نصت على الافعال

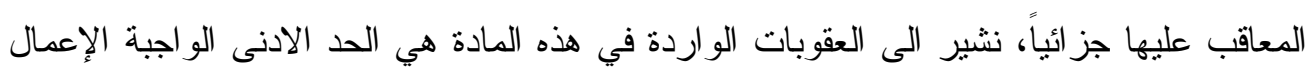
فاذا وردت عقوبة أثند في اي نظام آخر فهي التي تطبق.

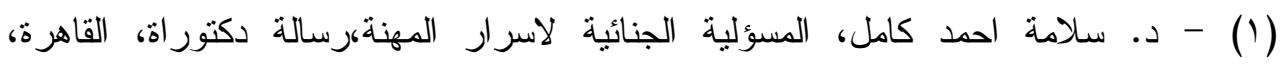
.AV صن 191. 
يمارس مهنة صحية بشكل صريح انما يلمح الى ذلك تلميحاً من خلال الدعاية لنفـسه

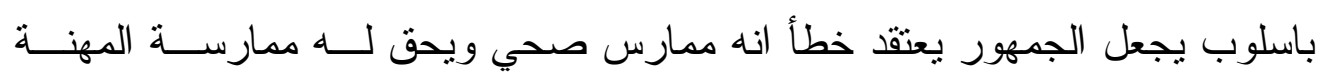

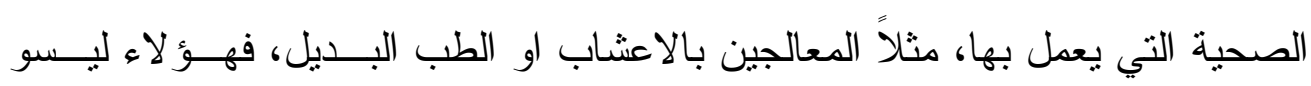

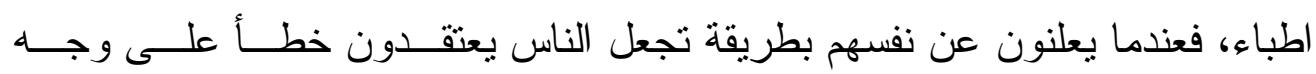
مشروع انهم اطباء تتحقق هذه الحالة ويستحق الفاعل العقاب المقرر . لعن • انتحال لنفسه لقباً من الالقاب التي تطلق عادة على مز اولي المهن الصحية، كمـن يطلق على نفسه لقب صيدلي او طبيب وهو ما زال على مقاعد الدراسة و الانتحــال

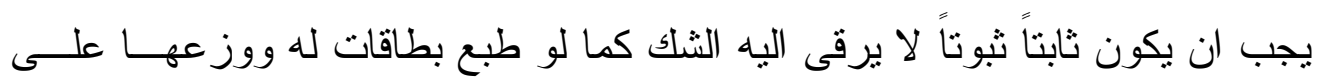

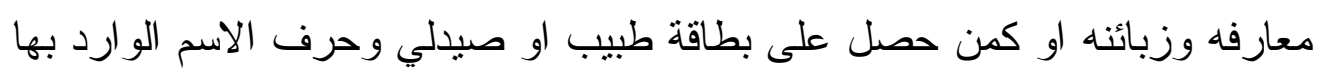
وجعلها باسمه، اما مجرد اللقب الثفوي المتعارف عليه بين اصحابه و اقاربه و الـــي ولـي

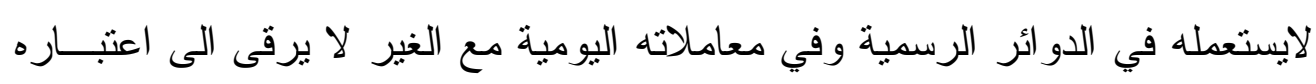
انتحال صفة)(1)

وجود لدى الممارس الصحي الات ومعدات مما يستعمل عادة فـــي مز اولـــة المهــن

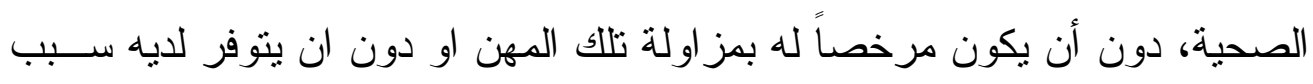
مشروع لحيازتها، كمن يكون لديه معدات لتركيب الدو اء دون ان يكون صــيدلانياً او

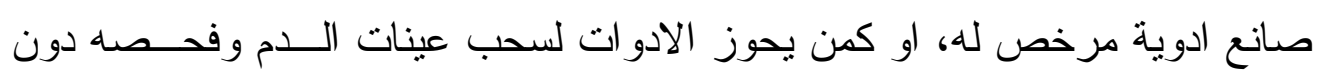
الحصول على اذن مز اولة مهنة فني مختبر •

امتتاع عن معالجة مريض دون مبرر، فاذا لم يكن للطبيب او الممارس الصحي

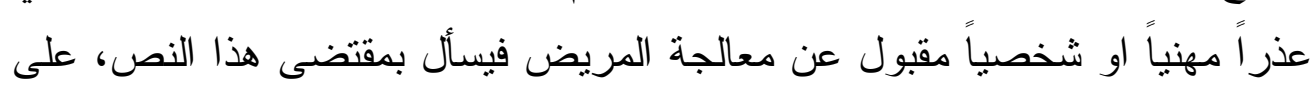
انه لا يقبل اي عذر اذا كانت حالة المريض خطره غير قابلة لتأخير العلاج. V. ممارسة طرق التشخيص و العلاج غير المعترف بها علمياً، او المحظورة في (1) د. سلامة احمد كامل، المسؤلية الجنائية لاسرار المهنة،رسالة دكتوراة، القاهرة، .91 (9،ص 
المملكة.

^. كل عمل طبي لا يستهدف مصلحة المريض، وكل ممارس تجــاوز فـي عملــــ اختصاصها او امكانياته.

عدم التبليغ عن مريض مشتبه في اصابته جنائياً او بمرض معد للجهات الامنية او الصحية.

• 1. استخدام الممارس الصحي اشخاصاً غير مرخص لهم بمزاولة المهنة، او تقديم مساعدة لاي شخص يمارس مهنة صحية بصورة غير مشروعة، او استخدام اجهزة كثف او علاجات محظورة في المملكة. ا ا. اجر اء عمل طبي دون رضى المريض او ولي امره حسب الاحوال مع مر اعاة الاسنتناءات الخاصة التي لا تتطلب الرضى. از هاق رو ح مريض ميؤوس من شفائه ولو كان بناء لطلبه.

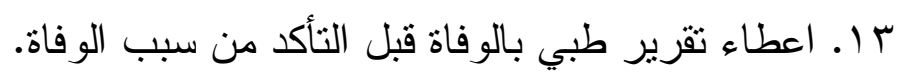

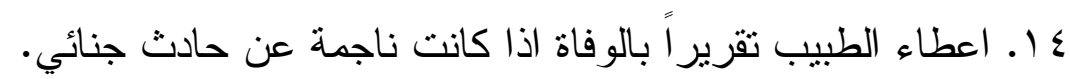
1 ـ قيام الطبيب باجهاض امر أة دون مر اعاة احكام نظام مز اولة المهن الصحية. 1 ا ـ جميع المحظور ات المتعلقة حصر اً بالصيادلة المذكورة سابقاً. مخالفة و اجبات الزمالة.

1 1. اجر اء العمليات الجراحية التجريبية وغير المسبوقة على الانسان بالمخالفة للقو اعد المنظمة لذلك.

9 1. الاتجار بالاعضاء البشرية او القيام بعملية زر اعة عضو بشري مع علمه بانـــه تم الحصول عليه عن طريق المتاجرة. هناك مخالفات اخرى نص عليها نظام مز اولة المهن الصحية عقوبتها غر امة لا تزيد على خمسين الف ريال في الحالات التالية: ا-الاعلان عن نفسه و الدعاية لشخصه مباشرة او بالواسطة، خارج الحالات الذي

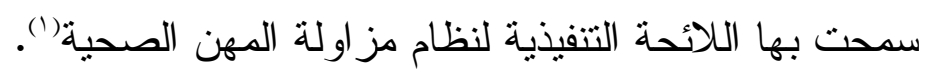

(1) د. احمد شفقة، مسؤلية الاطباء المدنية، مطبعة المكتبة الامنية، الرباط، 9199 1، ص VY I . 
r-قيام الممارس الصحي بالتسجيل على اللوحات او البطاقات او الوصفات الطبية او الاعلانا القاباً علمية او تخصصات لم يحصل عليها وفقاً للقو اعد المنظمة لها. ب-ممارسة اكثر من مهنة صحية، او ممارسة مهنة يتعارض مز اولتها مع المهنة

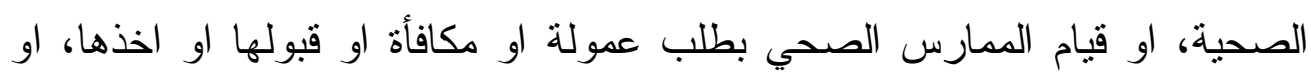
حصوله على اي منفعة لقاء الترويج او الالتزام بوصف ادوية او اجهزة او توجيه المرضى الى صبدلية معينة اومستشفى او مختبر محدد او ما في حكم ذلك. ع -اجر اء الممارس الصحي الفحوص او العلاج بالمقابل او بالمجان في الــصيدليات او الاماكن غير المخصصة لذلك. الاحتفاظ في مقر العمل بالادوية و اللقاحات خلافاً لما تسمح به تعليمات الوزارة باستثناء الصبدليات. 0- بيع الادوية للمرضى او بيع العينات الطبية لهم. باءل 7- نسهيل حصول المريض على اية ميزة او فائدة مادية او عضوية غير مستحقة

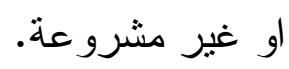
V-ايو اء المرضى في الاماكن غير المعدة لهم.

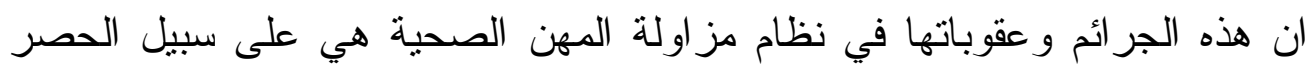

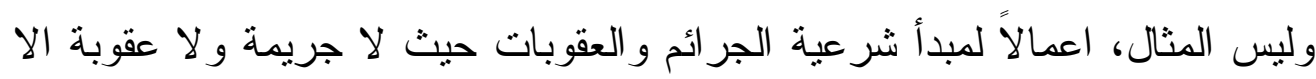
بنص. بالاضافة الى ذلك عاقب نظام مز اولة المهن الصحية بغر امة لانتزيد عـن عـشرين

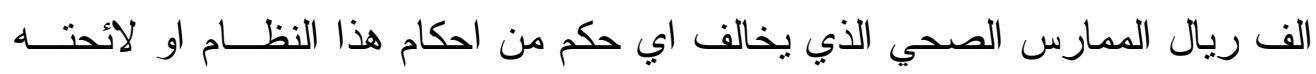
التتفيذية لم يحدد له عقوبة. 


\section{الملمب الثاني

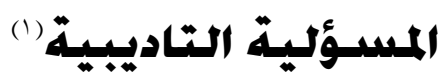

المسؤولية التأديبية للممارسين الصحيين. المسؤولية التأديبية للممارسين الصحيين.

المسؤولية التأدييية تكون عندما يخل الممارس الصحي بسلوكه المهني ما بعد خروجاً على مقتضيات و اجبات وظيفته (r).

نستخلص من هذا النص ان المسؤولية التأديبية للممارسين الصحيين تتعقد في

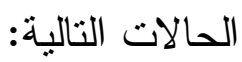

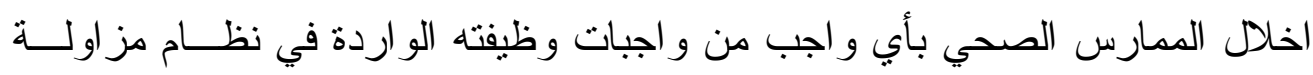
المهن الصحية او لائحته التتفيذية وتحدثتا عن هذه الو اجبات وهي و اجبــات عامـــة وو اجبات تجاه المرضى وو اجبات تجاه زملائه.

اخلال الممارس الصحي باصول مهنته، لكل عمل من الاعمال ولكل مهنة من المهن

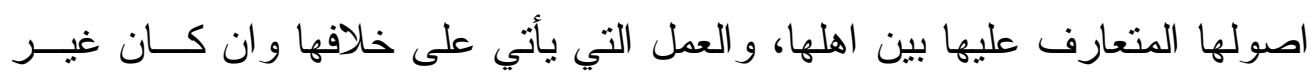

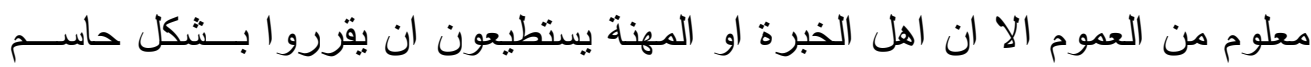
مدى اتفاق هذا النوع من العمل مع اصول المهنة من عدمه. خروج الممارس الصحي عن مقتضيات مهنته و آدابها، فكل مهنة لها رسالة يجب ان

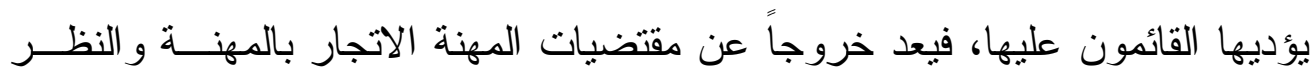
اليها على انها مورد رزق فقط دون الاهتمام بجانبها المعنوي، كما لا يجوز للقائمين

(1) د. محمد الرشيد المامون، عقد العلاج بين النظرية و التطبيق، دار النهضة القاهرة،ص VT.

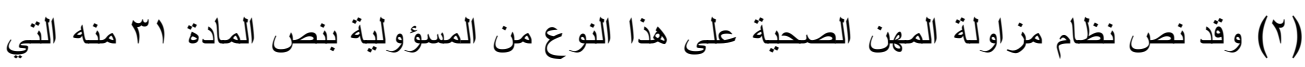

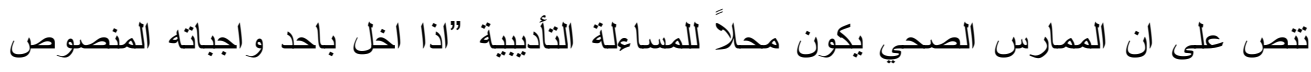

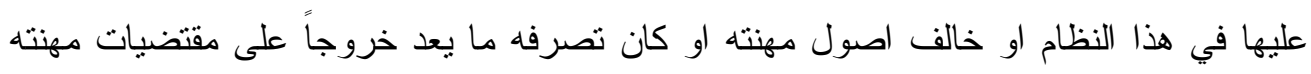
و آدابها". 
على المهن اتيان اعمال مخلة بآدابها كاستغلال الطبيب مثناً مهنته لاقامــة علاقـات غير مشرو عة مع مريضاته من النساء. العقوبات التأديبية: تتر اوح العقوبات التأدييية بحسب جسامة المخالفة، وهذه العقوبات هي:

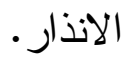

الغاء التز اخيص بمز اولة المهنة الصحية وشطب الاسم من السجل المــرخص لهــم، وفي حالة الغاء الترخيص لا يجوز التقدم بطلب ترخيص جديد الا بعد انقضاء سنتين على الأقل من تاريخ صدور قراء الألغاء.

ملاحسة مهـمـة:ان تطبيق احدى هذه الجزاءات التأديبية لا يعني اســتبعاد تطبيــق الجز اءات المدنية

(التعويض ) و الجز اءات الجنائية (سجن أو غر امة) يستفاد من ذلك من صياغة نـص

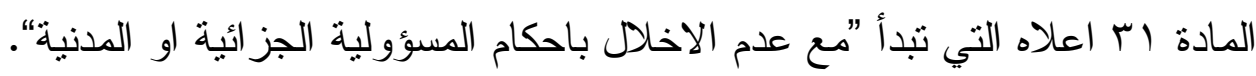
فالفعل الو احد قد يشكل سبياً لمسؤولية مدنية ومسؤولية جنائيــة ومـسؤولية تأديبيـــة للممارس الصحي في ذات الوقت.مثال ذللك قيام طبيب باجر اء تجارب طبيـــة غيــر

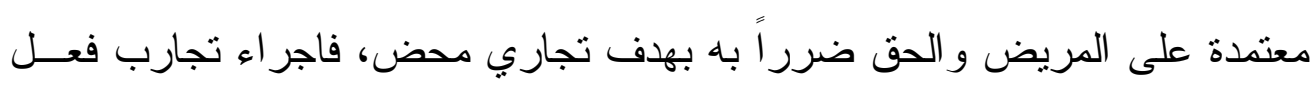
يجرمه نظام مز اولة المهن الصحية، و التسبب بضرر يحمل الطبيب مسؤولية مدنيــة، و الهدف التجاري مخالف لمقتضيات المهنة يرتب مسؤولية تأديبية.

الهيئة الصحية الثرعية (1)

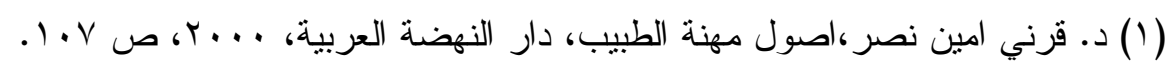




\section{المبسحشث الرابع \\ التحمقيق والماكمهة.}

اسند نظام مزاولة المهن الصحية النظر في الاخطاء المهنية الصحية التي يرتكبها الممارسون الصحيون الى هيئة اسمها "الهيئة الثرعية الصحية“، اما المخالفات الناشئة عن تطبيق هذا النظام فقد اسندها الى لجان خاصة يعينها وزير الصحية'(1). سنبحث في هذا الجزء تشكيل الهيئة، اختـصاصها، اجــر اءات المحاكمــة امامهــا، و اللجان المعينة من وزير الصحة للنظر بمخالفات نظام مزاولة المهن الصحية. تشكل الهيئة الصحية الثرعية: تتكون الهيئة الصحية الثرعية من رئيس للهيئة يكون قاض لا تقل درجته عن (أ) يعينه وزير العدل، وكل من الأعضاء: مستشار نظامي يعينه وزير العدل.

عضو هيئة تدريس من احدى كليات الطب يعينه وزير التعليم العالي، وفي المنطقـــة التي ليس فيها كلية طب، يعين الوزير بدلاً منه عضو اً من المر افق الصحية المنو افرة في تلاك المنطقة.

عضو هيئة تدريس في احدى كليات الصيدلة، يعينه وزير التعليم العالي، وفي

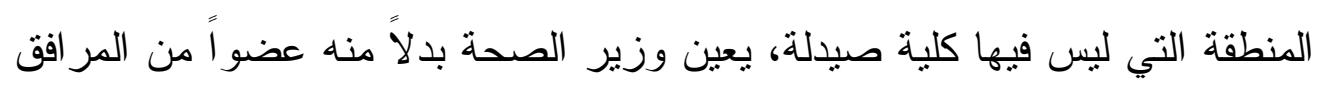
الصحية المتو افرة في تلك المنطقة. ع) طبيبان من ذوي الخبرة و الكفاية يختار هما الوزير • ๑) صيدلي من ذوي الخبرة و الكفاية، يختاره الوزير •

بالاضافة الى ذلك يجوز للهيئة الاستعانة بخبير او اكثر في موضوع القضية

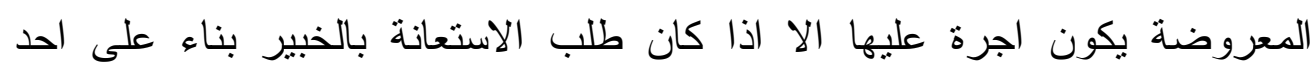
الخصوم عندها يكون اجرة على ذلك الخصم، ويجوز للوزير تعبين امين سر للهيئة

(1) د. محمد الرشيد المامون، عقد العلاج بين النظرية و التطبيق، دار النهضة القاهرة،ص V7. 
كفؤ وحاصل على مؤهل جامعي.

يقوم أمين السر بكافة الاعمال الادارية والاجر ائية المنصوص عليها بالنظام والمتعلقة

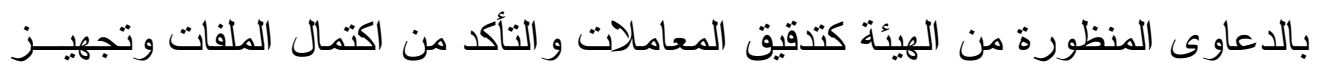
القضية وكتابة محاضر الجلسات وقرار ات الهيئة و ابلاغ اطر اف الــدعوى و اثبــات غيابهم وحضور هم. مقر الهيئة يكون بالرياض، ويجوز لوزير الصحة انشاء هيئات اخرى في المناطق يقوم هو بتحديدها. ان مدة العضوية في الهيئة هي ثلاث سنو ات قابلة للتجديد. اختصاص الهيئة الصحية الثرعية. تختص الهيئة الصحية الثرعية بالتالي: * النزاعات المتعلقة بالاخطاء المهنية الصحية التي يرفع بها مطالبة بالحق الخاص،

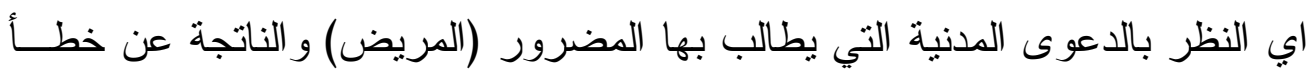
مهني صحي سو اء كانت المطالبة بالدية أي بمبلغ من المال يدفعه الممارس لأوليــاء

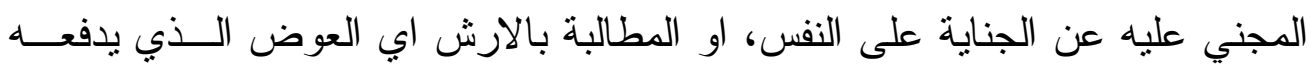
الجاني بدلاً عن الجروح، او المطالبة بالتعويض عن الضرر اللاحق بالمريض. النز اعات المتعلقة بالاخطاء المهنية الصحية الناتج عنها وفاة او تلــف عــضو مــن اعضاء الجسم او فقد منفعته او بعضها حتى ولو لم يكن هناك دعوى بالحق الخاص بلاء 


\section{المطلب الاول \\ اجـراء ات التحمقيق والمحاكمهة.}

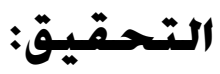

قبل رفع الدعوى من المتضرر لدى الهيئة الصحية الثرعية يجوز له او لورثته فـي حالة وفاته ان بيقدم الى المؤسسة الصحية الذي وقع فيها الخطأ او الى مدير الثؤون الصحية او لوزير الصحة بطلب التحقيق وتعتبر الثكوى من المتضرر او نائبــهـ او ورثثه بسبب الخطأ المهني الصـي مطالبته بالحق الخاص، الا انـــهـ يجـوز التقــدم بطلب التحقيق ولو لم يكن هنالك دعوى بالحق الخاص.

يتوجب على الجهة الصحية المقدم اليها الطلب او الثكوى ان تأمر باجراء التحقيق فور تقديمها من المتضرر، يجوز للمكلف بالتحقيق أن يأمر بتأجيل سفر المدعى عليهم او من يتطلب التحقيق سماع اقو الهم من ذوي علاقة او شهود حتى صدور

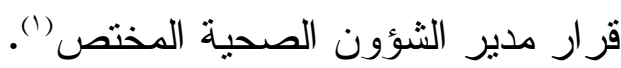

كما يجوز للمدعي بالحق الخاص ان يقدم للمحقق طلباً لرفعه الــى رئــيس الهيئــة الصحية الثرعية ضمن ملف الدعوى للنظر بمنع سفر المدعى عليه.

يتم تعيين المحقق من بين ذوي الخبرة يختارهم مدير الثؤون الصحية المختص، يتولى المحقق ابلاغ الخصوم باليوم و الساعة لمباثرة التحقيق واجر اءاته و المكان الذي يجري فيه قبل مو عد اجر اء التحقيق بوقت كاف. بوم وله

على المحقق ان يدون في محضر رسمي، البيانات الثخصية للمدعى عليه ويحيطــــ

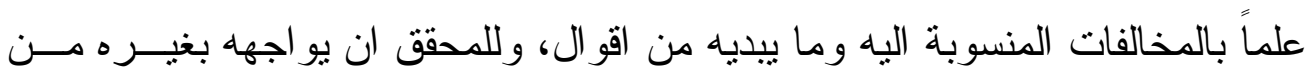
ذوي العلاقة او المدعيين او الثهود مدوناً كل اقو الهم بالمحضر ويوقع المدعى عليه على اقو اله بعد تلاوتها عليه، ويحق للخصوم اثتاء التحقيق ان يقدمو ا ما يشاؤون من

(1) د. محمد محمد محمد على، المسؤلية المدنية للصيدلي، رسالة دكتور اة، جامعة عين شمس، 
الطلبات للمحقق.

على المحقق ان يستمع الى اقوال كل من له علاقة مباشرة بالمخالفات الصحية موضوع التحقيق و الى اقو ال الثهود وله في ذلك ان يستمع الى كل شاهد على انفر اد ان يو اجهم ببعضهم وبالخصوم ويوقع كل منهم على اقو اله.

للمحققان يستعين بمن يرتئيه مناسباً من المختصين لابداء الر أي بأي مـسـألة مهنيــة

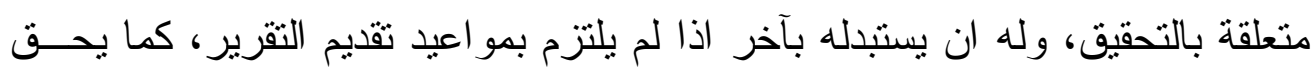

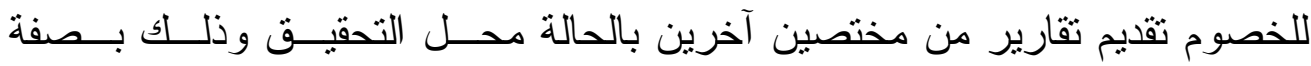
استشارية.

يجب على ذوي العلاقة تقديم جميع الاوراق و المستتدات و المفات الطبيــة و التقــارير وصور الاشعة و التحاليل الى المحقق حين بطلبها، وتعتبر جميع اجــر اءات التحقبــق ونتائجه من قبيل السر المهني على المحقق ومن يتصلون بالتحقيق او من بعلـــم بهـــا بسبب وظيفته او مهنته عدم افثائها و الا وقع تحت طائلة المسؤولية. بعد ختام التحقيق يعرض المحقق للنتائج التي توصل اليها مدعمة بالادلة والقرائن، كما يتضمن التحقيق توصية المحقق اما باحالة القضية الى الهيئة الصحية الثرعية (او لجنة المخالفات الصحية بالنسبة لمخالفات النظام) او بعدم السير في الدعوى لعدم ثبوت خطأ طبي او مخالفة تقتضي ذلك.

بعد ذلك يرفع المحقق تقرير الى مدير الثؤون الصحية المختص الذي يصدر قــراراً

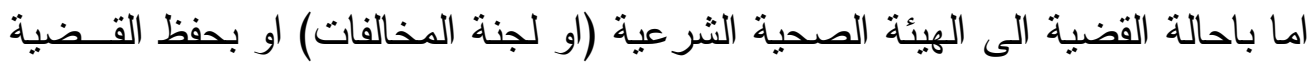
لعدم وجود خطأ طبي او مخالفة لاحكام النظام.

في هذه الحالة الأخيرة يحق لصاحب الثأن (المريض المتضرر ا نائبه او ورثثه) أن يتظلم من القرار اما امام وزير الصحة واما امام ديوان المظالم. 
عندما يكون القرار احالة القضية الى الهيئة الصحية الثرعية (او لجنة المخالفــات)، يتوجب على المحقق تسليم كافة اور اق التحقيق من مستتدات وملفات طبية الى امانـــة

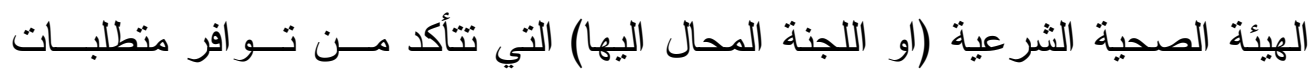

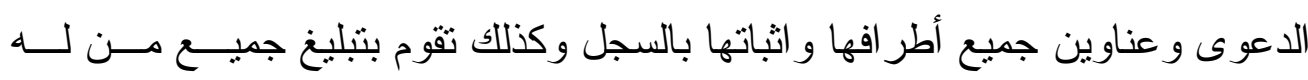

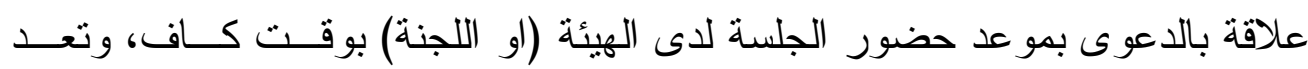
الامانة لكل قضية ملفاً خاصاً بها. اجر اءات الدعوى امام الهيئة الصحية الثرعية: اطر اف الدعوى: ككل دعوى قضائية لا بد من مدعي ومدعى عليه. المدعي بالحق الخاص: هو من لحقه ضرر فقد نصت على ذلك المادة 1 / هـ مــن اللائحة التتفيذية بالقول "على من لحقه ضرر من الخطأ الطبي ولورثته من بعــده ان

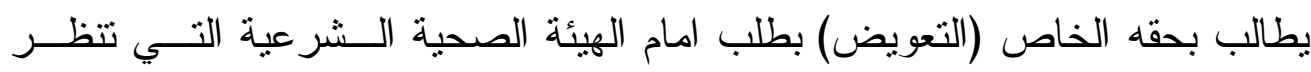

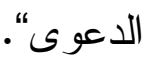

المدعي بالحق العام: يمكن ان يقدم دعوى بالحق العام امام الهيئة لانز ال العقوبات المنصوص عليها في النظام الناتجة عن ارتكاب الاخطاء المهنية، ويمثل الادعاء العام موظفون يصدر قر ار بتحديدهم من وزير الصحة. المدعى عليه: هو الممارس الصحي المتهم بارتكاب خطأ مهني، وقد بــدعى على هذا الأخير و على المؤسسة الصحية التي يعمل بها. اجر اءات الدعوى امام الهيئة الصحية الشرعية: اطر اف الدعوى: ككل دعوى قضائية لا بد من مدعي ومدعى عليه. المدعي بالحق الخاص: هو من لحقه ضرر فقد نصت على ذلك المــادة 1 / (1) د. سلامة احمد كامل،الحماية الجنائية لاسر ار المهنة، جامعة القاهرة .9191، ص 119. 
هـ من اللائحة التتفيذية بالقول "على من لحقه ضرر من الخطأ الطبي ولورثته مـن

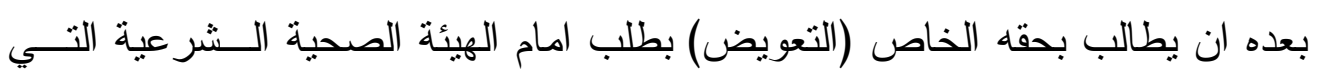

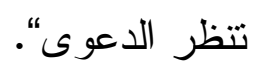

المدعي بالحق العام: يمكن ان يقدم دعوى بالحق العام امام الهيئة لانز ال العقوبات

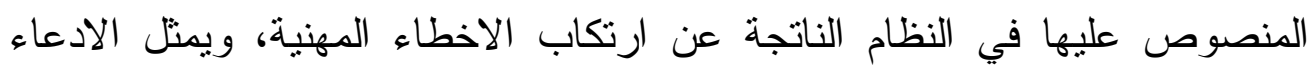
العام موظفون بصدر قر ار بتحديدهم من وزير الصحة. المدعى عليه: هو الممارس الصحي المتهم بارتكاب خطأ مهني، وقد يــدعى على هذا الأخير و على المؤسسة الصحية التي يعمل بها. تتعقد الهيئة بحضور جميع اعضائها ويحضر امين السر الجلسات ويتــولى تحريــر

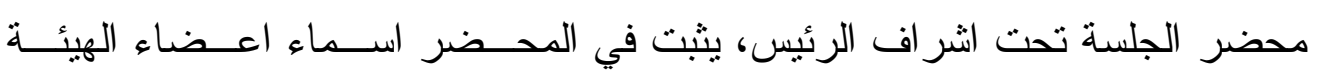

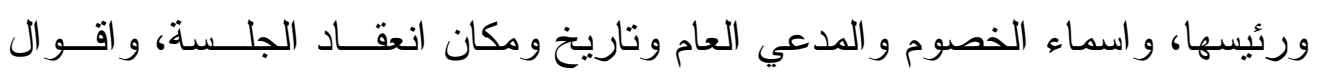

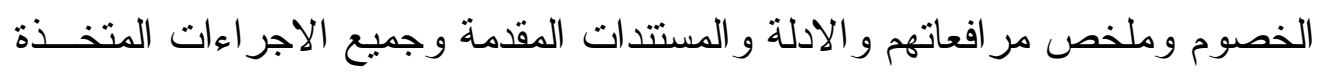
في الجلسة ويوقع المحضر رئيس الهيئة و الاعضاء على كل صفحة.

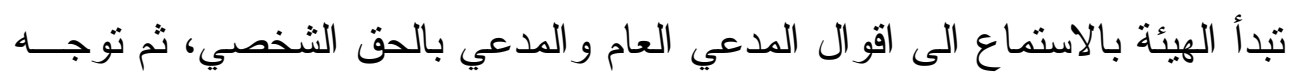

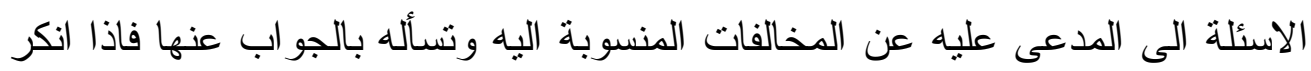

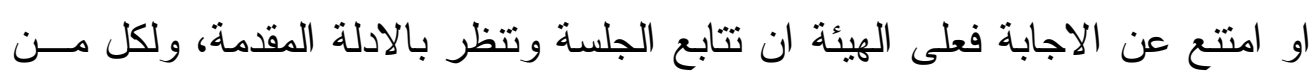

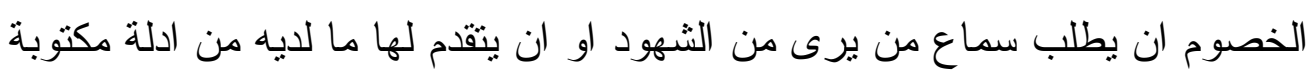
لتضمه الى ملف القضية) (1) تستمع الهيئة الى جهة الادعاء والخصوم و الثهود وتدون اقو الهم باللغة العربية فاذا كان احدهم لا يتكلم العربية فعليه الاستعانة بمترجم. للمدعي بالحق الثخصي ان يتقدم اثثاء نظر الدعوى او بعد احالتها اليها مباشرة الى الفاهة (1) د. محمد محمد محمد على، المسؤلية المدنية للصيدلي، رسالة دكتوراة، جامعة عين شمس، 
رئيس اللجنة بطلب ذات طبيعة مستعجلة لمنع خصمه من السفر .

$$
\text { قو اعد الحضور و الغياب: }
$$

يبلغ ذوو الثنأن كتابة بمكان وزمان مثولهم امام الهيئة (أو لجنة المخالفـات)

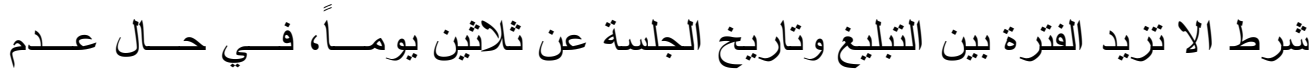

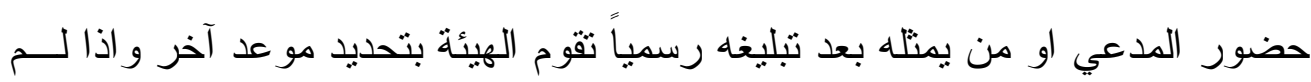

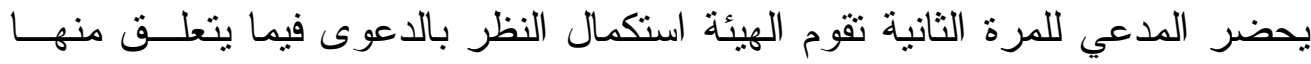
بالثق العام فقط ويصرف النظر بالثق الخاص. اما في حالة عدم حضور المدعى عليه بعد ثبليغه رسمياً، على الهيئة تأجيل الجلــسة

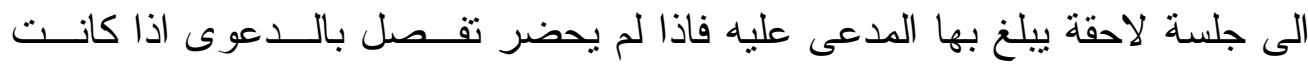
جاهزة للحكمن ويعتبر الحكم في جميع الحالات حضورياً.

و اذا كان من شأن الايقاف عن مز اولة المهنة الاضر ار بالمرضى المستقيدين فعلـى الوزير اتخاذ ما يجب لاستمر ار تلقى المرضى ما يحتاجونه من رعاية صحية ويحق للممارس الصحي التظلم من الايقاف لدى ديوان المظالم خلا ثلاثين يوماً من تاريخ ابلاغه بذلك.

التظلم ضد الاخطاء الطبية:

للأطباء و أطباء الاسنان اجباري، للممارسين الصحيين غير هؤ لاء اختياري. الزم نظام مز اولة المهن الصحية جميع الاطباء و اطباء الاسنان العاملين فـي المؤسسات الصحية و الخاصة باجر اء تأمين الزامي ضد الاخطاء المهنية الطبية لاءى

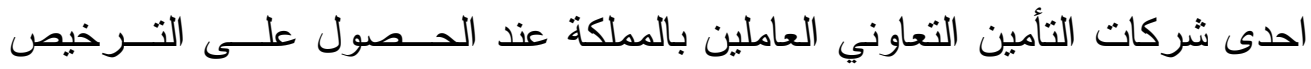
بالعمل او تجديد الترخيص.

و على الجهة ذات العلاقة (المؤسسات الصحية العامة و الخاصة) اتخاذ الاجر اء الكفيل بقيام الطبيب بالتأمين ضد الاخطاء الطبية المهنية. تشمل منـــافع التغطيـــة التأمينيـــة التعويض بالحق الخاص للمضرور الناتج عن الخطأ المهني الطبي، و اذا لم تتـــوافر 
تغطية تأمينية لسداد التعويضات، او كانت التغطية غير كافية فان المؤسسة الــصحية التابع لها الممارس الصحي سو اء كانت عامة او خاصة تكــون مـسؤولة مـسؤولية تضامنية عن سداد التعويض المحكوم به للمضرور، على ان بطالــب هــــا الاخيــر

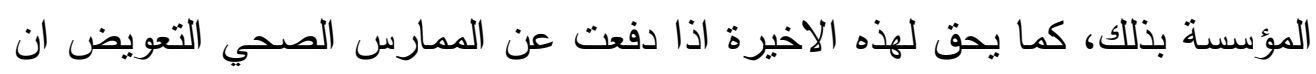
تزجع عليه بالمبلغ التي دفعته.

يمكن ان يشمل التأمين التعاوني فئات اخرى من الممارسين غير الاطبـــاء و اطبـــاء الاسنان وذلك بقرار من مجلس الوزر اء بناء على اقتر اح وزير الصحة (1).

(1) د. محمد الرشيد المامون، عقد العلاج بين النظرية و التطبيق، دار النهضة القاهرة،ص TY. 


\section{الخــــاتمة}

ومن البحث يبدو و اضحاً أن لكل مرحلة خصائصها المميزة و التي تعكـس التطــور الملموس للخدمات الصحية في المملكة عامة و الرياض خاصة مع زيادة المخصصات

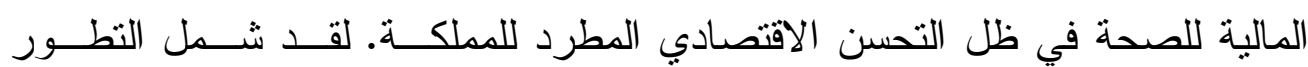

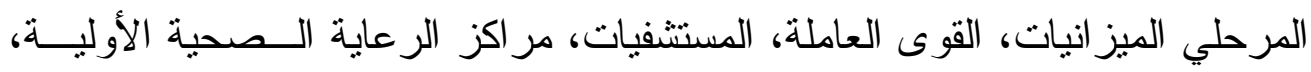

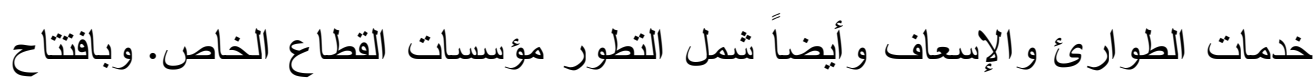
مدينة الملك فهد الطبية تكون الرياض قد وصلت إلى مستوى عــال مــن الخـدمات

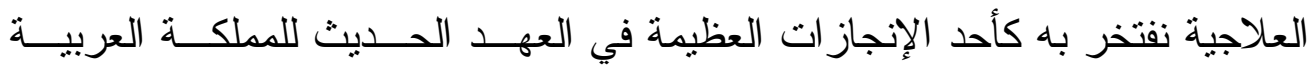
السعودية.

وفي الختام إن ما أنجز في المجال الصحي بالمملكة عامة ومنطقة الريــاض خاصـــة

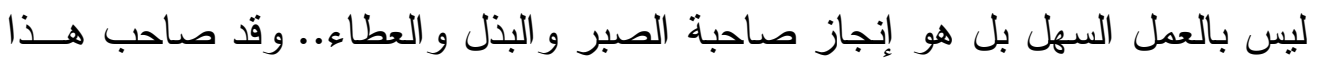

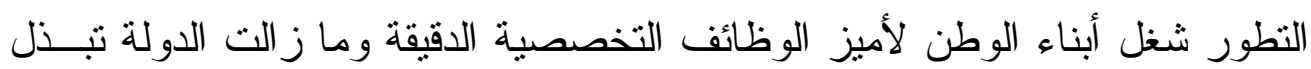
قصارى جهدها في مجال التدريب و إنثاء المؤسسات الصحية الحديثة التي يقع علـى لـى

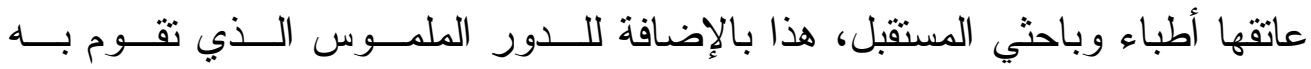

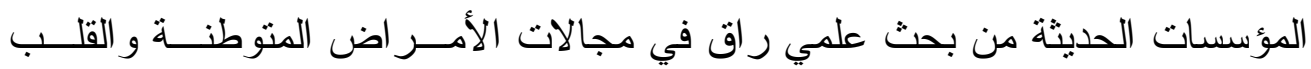
و السرطان على سبيل المثنال لا الحصر. سيظل تطور الخدمات الصحية ديدناً حتى ينعم المو اطن الــسعودي بالمـسـتوى

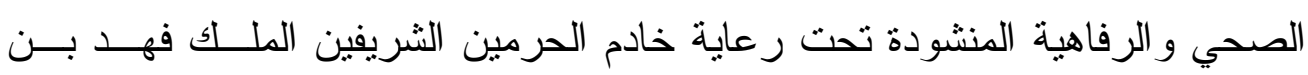
عبدالعزيز وحكومته الرشيدة. 


\section{النـتائج}

من خلال عرض ومناقتة البيانات السابقة فقد توصل الباحث إلى الاستتناجات

التالية: - م

ا. . مستوى وعي المستفيدين في المملكة العربية السعودية بالنظام الصحي التعاوني بشكل عام هو مستوى منخفض.

r. درجة الإدر الك لدى مقدمي الخدمات الصحية في المملكة العربية السعودية بشكل عام هى درجة منوسطة.

ץ. وجود فروق ذات دلالة إحصائية بين مسنوى وعي كل من المستقيدين ومقـدمي الخدمات الصحية بالمملكة.

وهى تؤكد النتيجة السابقة التى تشير ان مستوى وعي المستفيدين بالخدمات الصحية بالمملكة هو مسنوى (منخفض) بينمامستوى وعى مقدمي الخدمات الصحية بالمملكة هو مستوى (متوسط) ع. الانعكاسات الاجتماعية و الاقتصادية المتوقعة من نطبيق نظام صحي عالي الجودة في المملكة العربية السعودية بشكل عام هى انعكاسات ذات مستوى عال.

التوصيات:

بناءاً على نتائج الدراسة الميدانية التي أجريت لاستطلاع آر اء المستفيدين من النظام الصحي، وكذللك التعرف على آراء الذين سيقومون على تتفيذه من المستشفيات وشركات التأمين العاملة بالمملكة، و على التحليل الذي تم للتعرف على مكونات هذا النظام، يمكن الخروج بالتوصيات التالية: ا. ضرورة تكثثف الجهود التقيفية التي تقوم بها وزارة الصحة و الجهات الأخرى المعنية بتطبيق نظام صحي عالي الجودة لتوفير الوعي المناسب لدى المجتمع 
السعودي بأهمية العناية بالصحة و بالعاملين في مختلف الخدمات الصحية بالمملكة وتوضيح المز ايا النسبية التي يحققها المجتمع السعودي عموما من تطبيقه. r. ضرورة الاستفادة من جهود هيئة كبار علماء المسلمين و أساتذة الـشريعة فـي المعاهد و الجامعات السعودية وأئعة المساجد لتوضيح الأبعاد الثر عية لالتز ام العاملين بالمجال الصحي بالالتز ام بالضمير الحي ليكون النظام الصحي التعاوني عالي الجودة لكل شر ائح المجتمع.

r. ضرورة تفعيل دور الجهات المشرفة على النظام الصحي و إنشاء آلية لمر اقبة ضمان جودة الخدمات الصحية.

ع. ضرورة تفعيل دور الهيئة المشرفة على تطبيق نظام صحي عالي الجودة. ๑. البدء في تدريب الكو ادر البشرية اللازمة لتطبيق نظام صحي عالي الجودة. 7. ضرورة وضع الخطط التي تساهم في تحسين مستوى الخدمات الصحية وتحسين مستوى رضا المستقيدين حول الخدمات الصحية التي يشتركون فيها أو المقدمة لهم. 


\section{$8,1,1$}

( ) ابن ثثيان، سليمان (199 (1 ) ): التأمين و أحكامه. بيروت، دار العو اصم المتحدة للنشر

ץ) (بن سعيد، خالد (99191م ): ((العو امل المؤثرة على أقساط التأمين الصحي ))، ندوة التأمين الصحي و الضمان الصحي التي عقدها مجلس التعاون لدول الخليج

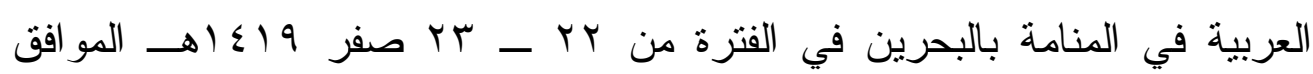

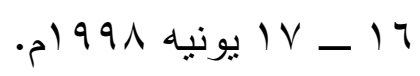

r) (ابن سعيد، خالد ( (. . rم ): التأمين الصحي التعاوني. الرياض، جامعة الملك سعود.

ع) ابن سعيد، خالد وبدران العمر (799 (م ) ): ((تجارب عالمية مختارة في التأمين الصحي ))، ورقة مُقدَّمة لندوة تقديم وتمويل الخدمات الصحية بين مسئوليات الدولة

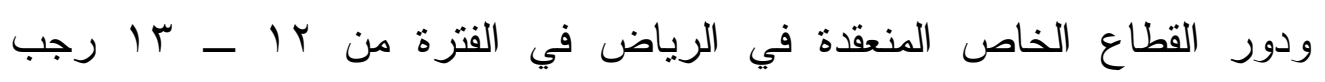

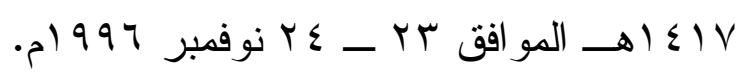

0) أبو السعود، رمضان ( . . rم ): أصول التأمين. الإسكندرية، دار المطبوعات الجامعية.

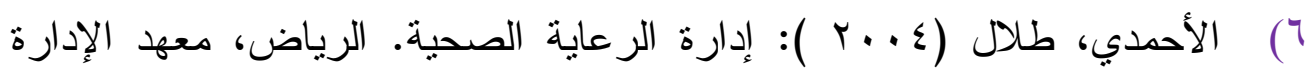
العامة.

V أخضر، فاروق (990 (م ) ): تخصيص الاقتصاد السعودي بين النظرية و التطبيق. جدة، الشركة السعودية للأبحاث و النشر .

^) آل محمود، عبداللطيف (ع99 (م ): التأمين الاجتماعي في ضوء الثريعة الإسلامية. بيروت، دار النفائس للنشر • 


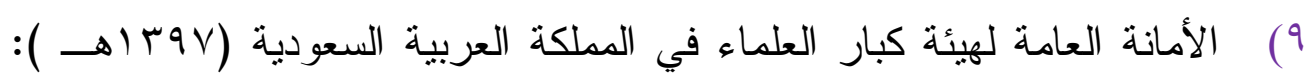

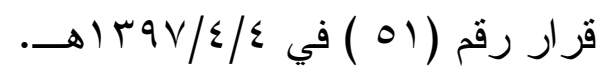

• () باز ، علاء(• ( • ( )، دالة الإنتاج في القطاع الصحي السعودي، رسالة ماجستير غير منشورة مقدمة لقسم الاقتصاد، كلية إدارة الأعمال، جامعة الملك سعود.

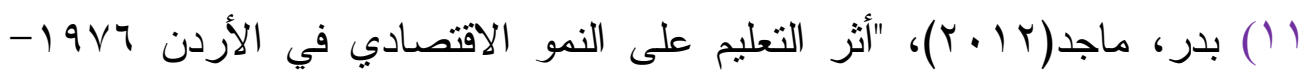

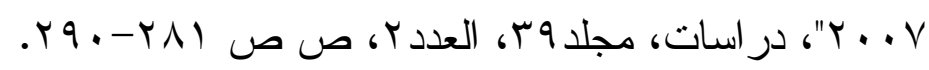

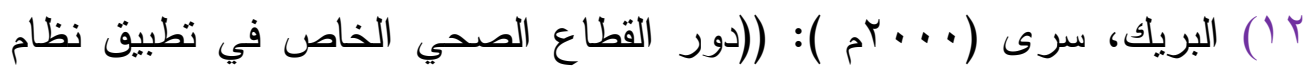
الضمان الصحي التعاوني ))، ورقة مُقدَّة في ندوة الضمان الصحي التعاوني

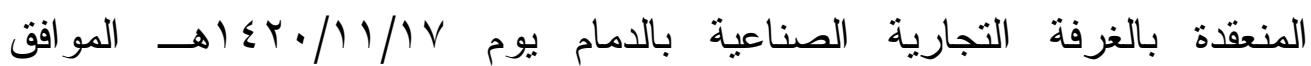
.

r ( ) البنك الدولي، مؤشر ات التتمية العالمية، قاعدة البيانات على الإنترنت. § () بيت الباحث العربي (1) (هـ ) ): التأمين التعاوني في المملكة العربية السعودية، الو اقع و المشكلات و الآفاق المستقبلية. الرياض.

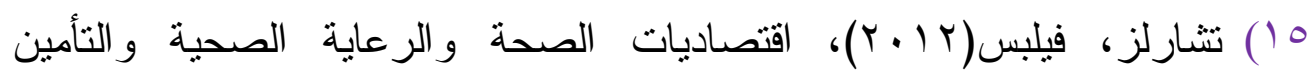
الصحي: المسار الأمريكي، المكتب العربي الحديث.

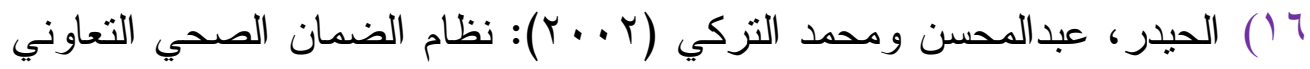
في المملكة العربية السعودية ((بحث ميداني )) الرياض معهد الإدارة العامة.

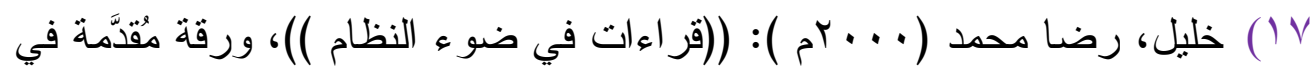

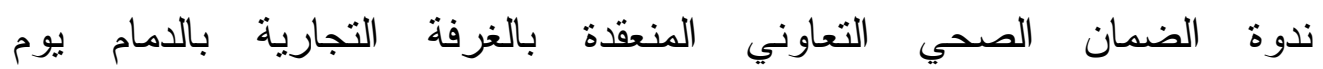

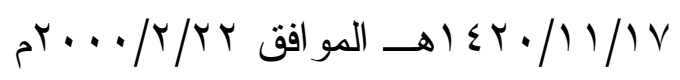




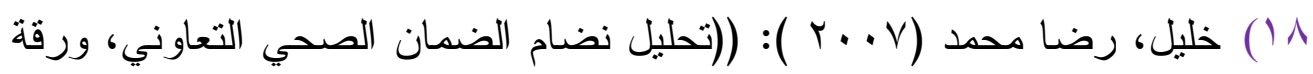
مقدمة في ندوة الضمان الصحي التعاوني المنعقدة بقاعة شاطئ لاكوستا بجدة يوم

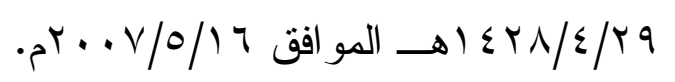

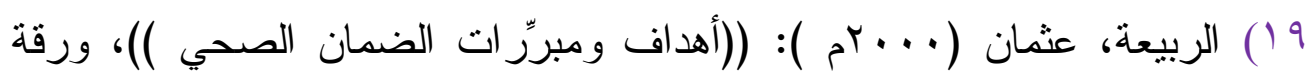
مُقدَّمة في ندوة الضمان الصحي التعاوني المنعقدة بالغرفة التجارية بالدمام يوم

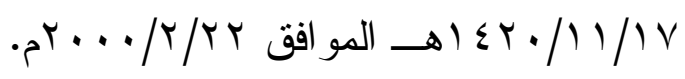

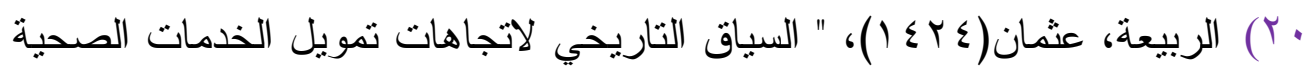
في المملكة وتوجهات المستقبل"، السلسلة العلمية لجمعية الاقتصاد السعودية، مجلده، العدد 9.

(ץ) ساعاتي، عبدالإله (991 19 ): ((تطبيق نظام الضمان الصحي في دول مجلس

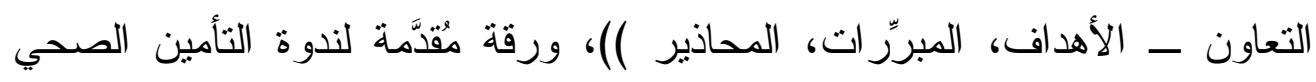

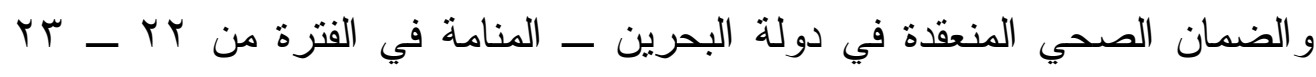

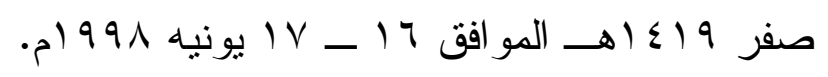

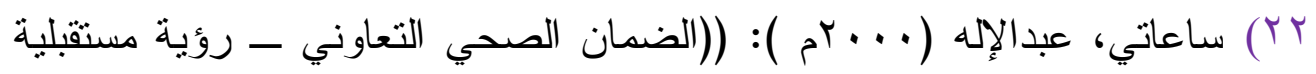
))، ورقة مُقََّّة في ندوة الضمان الصحي التعاوني المنعقدة بالغرفة التجارية

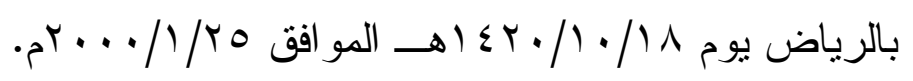

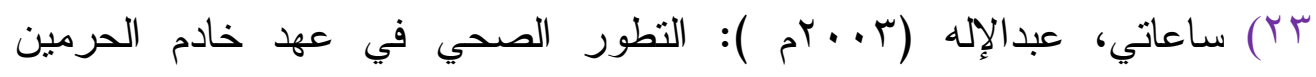
الشريفين حضارة و إنجاز • جدة، السعودية للتأمين.

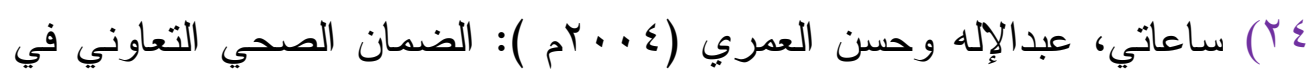
المملكة العربية السعودية بين النظرية و النطبيق. جدة، مطبعة المحمودية.

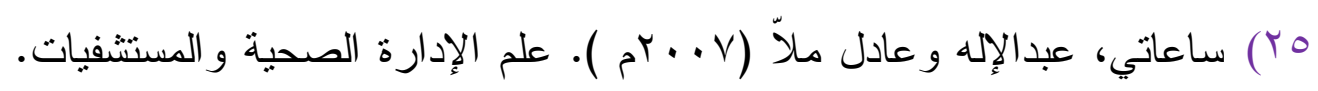
جدة، جامعة الملك عبدالعزيز • 


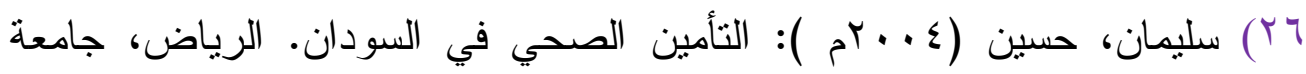
الملك سعود.

YV

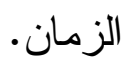

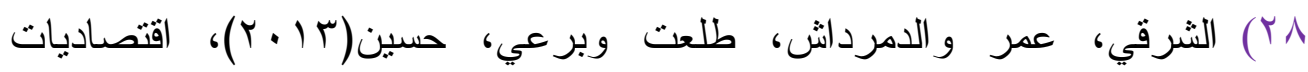
الخدمات الصحية: إثـارة إلى اقتصاديات النظام الصحي السعودي، خوارزم العلمية.

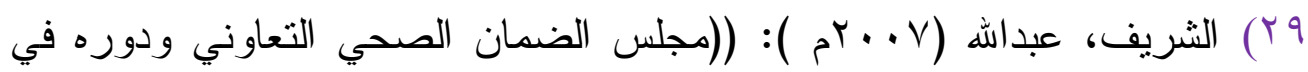
تطبيق النظام ))، ورقة عمل مقدمة في ندوة الضمان الصحي المنعقدة في الرياض

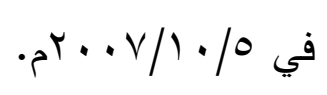

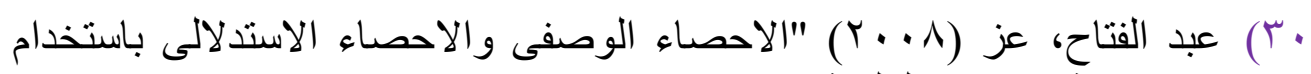
" مPSS

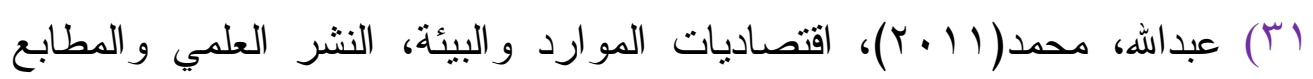
جامعة الملك سعود.

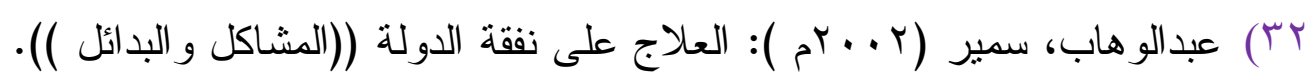

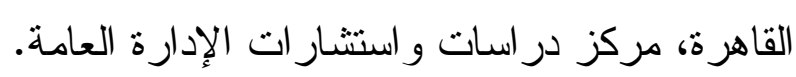

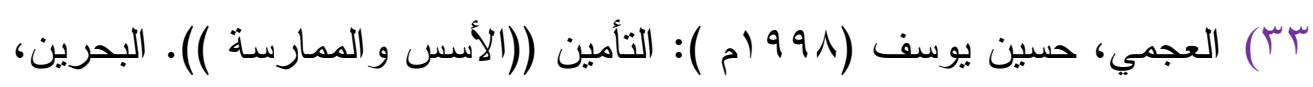
معهد البحرين للار اسات المصرفية. §ץ) العساف، صالح بن محمد (990 (م ): المدخل إلى البحث في العلوم السلوكية. الرياض، العبيكان للنشر و التوزيع و الطباعة.

هץ) عطية، عبدالقادر (990 (م ): اتجاهات حديثة في التنمية. الإسكندرية، دار المطبو عات الجامعية.

بr) الغز الي، طارق (r + •rم ): العلاج على نفقة الدولة. القاهرة، مركز دراسات و استشار ات الإدارة العامة. 
( الفقبه، محمد (991 (م )): ((كيف نستطيع تقديم خدمات صحية جيدة ؟ دور الضمان و التأمين من وجهة نظر طبيب ممارس ))، ورقة مُقدَّة لندوة التأمين

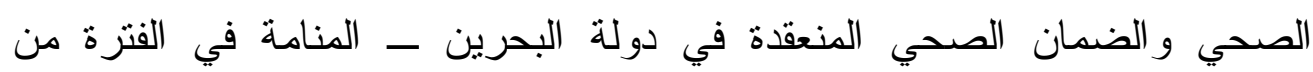

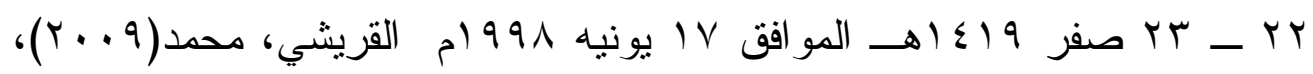
علم اقتصاد التتمية، إثر اء للنشر و التوزيع.

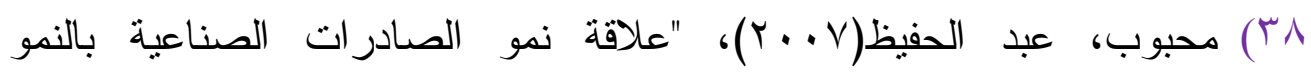

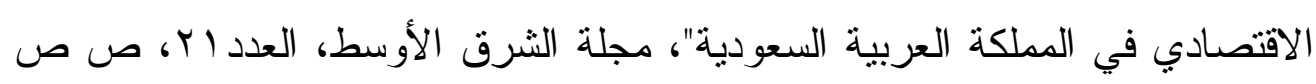
. $\leqslant\{7-\varepsilon r$.

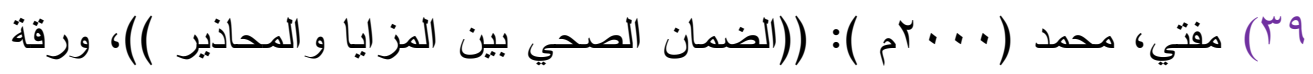
مُقدَّمَة في ندوة الضمان الصحي التعاوني المنعقدة بالغرفة التجارية بالدمام يوم

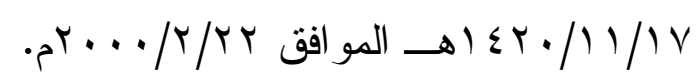

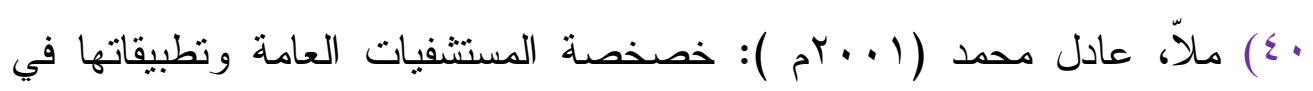
المملكة العربية السعودية. جدة، مطبعة الخطوط السعودية. (؟) منظمة الصحة العالمية، تقارير سنوية متعددة. Y Y ) مؤسسة النقد العربي السعودي، تقارير متعددة.

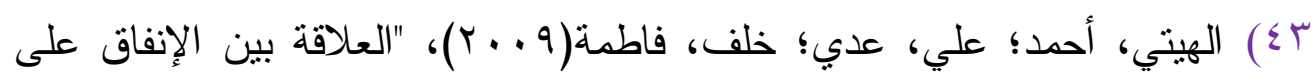
الصحة و التعليم والنمو الاقتصادي: دراسة تحليلية في كل من الاقتصاد الأردني

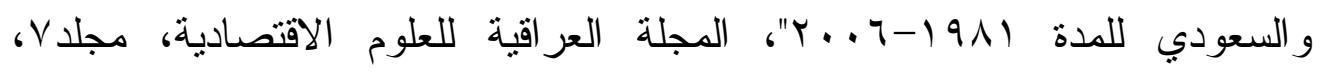

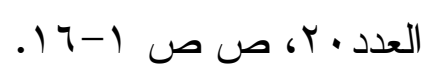

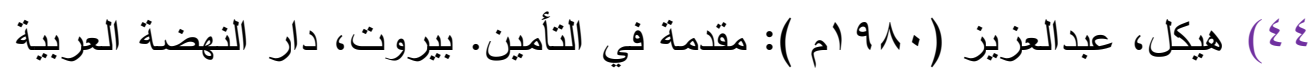
للنشر

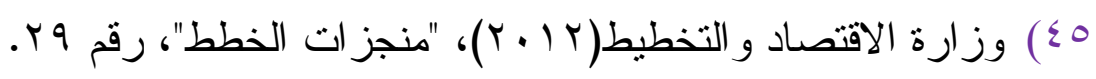




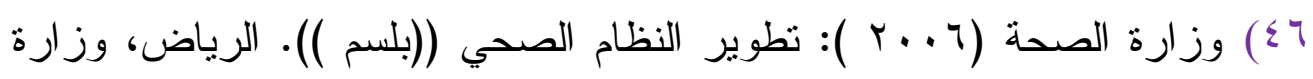
الصحة.

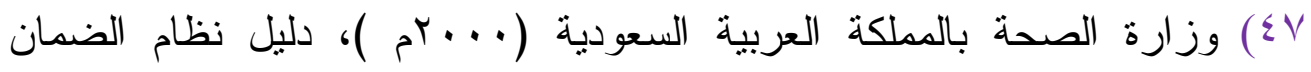
الصحي التعاوني.

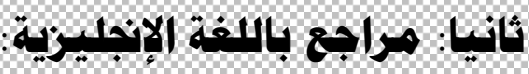

1) R.Reich, Michael1990), "The politics of health sector reform in developing countries: three cases of pharmaceutical policy", Health Policy,vol.rr, no. ', pp.. $\vee-\varepsilon \vee$ 